Prepared in cooperation with the Imperial Irrigation District

Final Report: Baseline Selenium Monitoring of Agricultural Drains Operated by the Imperial Irrigation District in the Salton Sea Basin, California

Open-File Report 2010-1064 



\section{Final Report: Baseline Selenium Monitoring of Agricultural Drains Operated by the Imperial Irrigation District in the Salton Sea Basin, California}

By Michael K. Saiki, Barbara A. Martin, and Thomas W. May

Prepared in cooperation with the Imperial Irrigation District

Open-File Report 2010-1064

U.S. Department of the Interior

U.S. Geological Survey 


\section{U.S. Department of the Interior \\ KEN SALAZAR, Secretary}

\section{U.S. Geological Survey \\ Marcia K. McNutt, Director}

U.S. Geological Survey, Reston, Virginia: 2010

For more information on the USGS-the Federal source for science about the Earth, its natural and living resources, natural hazards, and the environment, visit http://www.usgs.gov or call 1-888-ASK-USGS.

For an overview of USGS information products, including maps, imagery, and publications, visit http://www.usgs.gov/pubprod

To order this and other USGS information products, visit http://store.usgs.gov

Suggested citation:

Saiki, M.K., Martin, B.A., and May, T.W., 2010, Final report: Baseline selenium monitoring of agricultural drains operated by the Imperial Irrigation District in the Salton Sea Basin: U.S. Geological Survey Open-File Report 2010-1064, 100 p.

Any use of trade, product, or firm names is for descriptive purposes only and does not imply endorsement by the U.S. Government.

Although this report is in the public domain, permission must be secured from the individual copyright owners to reproduce any copyrighted material contained within this report. 


\section{Contents}

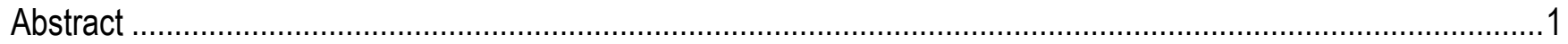

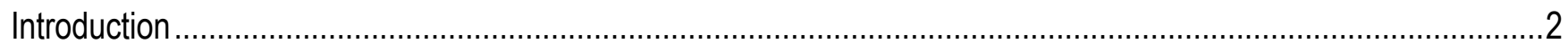

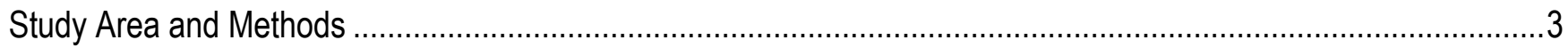

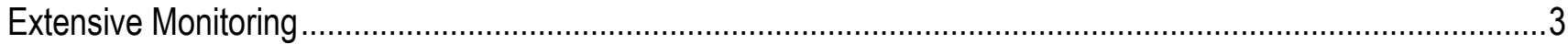

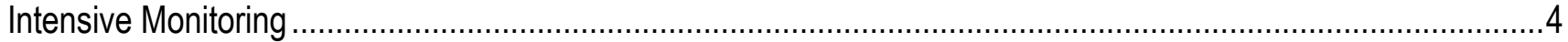

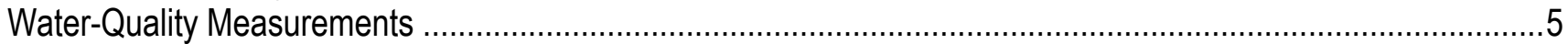

Fish Species Composition and Abundance .........................................................................................

Collection of Samples for Selenium and Other Determinations.................................................................

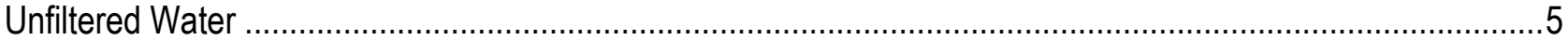

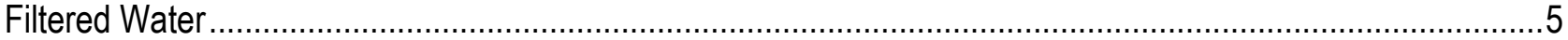

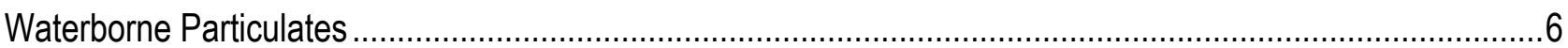

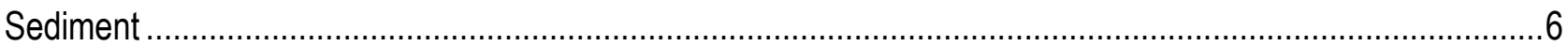

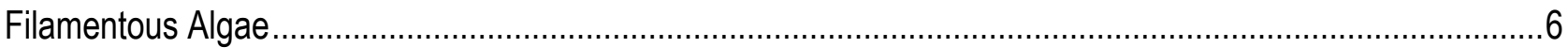

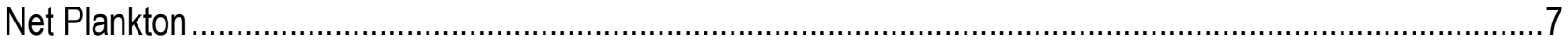

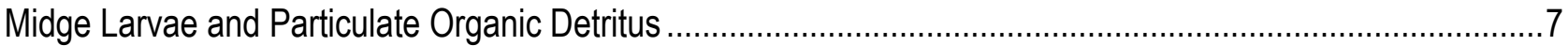

Fish

Quality Control for Selenium and Other Chemical Determinations...........................................................

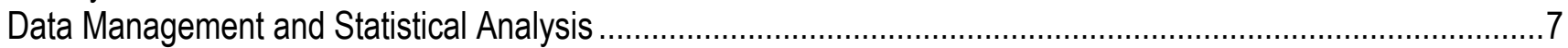

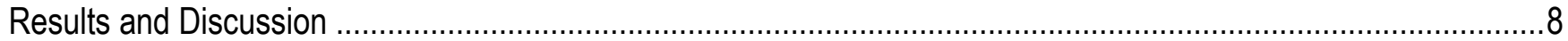

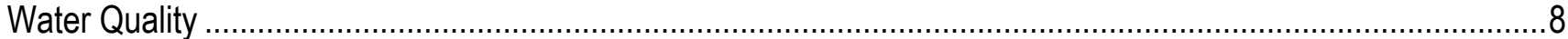

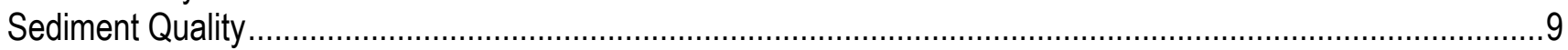

Relation between Selenium in Sediment and Waterborne Selenium ........................................................10

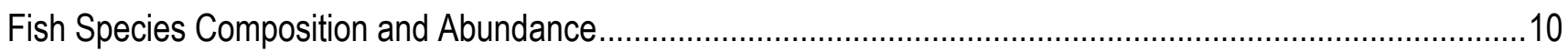

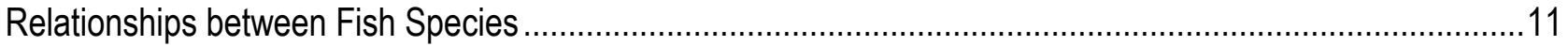

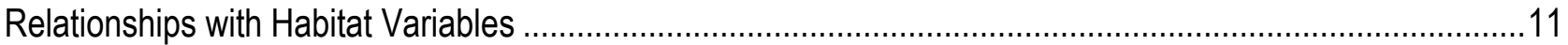

Selenium Concentrations in Water, Sediment, Aquatic Food Chain Matrices, and Surrogate Fish Species ........12

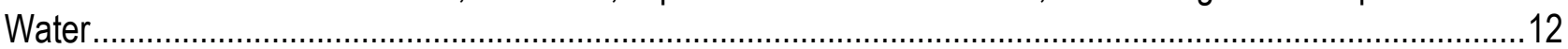

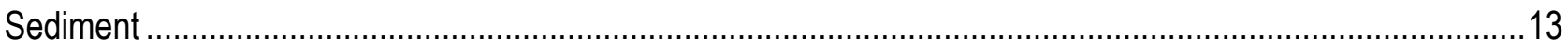

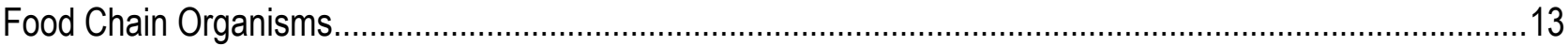

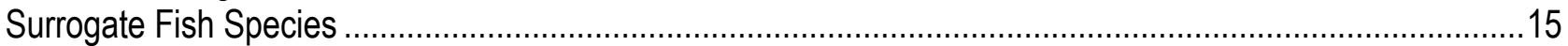

General Patterns of Selenium Bioaccumulation ........................................................................................... 15

Relation of Measured Selenium Concentrations to Proposed Toxicity Thresholds .........................................17

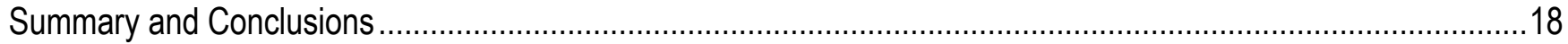

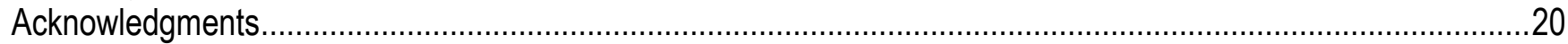

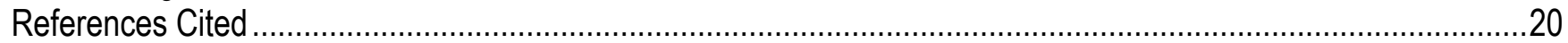




\section{Figures}

Figure 1. Map of the study area showing locations of 29 agricultural drains and ponds selected for extensive monitoring.

Figure 2. Boxplots of temperature in water from 29 agricultural drains or ponds measured on 16 sampling dates from July 2005 to April 2009. 24

Figure 3. Boxplots of dissolved oxygen concentration in water from 29 agricultural drains or ponds measured on 16 sampling dates from July 2005 to April 2009 25

Figure 4. Boxplots of hydrogen-ion concentration $(\mathrm{pH})$ in water from 29 agricultural drains or ponds measured on 16 sampling dates from July 2005 to April 2009 26

Figure 5. Boxplots of salinity concentration in water from 29 agricultural drains or ponds measured on 16 sampling dates from July 2005 to April 2009

Figure 6. Boxplots of turbidity in water from 29 agricultural drains or ponds measured on 16 sampling dates from July 2005 to April 2009

Figure 7. Boxplots of total suspended solids (TSS) concentration in water from 29 agricultural drains or ponds measured on 16 sampling dates from July 2005 to April 2009 .....

Figure 8. Boxplots of total selenium concentration in unfiltered water samples from 29 agricultural drains or ponds measured on 16 sampling dates from July 2005 to April 2009.

Figure 9. Dendrogram for cluster analysis (Ward's minimum-variance method) based on geometric mean values of total selenium concentrations in unfiltered water samples from 29 agricultural drains or ponds sampled on 16 sampling dates from July 2005 to April 2009 31

Figure 10. Graphs of (a) the cubic clustering criterion (CCC) and (b) the pseudo t2 (PST2) statistic..................... 32 Figure 11. Graph of relation of semipartial $R^{2}$ (SPRSQ) statistics and number of clusters for total selenium concentrations in unfiltered water samples

Figure 12. Boxplots of temperature in water measured on 16 sampling dates from 29 agricultural drains or ponds

Figure 13. Boxplots of dissolved oxygen concentration in water measured on 16 sampling dates from 29 agricultural drains or ponds. Symbols are geometric means (+), 95\% confidence intervals (box), and minimum and maximum values (vertical lines).

Figure 14. Boxplots of hydrogen-ion concentration $(\mathrm{pH})$ in water measured on 16 sampling dates from 29 agricultural drains or ponds.

Figure 15. Boxplots of salinity concentration in water measured on 16 sampling dates from 29 agricultural drains or ponds. Symbols are geometric means (+), $95 \%$ confidence intervals (box), and minimum and maximum values (vertical lines). 37

Figure 16. Boxplots of turbidity in water measured on 16 sampling dates from 29 agricultural drains or ponds ..... 38 Figure 17. Boxplots of total suspended-solids concentration in water measured on 16 sampling dates from 29 agricultural drains or ponds. Symbols are geometric means (+), $95 \%$ confidence intervals (box), and minimum and maximum values (vertical lines).

Figure 18. Boxplots of total selenium concentration in water measured on 16 sampling dates from 29 agricultural drains or ponds.

Figure 19. Graph showing particle-size distribution of sediment samples from 29 agricultural drains or ponds collected between April 2006 and April 2009 .

Figure 20. Boxplots of temperature in sediment samples from 29 agricultural drains and ponds collected during April 2006, April 2007, April 2008, and April 2009. 


\section{Figures-Continued}

Figure 21. Boxplots of hydrogen-ion concentration $(\mathrm{pH})$ in sediment samples from 29 agricultural drains and ponds collected during April 2006, April 2007, April 2008, and April 2009

Figure 22. Boxplots of oxidation-reduction potential in sediment samples from 29 agricultural drains and ponds collected during April 2006, April 2007, April 2008, and April 2009.

Figure 23. Boxplots of Schoklitsch $\mathbf{s}$ (also referred to as "particle-size distribution index") in sediment samples from 29 agricultural drains and ponds collected during April 2006, April 2007, April 2008, and April 2009

Figure 24. Boxplots of total selenium concentration in sediment samples from 29 agricultural drains and ponds collected during April 2006, April 2007, April 2008, and April 2009.

Figure 25. Boxplots of total organic carbon content in sediment samples from 29 agricultural drains and ponds collected during April 2006, April 2007, April 2008, and April 2009.

Figure 26. Boxplots of temperature in sediment samples collected on seven sampling dates from agricultural drains: Trifolium 20, Poe, Trifolium 18, Trifolium 14, 0, T, and Z-Spill.

Figure 27. Boxplots of hydrogen-ion concentration $(\mathrm{pH})$ in sediment samples collected on seven sampling dates from agricultural drains: Trifolium 20, Poe, Trifolium 18, Trifolium 14, O, T, and Z-Spill ....

Figure 28. Boxplots of oxidation-reduction potential in sediment samples collected on seven sampling dates from agricultural drains: Trifolium 20, Poe, Trifolium 18, Trifolium 14, O, T, and Z-Spill .....

Figure 29. Boxplots of Schoklitsch $\mathbf{s}$ (also referred to as "sediment particle size index") in sediment samples collected on seven sampling dates from agricultural drains: Trifolium 20, Poe, Trifolium 18, Trifolium 14, O, T, and Z-Spill.....

Figure 30. Boxplots of total organic carbon content in sediment samples collected on seven sampling dates from agricultural drains: Trifolium 20, Poe, Trifolium 18, Trifolium 14, O, T, and Z-Spill ..... 52

Figure 31. Boxplots of total selenium concentration in sediment samples collected on seven sampling dates from agricultural drains: Trifolium 20, Poe, Trifolium 18, Trifolium 14, 0, T, and Z-Spill.

Figure 32. Graph of selenium concentrations in sediment samples and unfiltered water samples from 29 drains and ponds during April 2006-09, and from seven drains during October 2006-08.

Figure 33. Graph of abundance (as catch-per-unit-effort) of western mosquitofish (GMB), sailfin molly (SLM), redbelly tilapia (RT), hybrid Mozambique tilapia (MT), red shiner (RSH), desert pupfish (DP), bluegill (BG), common carp (CP), and goldfish (GF) in 29 agricultural drains and ponds

Figure 34. Graph of abundance (as catch-per-unit-effort) of western mosquitofish (GMB), sailfin molly (SLM), redbelly tilapia (RT), hybrid Mozambique tilapia (MT), red shiner (RSH), desert pupfish (DP), bluegill (BG), common carp (CP), and goldfish (GF) on 15 sampling dates.

Figure 35. Graph of sampling dates and selenium concentrations in filtered water from seven agricultural drains

Figure 36. Graph of sampling dates and selenium concentrations in sediment from seven agricultural drains ...... 58 Figure 37. Graph of sampling dates and selenium concentrations in particulate organic detritus from seven agricultural drains

Figure 38. Graph of sampling dates and selenium concentrations in filamentous algae from seven agricultural drains

Figure 39. Graph of sampling dates and selenium concentrations in net plankton from seven agricultural drains

Figure 40. Graph of sampling dates and selenium concentrations in midge larvae from seven agricultural drains 


\section{Figures-Continued}

Figure 41. Graph of sampling dates and selenium concentrations in western mosquitofish from seven agricultural drains

Figure 42. Graph of sampling dates and selenium concentrations in sailfin molly from seven agricultural drains

Figure 43. Graph of particulate and dissolved selenium fractions in unfiltered water samples from seven intensively monitored agricultural drains. Dissolved fractions consisted of selenate, selenite, and organic selenium

Figure 44. Graph of particulate and dissolved selenium fractions in unfiltered water samples collected on six sampling dates

Figure 45. Matrix of selenium concentrations $(\mu \mathrm{g} / \mathrm{mL}$ or $\mu \mathrm{g} / \mathrm{g}$ dry weight; all values roughly equivalent to "parts per million") in filtered water (TWAT), sediment (SED), particulate organic detritus (DET), filamentous algae (ALG), net plankton (NPT), midge larvae (MID), western mosquitofish (GMB), and sailfin molly (SLM)

Figure 46. Graph of selenium concentrations measured in filtered water samples and in particulate organic detritus .

Figure 47. Graph of trophic transfer factors (TTF) for midge larvae and selenium concentrations in particulate organic detritus

Figure 48. Graph of trophic transfer factors (TTF) for western mosquitofish and selenium concentrations in particulate organic detritus.

Figure 49. Graph of trophic transfer factors (TTF) for western mosquitofish and selenium concentrations in midge larvae.

Figure 50. Graph of trophic transfer factors (TTF) for sailfin molly and selenium concentrations in particulate organic detritus.

Figure 51. Graph of trophic transfer factors (TTF) for sailfin molly and selenium concentrations in midge larvae

\section{Tables}

Table 1. List of 29 agricultural drains and ponds selected for study as part of the baseline selenium monitoring project.

Table 2. Pearson product-moment correlation coefficients and $P$ values for selected water quality variables measured at 29 agricultural drains and ponds on a quarterly basis from July 2005 through April 2009

Table 3. Pearson product-moment correlation coefficients and $P$ values for selected sediment-quality variables measured either annually (during April 2006-09) or semi-annually (during April and October 2006-08) from as many as 29 agricultural drains and ponds

Table 4. Cumulative numbers of nine fish species captured with baited minnow traps from 29 agricultural drains and ponds (values are not adjusted for variable fishing effort), and number of sampling trips

Table 5. Catch-per-unit-effort (mean numbers of fish per 10 minnow traps fished for 1 hour) for nine fish species captured at roughly quarterly intervals between July 2005 and April 2009.

Table 6. Spearman rank correlation coefficients and $P$ values between abundances (catch-per-unit-effort) of various fish species caught with minnow traps at 29 agricultural drains and ponds over a 4-year time period ....... 79 Table 7. Spearman rank correlation coefficients and $P$ values between abundance (catch-per-unit-effort) of fish species captured with minnow traps and selected habitat variables. 


\section{Tables-Continued}

Table 8. Summary of moisture and total selenium concentrations in water, sediment, aquatic food-chain organisms, and surrogate fish species from combined samples collected in seven intensively monitored drains on six sampling dates between April 2006 and October 2008

Table 9. Results of two-way analysis of variance, as F-values and significance levels, for selenium concentrations in water, sediment, selected food-chain matrices, and two surrogate fish species sampled from seven intensively monitored agricultural drains on six sampling dates between April 2006 and October 2008

Table 10. Temporal variations in total dissolved selenium concentration of filtered water samples collected on six sampling dates from seven intensively monitored drains

Table 11. Spatial variations in total dissolved selenium concentration of filtered water samples collected from seven intensively monitored drains on six sampling dates

Table 12. Temporal variations in total selenium concentration of sediment samples collected on six sampling dates from seven intensively monitored drains.

Table 13. Spatial variations in total selenium concentration of sediment samples collected from seven intensively monitored drains on six sampling dates.

Table 14. Temporal variations in total selenium concentration of particulate organic detritus samples collected on six sampling dates from seven intensively monitored drains

Table 15. Spatial variations in total selenium concentration of particulate organic detritus samples collected from seven intensively monitored drains on six sampling dates

Table 16. Temporal variations in total selenium concentration of filamentous algae samples collected on six sampling dates from seven intensively monitored drains

Table 17. Spatial variations in total selenium concentration of filamentous algae samples collected from seven intensively monitored drains on six sampling dates

Table 18. Temporal variations in total selenium concentration of net plankton samples collected on

six sampling dates from seven intensively monitored drains

Table 19. Spatial variations in total selenium concentration of net plankton samples collected from seven intensively monitored drains on six sampling dates

Table 20. Temporal variations in total selenium concentration of midge larvae samples collected on six sampling dates from seven intensively monitored drains

Table 21. Spatial variations in total selenium concentration of midge larvae samples collected from seven intensively monitored drains on six sampling dates

Table 22. Temporal variations in total selenium concentration of western mosquitofish samples collected on six sampling dates from seven intensively monitored drains

Table 23. Spatial variations in total selenium concentration of western mosquitofish samples collected from seven intensively monitored drains on six sampling dates

Table 24. Temporal variations in total selenium concentration of sailfin molly samples collected on six sampling dates from seven intensively monitored drains

Table 25. Spatial variations in total selenium concentration of sailfin molly samples collected from seven intensively monitored drains on six sampling dates.

Table 26. Pearson product-moment correlation coefficients and $P$ values for total selenium concentrations measured in water, sediment, selected food-chain taxa, and surrogate fish species

Table 27. Pearson product-moment correlation coefficients and $P$ values for total selenium concentrations in sediments normalized for total organic carbon content ( $\mu \mathrm{g} \mathrm{Se} / \mathrm{g} \mathrm{TOC}$ ) and total selenium concentrations in filtered water ( $\mu \mathrm{g} \mathrm{Se} / \mathrm{L})$, selected food-chain taxa $(\mu \mathrm{g} \mathrm{Se} / \mathrm{g})$, and surrogate fish species $(\mu \mathrm{g} \mathrm{Se} / \mathrm{g})$..... 


\section{Conversion Factors}

\begin{tabular}{|c|c|c|}
\hline Multiply & By & To obtain \\
\hline \multicolumn{3}{|c|}{ Length } \\
\hline centimeter $(\mathrm{cm})$ & 0.3937 & inch (in.) \\
\hline millimeter (mm) & 0.03937 & inch (in.) \\
\hline meter $(\mathrm{m})$ & 3.281 & foot $(\mathrm{ft})$ \\
\hline kilometer (km) & 0.6214 & mile (mi) \\
\hline \multicolumn{3}{|c|}{ Area } \\
\hline square meter $\left(\mathrm{m}^{2}\right)$ & 0.0002471 & acre \\
\hline hectare (ha) & 2.471 & acre \\
\hline \multicolumn{3}{|c|}{ Volume } \\
\hline milliliter $(\mathrm{mL})$ & 0.03382 & ounce, fluid (fl. oz) \\
\hline liter $(\mathrm{L})$ & 33.82 & ounce, fluid (fl. oz) \\
\hline liter $(\mathrm{L})$ & 0.2642 & gallon (gal) \\
\hline cubic meter $\left(\mathrm{m}^{3}\right)$ & 264.2 & gallon (gal) \\
\hline cubic meter $\left(\mathrm{m}^{3}\right)$ & 0.0008107 & acre-foot (acre-ft) \\
\hline cubic hectometer $\left(\mathrm{hm}^{3}\right)$ & 810.7 & acre-foot (acre-ft) \\
\hline \multicolumn{3}{|c|}{ Mass } \\
\hline $\operatorname{gram}(\mathrm{g})$ & 0.03527 & ounce, avoirdupois (oz) \\
\hline kilogram (kg) & 2.205 & pound, avoirdupois (lb) \\
\hline
\end{tabular}

Temperature in degrees Celsius $\left({ }^{\circ} \mathrm{C}\right)$ may be converted to degrees Fahrenheit $\left({ }^{\circ} \mathrm{F}\right)$ as follows:

${ }^{\circ} \mathrm{F}=\left(1.8 x^{\circ} \mathrm{C}\right)+32$.

Specific conductance is given in millisiemens per centimeter at 25 degrees Celsius $\left(\mathrm{mS} / \mathrm{cm}\right.$ at $\left.25^{\circ} \mathrm{C}\right)$.

Concentrations of chemical constituents in water are given either in milligrams per liter (mg/L) or micrograms per liter $(\mu \mathrm{g} / \mathrm{L})$.

Concentrations of chemical constituents in biota are given either in milligrams per kilogram $(\mathrm{mg} / \mathrm{kg}$ ) or micrograms per gram $(\mu \mathrm{g} / \mathrm{g})$. 


\title{
Final Report: Baseline Selenium Monitoring of Agricultural Drains Operated by the Imperial Irrigation District in the Salton Sea Basin, California
}

\author{
By Michael K. Saiki, Barbara A. Martin, and Thomas W. May
}

\begin{abstract}
This report summarizes comprehensive findings from a 4-year-long field investigation to document baseline environmental conditions in 29 agricultural drains and ponds operated by the Imperial Irrigation District along the southern border of the Salton Sea. Routine water-quality collections and fish community assessments were conducted on as many as 16 sampling dates at roughly quarterly intervals from July 2005 to April 2009. The water-quality measurements included total suspended solids and total (particulate plus dissolved) selenium. With one exception, fish were surveyed with baited minnow traps at quarterly intervals during the same time period. However, in July 2007, fish surveys were not conducted because we lacked permission from the California Department of Fish and Game for incidental take of desert pupfish (Cyprinodon macularius), an endangered species. During April and October 2006-08, water samples also were collected from seven intensively monitored drains (which were selected from the 29 total drains) for measurement of particulate and dissolved selenium, including inorganic and organic fractions. In addition, sediment, aquatic food chain matrices [particulate organic detritus, filamentous algae, net plankton, and midge (chironomid) larvae], and two fish species (western mosquitofish, Gambusia affinis; and sailfin molly, Poecilia latipinna) were sampled from the seven drains for measurement of total selenium concentrations. The mosquitofish and mollies were intended to serve as surrogates for pupfish, which we were not permitted to sacrifice for selenium determinations. Water quality (temperature, dissolved oxygen, $\mathrm{pH}$, specific conductance, and turbidity) values were typical of surface waters in a hot, arid climate. A few drains exhibited brackish, near-anoxic conditions, especially during summer and fall when water temperatures occasionally exceeded 30 degrees Celsius. Total selenium concentrations in water were directly correlated with salinity and inversely correlated with total suspended-solids concentrations. Although pupfish were found in several drains, sometimes in relatively high numbers, the fish faunas of most drains and ponds were dominated by nonnative species, especially mosquitofish, mollies, and red shiner (Cyprinella lutrensis). Dissolved selenium in water samples from the seven intensively monitored drains ranged from 0.700 to 32.8 micrograms per liter $(\mu \mathrm{g} / \mathrm{L})$, with selenate as the major constituent. Selenium concentrations in other matrices varied widely among drains and ponds, with one drain (Trifolium 18) exhibiting especially high concentrations in food chain matrices [particulate organic detritus, 5.98-58.0
\end{abstract}


micrograms of selenium per gram ( $\mu \mathrm{g} \mathrm{Se} / \mathrm{g}) ;$ midge larvae, 12.7-50.6 $\mu \mathrm{g} \mathrm{Se} / \mathrm{g}]$ and in fish (mosquitofish, 13.2-20.2 $\mu \mathrm{g} \mathrm{Se} / \mathrm{g}$; sailfin mollies, 12.8-30.4 $\mu \mathrm{g} \mathrm{Se} / \mathrm{g}$; all concentrations are based on dry weights). Although selenium was accumulated by all trophic levels, biomagnification (defined as a progressive increase in selenium concentration from one trophic level to the next higher level) in midge larvae and fish occurred only at lower exposure concentrations. Judging mostly from circumstantial evidence, the health and wellbeing of poeciliids and pupfish are not believed to be threatened by ambient exposure to selenium in the drains and ponds.

\section{Introduction}

The Imperial Irrigation District (IID) operates and maintains many agricultural drains in the Imperial Valley of California, some of which discharge directly into the Salton Sea. Agricultural practices, such as water management and conservation, can affect the quality of drain water. Although the desert pupfish (Cyprinodon macularius), a federally listed endangered species, lives in many of these drains, its distribution and ecological status are poorly understood.

In October 2003, the IID entered into agreements with the Bureau of Reclamation, the State of California, and three local water agencies in southern California (henceforth referred to as "conservation partners") to reduce the amount of water taken from the Colorado River to 5,425.2 $\mathrm{hm}^{3}$ (4.4 million acre-ft), the State's normal-year entitlement. One of these agreements, the Quantification Settlement Agreement (http://www.crss.water.ca.gov/crqsa/index.cfm), contains a plan to transfer as much as $372.69 \mathrm{hm}^{3}$ (303,000 acre-ft) of conserved agricultural water from the IID service area to the southern California coast and Coachella Valley.

Resource managers are concerned that water conservation efforts will reduce the amount of wetland habitat associated with canals and drains in the IID service area. In addition, water quality in the wetland habitat could be adversely affected by increased concentrations of dissolved minerals, including trace elements, such as selenium. Although required in small amounts by many animals, abnormally high concentrations of selenium can be toxic to fish and wildlife (Lemly, 2002).

In July 2005, the U.S. Geological Survey (USGS) Western Fisheries Research Center (WFRC), in collaboration with the USGS Columbia Environmental Research Center (CERC), was contracted to conduct a multi-year baseline selenium monitoring project on as many as 32 agricultural drains operated by IID that support or potentially support desert pupfish. However, after a preliminary field reconnaissance visit to the 32 drains, a final list of 29 active drains (includes three pond-like habitats) was identified for monitoring.

The purpose of the selenium-monitoring project, which is divided into an extensive monitoring task (consists of sampling all 29 drains or ponds) and an intensive monitoring task (consists of sampling 7 of the 29 drains or ponds), is to characterize physical and chemical baseline conditions in representative agricultural drains operated by IID, with an emphasis on selenium concentrations in water, sediment, dietary components of desert pupfish, and tissues of two surrogate fish species. The seven intensively monitored drains were selected to include a broad range of selenium exposures (from low to high) as determined by total selenium concentrations measured in unfiltered water samples during three initial sampling events.

Specific objectives of the project were as follows: (1) document selenium concentrations in water, sediment, dietary components of desert pupfish, and tissues of surrogate fish species, such as western mosquitofish (Gambusia affinis) and sailfin molly (Poecilia latipinna); and (2) document other environmental variables, such as water quality, total suspended solids (TSS), and sediment particle size. In addition, although not specifically identified in the contract, we documented the incidental capture of any pupfish caught during supplemental monitoring of fish species in the drains. 
This comprehensive report covers findings from the 16 sampling events that occurred at roughly seasonal intervals from July 2005 to April 2009. As part of data interpretation, we compared our results on selenium concentrations in fish-forage organisms and surrogate fish species with preliminary findings from laboratory toxicological studies on desert pupfish conducted by CERC investigators with the intent to "...facilitate the informed application of management measures and actions to protect desert pupfish populations and habitat in IID drains." Collectively, the field and laboratory projects address a requirement of the draft 2002 FWS Biological Opinion (U.S. Fish and Wildlife Service, 2002), which directs the Bureau of Reclamation and its conservation partners to fund a study to determine the impacts of selenium on pupfish.

\section{Study Area and Methods}

The study area is located along the southern shore of the Salton Sea in Imperial County, California, about $140 \mathrm{~km}$ east of San Diego, $110 \mathrm{~km}$ west of Yuma, Arizona, and $45 \mathrm{~km}$ north of the U.S.-Mexico border (fig. 1). The 29 agricultural drains and ponds selected for study were as follows (arranged from west to east): Trifolium 23, San Felipe Wash, Trifolium 22, Former Trifolium 20, Trifolium 20, Trifolium 19, Poe, Trifolium 18, Trifolium Storm, Trifolium 1, Trifolium 14A, Trifolium 13, Trifolium 12, Lack \& Lindsey Pond, Vail 5 (McKendry) Pond, Pumice Pond, O, P, Q, R, S, T, U, W, Z-Spill, Niland 1, Niland 2, Niland 3, and Niland 4 (table 1). Although Lack \& Lindsey Pond, Vail 5 Pond, and Pumice Pond feature pool-like characteristics (that is, large open-water areas with little or no current flow), samples were collected at downstream reaches between the pooled water and the Salton Sea where opposite shorelines narrowed considerably to form channels that resembled other agricultural drains and where current flow was usually noticeable.

\section{Extensive Monitoring}

As part of extensive monitoring, samples were collected from 22 drains and ponds during April and October of each year (except October 2005 and April 2009, when all 29 drains were sampled) and from 29 drains and ponds during July and January of each year. Although the initial sampling event is listed as July 2005, most data collection for this time period was postponed until August because of a delay in finalizing the funding agreement between IID and USGS.

The drains and ponds were measured in-situ for routine water quality [temperature, dissolved oxygen, hydrogen-ion concentration $(\mathrm{pH})$, specific conductance, and turbidity], and unfiltered water samples were collected for analysis of TSS and total selenium. [Note: Only single unfiltered water samples were collected from each of the 29 drains and ponds during July 2005, October 2005, and January 2006. However, after a seemingly anomalous measurement of total selenium $(79.1 \mu \mathrm{g} / \mathrm{L})$ was observed in the sample from Trifolium 20 Drain during July 2005, duplicate samples were collected and analyzed on subsequent sampling dates (April 2006 to April 2009) to facilitate detection and resolution of potentially erroneous results.]

All measurements were made and samples were collected from fixed stations located below the lowermost tile drain outlet (see table 1 for geospatial coordinates of fixed stations). At each station, water samples were collected first, followed by in-situ measurements of routine water quality. Finally, water depth was measured. During April of each year, 5 sediment samples were collected from each of 
29 drains and ponds for field measurements of temperature, $\mathrm{pH}$, and oxidation-reduction potential (ORP), and a single composite of the 5 samples was then submitted for laboratory measurements of particle-size distribution, total organic carbon (TOC), and total selenium. In addition to these samples and measurements, other miscellaneous station and site conditions were recorded in the field, and a photograph of each station was taken. Although not part of the contracted work, we attempted to deploy as many as 10 baited minnow traps fished for 1 hour within each drain or pond to determine fish species composition and relative abundance.

\section{Intensive Monitoring}

In March 2006, the IID Implementation Team (IT) used preliminary results of total selenium measured in unfiltered water samples from the first three extensive sampling events (July and October 2005, and January 2006) to select seven drains (Trifolium 20, Poe, Trifolium 18, Trifolium 14, O, T, and Z-Spill; see fig. 1 for drain locations) for intensive monitoring. In addition, the IT determined that intensive monitoring would occur in April and October of each year, beginning in April 2006 and ending in October 2008. A final sampling event in April 2009 was designated for extensive sampling to complement the first three extensive sampling events in 2005-06.

From April 2006 to October 2008, the seven intensively monitored drains were visited on six sampling dates to collect water samples from fixed sampling stations (see table 1 for geospatial coordinates of the fixed stations). The water samples were filtered in the field, and the filtrate was saved for subsequent laboratory measurement of total dissolved selenium, dissolved selenite $\left(\left[\mathrm{SeO}_{3}\right]^{2-}\right)$, and dissolved selenite + selenate $\left(\left[\mathrm{SeO}_{3}\right]^{2-}+\left[\mathrm{SeO}_{4}\right]^{2-}\right)$. The filtrant (nonfilterable residue) also was saved for laboratory measurement of total particulate selenium. Dissolved selenate $\left(\left[\mathrm{SeO}_{4}\right]^{2-}\right)$ was computed by subtracting dissolved selenite from dissolved selenite + selenate. Dissolved organic selenium was computed by subtracting dissolved selenite + selenate from total dissolved selenium. Total selenium (also referred to as "total unfiltered selenium") was computed by summation of total dissolved selenium and total particulate selenium.

Sediment samples collected during intensive monitoring (October only, because samples collected in April were part of extensive monitoring) were analyzed in the laboratory for total selenium. The sampling design for collecting sediments in October was similar to that used during extensive monitoring.

Composite samples of potential forage for desert pupfish [that is, particulate organic detritus, filamentous algae, net plankton, and midge (Chironomidae) larvae; see Moyle (2002) for summary information on pupfish diets] were collected for laboratory analysis of total selenium. Additionally, whole-body composite samples of western mosquitofish and sailfin mollies, which served as surrogates for desert pupfish, were collected with minnow seines, dip nets, and unbaited minnow traps for laboratory analysis of total selenium. The minnow traps were not baited to avoid potential contamination by sodium selenite, which is an additive ingredient in some brands of fish-flavored cat food.

In addition to collecting samples for selenium determinations, the seven drains were subjected to other sample collections and measurements typically made during extensive monitoring (for example, in-place measurements of routine water quality; collection of unfiltered water samples for analysis of TSS; collection of sediment samples for field measurements of temperature, $\mathrm{pH}$, and ORP, and laboratory measurement of particle-size distribution and TOC; and surveys of fish species). 


\section{Water-Quality Measurements}

Routine measurements of water quality variables (temperature, dissolved oxygen, $\mathrm{pH}$, specific conductance, and turbidity) were made in-situ at 5-minute intervals with a Hydrolab Datasonde 4 multiprobe logger (Hach Environmental, Loveland, Colorado) over a roughly 1-hour time period at each of the 29 drains and ponds. The measurements were taken about $15 \mathrm{~cm}$ beneath the water surface at the fixed stations. Specific conductance $\left(\mathrm{mS} / \mathrm{cm}\right.$ at $\left.25^{\circ} \mathrm{C}\right)$ was converted to salinity (parts per thousand, or \%o) by using the following equation: Salinity $=5.995 \times 10^{-8} * \mathrm{EC} 4-2.312 \times 10^{-5} * \mathrm{EC}^{3}+3.4346 \times$ $10^{-3} * \mathrm{EC}^{2}+0.53532 * \mathrm{EC}-0.015494$, where EC represents the specific conductance value (Hydrolab Corporation, 1997).

\section{Fish Species Composition and Abundance}

Fish were sampled for species composition and abundance from each of 29 drains or ponds by using as many as 10 minnow traps deployed about $5 \mathrm{~m}$ apart over a roughly 45 -m-long reach that included the permanent station. (Note: This sampling effort was separate from fish collections made during intensive monitoring to collect western mosquitofish and sailfin molly for selenium determinations.) Minnow traps measuring $25.4 \mathrm{~cm} \times 25.4 \mathrm{~cm} \times 43.2 \mathrm{~cm}$ with $3.2-\mathrm{mm}$ mesh were baited with about $60 \mathrm{~g}$ of canned cat food (Special Kitty® "Tuna Dinner" Premium Cat Food) held in a small plastic container (that is, a 35-mm photographic film canister) drilled with evenly spaced holes. Fishing effort for minnow traps was standardized at 1 hour to quantify the relative abundance of fish.

Captured fish were placed into plastic buckets filled with site water. Desert pupfish were measured for standard length and total length, then released alive in the capture vicinity. Nonnative fishes were identified and counted, and most were released alive in the capture vicinity.

\section{Collection of Samples for Selenium and Other Determinations}

The field procedures used to collect and temporarily store various sample matrices are briefly described below. Analytical procedures used by CERC for measuring selenium, TSS, sediment particlesize distribution, and sediment TOC are reported under separate cover by May and others (2006a, 2006b, 2007a, 2007b, 2008, 2009a, 2009b, 2009c).

\section{Unfiltered Water}

Each water sample collected for determination of total selenium was poured through a pre-filter (1-mm polypropylene sieve) attached to a 1-L pre-cleaned borosilicate glass bottle. Following collection, the water sample was acidified to $\mathrm{pH}<2$ with $6 \mathrm{~N}$ hydrochloric acid (OmniTrace ${ }^{\circledR}$, EMD Chemicals Inc., Gibbstown, New Jersey), then kept cold ( about $4^{\circ} \mathrm{C}$ ) and in the dark during storage and transport to analytical facilities at CERC. Each water sample collected for TSS measurement also was poured through a pre-filter (1-mm polypropylene sieve) attached to a pre-cleaned wide-mouth 1-L Nalgene ${ }^{\circledR}$ polypropylene bottle. The water samples collected for TSS measurement were refrigerated (about $4^{\circ} \mathrm{C}$ ) during storage and chilled on blue ice while being transported to CERC.

\section{Filtered Water}

Water collected for selenium speciation was filtered by using a battery-powered peristaltic Geotech Geopump $^{\mathrm{TM}}$ Series 1 (Geotech Environmental Equipment, Inc., Denver, Colorado), which was equipped with a standard pump head and high-capacity $0.45-\mu \mathrm{m}$ Geotech dispos-a-filter ${ }^{\mathrm{TM}}$ capsule. All tubing coming into sample contact was acid-cleaned silicone; a new length was used at each site and for 
the blank. At each site, $1 \mathrm{~L}$ of deionized water was filtered through the filter capsule, followed by site water. The first $200 \mathrm{~mL}$ of eluant was discarded, then $1 \mathrm{~L}$ of eluant was collected in an acid-cleaned 1-L borosilicate glass bottle and acidified to $\mathrm{pH}<2$ with $6 \mathrm{~N}$ hydrochloric acid (OmniTrace $\mathbb{R}$, EMD Chemicals). The acidified sample was stored and transported to CERC as described in the previous section, "Unfiltered Water."

Waterborne Particulates

A polycarbonate Geotech 142-mm plate filter apparatus was used with a 142-mm 0.4- $\mu \mathrm{m}$ polycarbonate filter to collect waterborne particulate matter for selenium determinations. At each site, $0.5 \mathrm{~L}$ of deionized water was filtered through the plate filter, followed by as much as $1 \mathrm{~L}$ of site water. After recording its volume, the filtered water was discarded. Each filter was placed in a pre-cleaned plastic petri dish $(150 \times 15 \mathrm{~mm})$ with particulate side up and sealed with its corresponding cover for freezer storage and eventual transport to CERC. After sampling was completed at each site, the plate filtration unit was rinsed with 0.1 percent nitric acid, followed by thorough rinsing with deionized water.

\section{Sediment}

Sediment samples were collected from all 29 drains and ponds in April, and from the 7 intensively monitored drains in October for measurement of temperature, $\mathrm{pH}$, ORP, particle-size distribution, TOC, and total selenium. Sediment was collected from a depth of 2-6 cm with a stainless steel dredge at five collection points along each drain. After collecting a sample, the dredge was cleared of mud and rinsed with site water. Prior to collecting a sample from a new site, the dredge was rinsed with deionized water and with water from the new site. In-situ measurements of temperature, $\mathrm{pH}$, and ORP were made by inserting glass electrodes directly into each sample prior to removal from the dredge. After combining equal volumes $(0.24 \mathrm{~L}$ each) of sediment from the five collection points to form a single, well-mixed composite sample, aliquots of the composite were placed into 0.47-L and 0.12 -L polypropylene containers (Nalgene ${ }^{\circledR}$ ). The $0.47-\mathrm{L}$ sample was used for analysis of particle-size distribution and TOC, whereas the 0.12-L sample was used for total selenium determination. (Note: The particle-size categories of sediment samples were roughly equivalent to the following pore diameters: clay, $<0.002 \mathrm{~mm}$; silt, 0.002-0.05 mm; sand, >0.05-2.0 mm; and gravel, $>2.0 \mathrm{~mm}$; see Foth and others, 1982.) Both sample containers were retained on blue ice until they were returned from the field and then refrigerated (about $4^{\circ} \mathrm{C}$ ) for storage and shipment to CERC.

\section{Filamentous Algae}

Filamentous algae was collected from floating mats and submerged sticks and rocks and temporarily held in a plastic Tupperware®-type container on blue ice. After returning from the field, the material was rinsed with deionized water, wrapped with plastic wrap, stored in a plastic Ziploc $®$ bag, and then frozen for storage and transport to CERC. 


\section{Net Plankton}

Plankton was collected by repeatedly casting and retrieving a student plankton net constructed of Nitex ${ }^{\circledR}$ bolting cloth, which has a mesh size of $80 \mu \mathrm{m}$ (Catalog No. 6JB-223527, Ben Meadows Company ${ }^{\circledR}$, Janesville, Wisconsin). After removing excess site water, each sample was rinsed three times with deionized water, then the plankton and any remaining rinse water were flushed into a $0.12-\mathrm{L}$ Nalgene ${ }^{\circledR}$ polypropylene container. The plankton samples were temporarily stored on blue ice, then immediately frozen upon return from the field. Subsequently, the frozen samples were transported to CERC for total selenium determinations.

\section{Midge Larvae and Particulate Organic Detritus}

Insect sweep nets were used to collect sediment and other bottom substrate materials containing a mix of benthic macroinvertebrates and particulate organic detritus; then site water and a polypropylene sieve were used to rinse away most extraneous mud and clay. Midge larvae and large pieces of organic detritus were hand-picked with plastic tweezers from the sieve and temporarily held in plastic Tupperware ${ }^{\circledR}$-type containers on blue ice. After returning from the field, the samples were rinsed with deionized water, wrapped in plastic wrap, then stored in plastic Ziploc ${ }^{\circledR}$ bags and frozen. The frozen samples were subsequently transported to CERC.

\section{Fish}

Fish were captured with unbaited minnow traps, dip nets, and a small seine, sorted according to species (western mosquitofish and sailfin mollies were retained), and temporarily held in plastic Tupperware ${ }^{\circledR}$-type containers on blue ice. After returning from the field, individuals of each species were measured for total length, weighed, and rinsed with deionized water. Composite samples, each consisting of as many as 20 fish of the same species, were wrapped in plastic wrap and placed into a plastic Ziploc ${ }^{\circledR}$ bag, then frozen. The frozen samples were subsequently transported to CERC.

\section{Quality Control for Selenium and Other Chemical Determinations}

The quality-control results for analytical determinations of samples collected during the 16 sampling events (July 2005 to April 2009) are reported by May and others (2006a, 2006b, 2007a, 2007b, 2008, 2009a, 2009b, 2009c). All results were within acceptable limits as specified by CERC.

\section{Data Management and Statistical Analysis}

Raw data were transcribed and stored as Microsoft ${ }^{\odot}$ Excel files on a desktop PC and summarized with SAS version 9.1 (SAS Institute Inc., Cary, North Carolina) or other statistical and graphical software. In general, statistical comparisons of water quality, sediment quality, and selenium concentrations were routinely subjected to logarithmic transformations when conducting analysis of variance (ANOVA) procedures, and geometric means were reported. However, TOC percentages were subjected to angular transformation (back-transformed angular means were reported), whereas $\mathrm{pH}$ values and ORP measurements were not subjected to any transformations (arithmetic means were reported). Arithmetic means were computed for sediment particle-size distribution (expressed as percentages) and used to estimate the Schoklitsch sediment factor, $\boldsymbol{s}$ (also referred to as "Schoklitsch $\boldsymbol{s}$ "), with a graphical technique described by Bogardi (1974); however, the Schoklitsch $\boldsymbol{s}$ was logarithmically transformed prior to conducting ANOVA procedures. Cluster analysis was done with geometric means of total selenium concentrations in unfiltered water samples to identify groups 
(clusters) of similar drains and ponds. Plots of the cubic clustering criterion (CCC; SAS Institute, Inc., 1989; p. 579), the pseudo $t^{2}$ statistic (PST2; SAS Institute Inc., 1989; p. 584), and the semipartial $\mathrm{r}^{2}$ statistic (SPRSQ; Khattree and Naik, 2000, p. 379) were used to identify an appropriate number of clusters. Pearson product-moment correlation was used to determine if pairs of variables exhibited significant associations. Although arithmetic means were used to summarize fish catch statistics (expressed as catch-per-unit-effort), statistical comparisons used nonparametric techniques (KruskalWallis test, Spearman rank correlation) because residuals were not normally distributed even after being subjected to standard transformations. Unless specified otherwise, the level of significance for rejecting null hypotheses of statistical tests was $P \leq 0.05$.

\section{Results and Discussion}

\section{Water Quality}

During this study, the 463 water-quality measurements from 29 agricultural drains and ponds collectively exhibited the following average characteristics: temperature, $19.09^{\circ} \mathrm{C}$ (range, $6.13-$ $35.91^{\circ} \mathrm{C}$ ); dissolved oxygen, $5.37 \mathrm{mg} / \mathrm{L}$ (range, 0.10-19.21 mg/L); $\mathrm{pH}, 7.84$ (range, 6.14-9.53); salinity, 1.81\%o (range, 0.57-39.20\%o); turbidity, 11.6 NTU (range, 0.0-970.0 NTU); TSS, 61.4 mg/L (range, $2.40-1,560 \mathrm{mg} / \mathrm{L}$ ); and total selenium in unfiltered samples, $4.18 \mu \mathrm{g} / \mathrm{L}$ (range, $0.790-79.1 \mu \mathrm{g} / \mathrm{L}$ ). In addition, water depth at fixed sampling sites averaged $26 \mathrm{~cm}$ (range, $0-93 \mathrm{~cm}$ ).

Except for temperature, all water-quality variables exhibited significant spatial variations over the 29 drains and ponds (temperature, $\mathrm{F}_{28,434}=0.77, P=0.8003$; dissolved oxygen, $\mathrm{F}_{28,434}=3.05$, $P<0.0001 ; \mathrm{pH}, \mathrm{F}_{28,434}=14.66, P<0.0001$; salinity, $\mathrm{F}_{28,434}=15.34, P<0.0001$; turbidity, $\mathrm{F}_{28,434}=5.61$, $\mathrm{P}<0.0001$; TSS, $\mathrm{F}_{28,434}=11.97, P<0.0001$; total selenium, $\left.\mathrm{F}_{28,434}=22.11, P<0.0001\right)$. However, no consistent recognizable spatial patterns were observed (see figs. 2-8).

Although total selenium concentrations in unfiltered water samples from the 29 drains and ponds did not exhibit recognizable spatial patterns, average selenium concentrations were considerably higher in some drains than in other drains (fig. 8). To better characterize the spatial variations, we conducted a cluster analysis of mean selenium concentrations that illustrated how various water bodies were related (see fig. 9). The plot of CCC values yielded a local peak corresponding to six clusters, whereas the plot of PST2 statistics (which identifies peak values of the statistic and takes the number of clusters to be one greater than the level at which each large value occurs) yielded two or six clusters (fig. 10). The plot of SPRSQ values (which detects the appropriate number of clusters by identifying a relatively small initial change in SPRS values that subsequently leads to much larger values) suggested either 6 or 7 clusters (fig. 11). Although subjective, we concluded from the evidence that the 29 drains and ponds were represented most consistently by six clusters, which collectively accounted for 99 percent of the total variation in selenium concentrations. The first cluster consisted of a single ultra-high-selenium drain (Trifolium 18 Drain, $24.8 \mu \mathrm{g} \mathrm{Se} / \mathrm{L}$ ). The second and third clusters were collectively represented by three high-selenium drains (Poe Drain, $8.49 \mu \mathrm{g} \mathrm{Se} / \mathrm{L}$; Q Drain, $10.84 \mu \mathrm{g} \mathrm{Se} / \mathrm{L}$; and Trifolium Storm Drain, $11.4 \mu \mathrm{g} \mathrm{Se} / \mathrm{L})$. The fourth cluster included six drains with moderately elevated selenium concentrations (5.28-6.9 $\mu \mathrm{g} \mathrm{Se} / \mathrm{L})$, whereas the fifth cluster consisted of 10 drains exhibiting slightly elevated selenium concentrations (3.51-4.68 $\mu \mathrm{g} \mathrm{Se} / \mathrm{L})$. Finally, the sixth cluster was represented by nine drains exhibiting relatively low concentrations of selenium $(1.53-3.14 \mu \mathrm{g} \mathrm{Se} / \mathrm{L})$. 
Water-quality variables were examined for temporal variations by grouping together data from the 29 drains and ponds (figs. 12-18). Evidence of variation among sampling dates was found for temperature $\left(\mathrm{F}_{15,447}=111.12, P<0.0001\right)$, dissolved oxygen $\left(\mathrm{F}_{15,447}=13.68, P<0.0001\right), \mathrm{pH}\left(\mathrm{F}_{15,447}=3.12\right.$, $P<0.0001)$, salinity $\left(\mathrm{F}_{15,447}=2.07, P=0.0104\right)$, and turbidity $\left(\mathrm{F}_{15,447}=3.33, P<0.0001\right)$, but not for TSS $\left(\mathrm{F}_{15,447}=1.13, P=0.3247\right)$, and total selenium $\left(\mathrm{F}_{15,447}=0.91, P=0.5506\right)$. In general, temperature was highest in July, intermediate in April and October, and lowest in January (fig. 12). By comparison, dissolved oxygen concentration was highest in January, followed by April and October, and lowest in July (fig. 13). Although significant temporal variations were detected for $\mathrm{pH}$, salinity, and turbidity, no recognizable seasonal patterns were observed (figs. 14-16).

Judging from Pearson product-moment correlation coefficients, direct relations existed between dissolved oxygen and $\mathrm{pH}, \mathrm{pH}$ and TSS, salinity and total selenium, and turbidity and TSS (table 2). In addition, inverse relations existed between temperature and dissolved oxygen, dissolved oxygen and salinity, $\mathrm{pH}$ and total selenium, salinity and turbidity, salinity and TSS, and TSS and total selenium (table 2).

\section{Sediment Quality}

A total of 137 measurements of sediment quality in the 29 drains and ponds were made during April 2006, April 2007, April 2008, and April 2009, and in the seven drains during October 2006, October 2007, and October 2008. Overall, sediment temperature averaged $19.79^{\circ} \mathrm{C}$ (range, $12.77-$ $29.94^{\circ} \mathrm{C}$ ), $\mathrm{pH}$ averaged 7.13 (range, 6.31-7.69), ORP averaged -208.2 $\mathrm{mV}$ (range, -417.8-212.7 mV), Schoklitsch $s$ averaged 0.0396 [range, 0.0019-0.3509; according to Bogardi (1974), the value of Schoklitsch $\boldsymbol{s}$, which can assume any arbitrary positive value, increases as sediment material becomes coarser], TOC averaged 1.53 percent (range, 0.03 to 11.63 percent), and total selenium averaged 1.05 $\mu \mathrm{g} \mathrm{Se} / \mathrm{g}$ (range, 0.078 to $10.0 \mu \mathrm{g} \mathrm{Se} / \mathrm{g}$ ). Although considerable variation was encountered, a combination of mostly sand, silt, and clay typically characterized the sediment samples (fig. 19). Sediment samples used to determine selenium concentrations exhibited an average moisture content of 46.8 percent (range, 21.1 to 77.8 percent).

Statistical comparisons of data on sediment quality over space and time were constrained by an unbalanced sampling design wherein all 29 drains and ponds were sampled during April of 2006, 2007, 2008, and 2009, but only 7 drains were sampled during October of 2006, 2007, and 2008. In addition, for some variables (that is, sediment particle size, which was used to compute Schoklitsch $s$, TOC, and total selenium), only one measurement was made from each drain or pond on all sampling dates except April 2006. Thus, for spatial comparisons, we limited statistical analyses to samples collected from the 29 extensively monitored drains and ponds during April. However, for temporal comparisons, we limited statistical analyses to samples collected from the seven intensively monitored drains during April and October.

Except for TOC, all sediment-quality variables exhibited significant spatial variations over the 29 drains and ponds (temperature, $\mathrm{F}_{28,87}=2.31, P=0.0017 ; \mathrm{pH}, \mathrm{F}_{28,87}=2.74, P=0.0002 ; \mathrm{ORP}, \mathrm{F}_{28,87}=4.28$, $\mathrm{P}<0.0001$; Schoklitsch $s, \mathrm{~F}_{28,87}=6.62 P<0.0001$; and total selenium, $\mathrm{F}_{28,87}=15.32 P<0.0001$ [figs. 2024]). However, no recognizable spatial patterns were observed. Total organic carbon was exceptional because spatial variation was not significant $\left(\mathrm{F}_{28,87}=1.40, P=0.1220\right.$; fig. 25$)$.

With one exception, none of the sediment-quality variables exhibited significant temporal variations (figs. 26-31). Total organic carbon was exceptional $\left(\mathrm{F}_{6,42}=13.78, P<0.0001\right.$; fig. 30) because higher percentages of TOC seemingly occurred early in the study (April and October 2006), then remained relatively low for the remainder of this study (April 2007 to April 2009). 
Pearson product-moment correlations indicated direct relations between ORP and $\mathrm{pH}, \mathrm{pH}$ and Schoklitsch $\boldsymbol{s}$, and TOC and total selenium (table 3). By comparison, inverse relations existed between ORP and TOC, and ORP and total selenium (table 3). Previous studies in the Salton Sea Basin and elsewhere have implicated particle size of the bottom sediment as a major factor controlling adsorption of selenium, with higher concentrations of selenium typically occurring in fine-grained sediments (silt and clay) than in coarser grained sediments (Setmire and Schroeder, 1998; Schroeder and others, 2002). However, the correlation between Schoklitsch $\boldsymbol{s}$ and total selenium in sediments was not significant (table 3), possibly because other variables (for example, dissolved selenium concentrations in overlying water, sediment ORP measurements, and sediment TOC percentages) obscured any simple relationships. Vogl and Henry (2002) also did not detect strong correlations between the sand, silt, or clay content and concentrations of metals and metalloids (including selenium) in sediments from the Salton Sea. Although Schroeder and others (2002) reported that TOC is often positively correlated with grain-size of sediments, we did not detect a significant correlation between TOC and Schoklitsch $\boldsymbol{s}$ during our study (table 3).

\section{Relation between Selenium in Sediment and Waterborne Selenium}

A significant correlation existed between selenium concentrations in sediment samples and unfiltered water samples ( $\mathrm{r}=0.29, P=0.0007, \mathrm{~N}=137$; see fig. 32). However, selenium concentrations in unfiltered water samples account for only 8 percent of the variation in selenium concentrations in sediment samples, indicating poor predictive capability. The occurrence of numerous outlier values could be due to short-term fluctuations in waterborne selenium concentrations within some drains.

\section{Fish Species Composition and Abundance}

Fish were not collected from several drains on one or more dates due to impassable road conditions that prevented access to sampling sites and inadequate drainwater flows that curtailed use of minnow traps. Fish sampling was most affected at Trifolium Storm Drain (samples were not collected on seven dates), followed by Trifolium 12 Drain (three dates), then by Former Trifolium 20 Drain, Trifolium 1 Drain, Lack \& Lindsey Pond, R Drain, T Drain, U Drain, and W Drain (one date each). Moreover, excessive growth of ditchbank vegetation occasionally prevented deployment of all 10 minnow traps at some drains. In addition, fish were not sampled during July 2007 because we lacked permission from the California Department of Fish and Game for incidental take of desert pupfish.

Despite logistical obstacles, 44,040 fish representing 9 species were captured with baited minnow traps during this study (table 4). The most numerous species was western mosquitofish $(\mathrm{N}=28,940)$, followed by sailfin molly $(\mathrm{N}=9,271)$, red shiner (Cyprinella lutrensis, $\mathrm{N}=4,334)$, desert pupfish (N=816), hybrid Mozambique tilapia (Oreochromis mossambica x O. urolepis, $\mathrm{N}=506$ ), bluegill (Lepomis macrochirus, $\mathrm{N}=120$ ), redbelly tilapia (Tilapia zillii, $\mathrm{N}=29$ ), and common carp and goldfish (Cyprinus carpio and Carassius auratus; for each, $\mathrm{N}=12$ ). In addition, 4,885 riverine grass shrimp (Palaemonetes paludosus), 386 red swamp crayfish (Procambarus clarkii), and 2 tadpoles (possibly American bullfrog, Lithobates catesbeianus, formerly Rana catesbeiana) were recovered from minnow traps.

Western mosquitofish was the most ubiquitous fish species, occurring in all 29 drains or ponds, followed in descending order by sailfin molly ( 28 drains or ponds), red shiner ( 23 drains or ponds), desert pupfish (22 drains or ponds), hybrid Mozambique tilapia (18 drains or ponds), bluegill (11 drains 
or ponds), redbelly tilapia (10 drains or ponds), and lastly by common carp and goldfish (3 drains or ponds each). Supplemental sampling with a small minnow seine yielded several largemouth bass (Micropterus salmoides) from T Drain, and hybrid Mozambique tilapia, common carp, largemouth bass, unidentified bullheads (Ameiurus sp.), and catfish (presumably channel catfish, Ictalurus punctatus) from Z-Spill Drain.

Spatial and temporal variations in fish catch statistics were examined after adjusting for fishing effort (catch-per-unit-effort or CPUE, where 1 CPUE represents 1 fish/10 traps fished for 1 hour, or 1 fish/10-trap-hours; see table 5 and figs. 33-34). According to Kruskal-Wallis test results (used to analyze the non-normally distributed data), a statistically significant difference occurred among various

drains and ponds $\left(\chi^{2}=87.54, \mathrm{df}=28, P<0.0001\right)$ : most fish were caught at Trifolium 19 Drain (mean, 775 fish/10-trap-hours), followed in descending order by T Drain (mean, 352 fish/10-trap-hours), Trifolium 18 Drain (mean, 305 fish/10-trap-hours), Niland 1 Drain (mean, 237 fish/10-trap-hours), U Drain (mean, 193 fish/10-trap-hours), Poe Drain (mean, 147 fish/10-trap-hours), Trifolium 23 Drain (mean, 135 fish/10-trap-hours), Trifolium 20 Drain (mean, 121 fish/10-trap-hours), R Drain (mean, 115 fish/10trap-hours), and O Drain (mean, 111 fish/10-trap-hours). At the remaining 19 drains and ponds, catch statistics averaged $<100$ fish/10-trap-hours. Catch statistics also varied over dates $\left(\chi^{2}=125.79, \mathrm{df}=14\right.$, $P<0.0001$ ); most fish were caught during the month of July (range, 278 fish/10-trap-hours in 2008 to $321 \mathrm{fish} / 10$-trap-hours in 2006), followed by October (range, 57 fish/10-trap-hours in 2008 to 167 fish/10-trap-hours in 2006), then about equally by January and April (range, 5 fish/10-trap-hours in 2007 to 54 fish/10-trap-hours in 2008). Overall, western mosquitofish accounted for nearly two-thirds of the combined catch (64.8 percent), followed by sailfin molly (21.6 percent), red shiner (9.6 percent), desert pupfish (2.4 percent), and hybrid Mozambique tilapia (1.1 percent). The remaining four speciesbluegill, redbelly tilapia, common carp, and goldfish—collectively contributed about 0.5 percent to the combined catch.

\section{Relationships between Fish Species}

The abundances of six fish species exhibited one or more instances of significant positive correlations, with western mosquitofish showing the most between-species correlations (5 species), followed by sailfin molly and hybrid Mozambique tilapia (4 correlations), then by redbelly tilapia and desert pupfish (3 correlations each), and lastly by red shiner ( 1 correlation; see table 6$)$. Abundance of pupfish was positively correlated with abundances of mosquitofish, mollies, and Mozambique tilapia. However, cursory observations made during supplemental seining within a drain suggested that specific reaches occupied by pupfish and mollies often differed from those occupied by mosquitofish.

\section{Relationships with Habitat Variables}

Abundances of several fish species were significantly correlated with selected habitat variables measured during our study (table 7). Five species (western mosquitofish, sailfin molly, hybrid Mozambique tilapia, red shiner, and desert pupfish) were positively correlated with temperature. Three species (mosquitofish, molly, and Mozambique tilapia) were negatively correlated with dissolved oxygen. These patterns reflect the seasonal nature of fish abundance (most species were caught in high numbers during July presumably because of spawning and subsequent growth of young-of-year fish, whereas many fewer fish were caught in January because of cumulative mortality from predation and other ecological stresses). Abundances of mollies, Mozambique tilapia, and pupfish were negatively correlated with TSS, whereas mollies and pupfish were positively correlated with salinity. Finally, 
abundances of mollies and Mozambique tilapia were positively correlated with waterborne selenium, whereas bluegill abundance was negatively correlated with this element. In all instances, however, the water-quality characteristics (independent variables) explained 15 percent or less of the variation in fish catch statistics, indicating poor predictive capability. None of the fish species was significantly correlated with $\mathrm{pH}$, turbidity, and Schoklitsch $\boldsymbol{s}$.

\section{Selenium Concentrations in Water, Sediment, Aquatic Food Chain Matrices, and Surrogate Fish Species}

Samples of water, sediment, aquatic food chain matrices (particulate organic detritus, filamentous algae, net plankton, and midge larvae), and surrogate fish species (western mosquitofish and sailfin molly) were collected for selenium determinations during intensive monitoring of Trifolium 20, Poe, Trifolium 18, Trifolium 14, O, T, and Z-Spill drains on six sampling dates from April 2006 to October 2008 (table 8). Total selenium concentrations ranged from 0.700 to $32.8 \mu \mathrm{g} / \mathrm{L}$ in filtered water, 0.330 to $10.0 \mu \mathrm{g} / \mathrm{g}$ in sediment, 0.850 to $58.0 \mu \mathrm{g} / \mathrm{g}$ in particulate organic detritus, 0.750 to $8.26 \mu \mathrm{g} / \mathrm{g}$ in filamentous algae, 0.150 to $19.3 \mu \mathrm{g} / \mathrm{g}$ in net plankton, 1.39 to $50.6 \mu \mathrm{g} / \mathrm{g}$ in midge larvae, 3.66 to 20.2 $\mu \mathrm{g} / \mathrm{g}$ in western mosquitofish, and 3.09 to $30.4 \mu \mathrm{g} / \mathrm{g}$ in sailfin mollies (except for water, all selenium concentrations reported in various matrices are given as dry weights).

According to two-way ANOVA, selenium concentrations in all matrices-filtered water, sediment, organic detritus, filamentous algae, net plankton, midge larvae, western mosquitofish, and sailfin mollies - exhibited significant Drain*Date interactions (table 9). The interactions indicated that independent variables (drains and dates) exerted a complex influence on the dependent variable (selenium concentrations). Therefore, the relations among selenium concentrations in one or more of the seven drains differed during one or more of the six sampling dates. When depicted graphically, significant interaction in various matrices was characterized by crossing-over of plots of date and selenium for each level of drain (see figs. 35-42).

Water

Setmire and Schroeder (1998) reported that irrigation water conveyed to the Imperial Valley contains about $2 \mu \mathrm{g} \mathrm{Se} / \mathrm{L}$, which increases to $6-28 \mu \mathrm{g} \mathrm{Se} / \mathrm{L}$ (median, $8 \mu \mathrm{g} \mathrm{Se} / \mathrm{L}$ ) in agricultural drainwater primarily due to evapotranspiration by crops. However, as previously mentioned, total selenium concentrations in unfiltered water samples collected from 29 agricultural drains and ponds during our study ranged from 0.790 to $79.1 \mu \mathrm{g} / \mathrm{L}$ (geometric mean, $4.18 \mu \mathrm{g} / \mathrm{L}$ ), with most drains exhibiting relatively low selenium concentrations (see fig. 9 for results of cluster analysis).

Speciation of unfiltered water samples from seven intensively monitored drains yielded average percentages of selenium constituents as follows: dissolved selenate $\left(\mathrm{SeO}_{4}{ }^{2-}\right), 82$ percent; dissolved selenite $\left(\mathrm{SeO}_{3}{ }^{2-}\right), 9$ percent; dissolved organic selenium, 8 percent; and particulate selenium, 1 percent. With some variation, these percentages generally were observed in all intensively monitored drains and sampling dates during the study (figs. 43-44). Total dissolved selenium can be estimated from measurements of total selenium in unfiltered water samples by the equation $\mathrm{Y}=0.9986 \mathrm{X}-0.0623(\mathrm{~N}=$ $\left.91, \mathrm{R}^{2}=0.9999\right)$, where $X=$ total selenium $(\mu \mathrm{g} / \mathrm{L}$, measured in unfiltered water samples) and $Y=$ total dissolved selenium $(\mu \mathrm{g} / \mathrm{L})$.

Although total dissolved selenium exhibited a significant Drain*Date interaction $\left(\mathrm{F}_{30,49}=374.51\right.$, $\mathrm{P}<0.0001)$, tests for simple effects showed that mean concentrations varied significantly over Dates within Drains (table 10) and over Drains within Dates (table 11). On average, Trifolium 18 Drain exhibited the highest concentrations of dissolved selenium with concentrations approaching or exceeding $15 \mu \mathrm{g} \mathrm{Se} / \mathrm{L}$ on all sampling dates, and a maximum concentration of $31.5 \mu \mathrm{g} \mathrm{Se} / \mathrm{L}$ was 
measured in April 2006 (tables 10, 11; fig. 35). Dissolved selenium concentrations exceeded $15 \mu \mathrm{g} \mathrm{Se} / \mathrm{L}$ in only two other drains on one sampling date each: Poe Drain in October 2006, $21.4 \mu \mathrm{g} \mathrm{Se} / \mathrm{L}$; and Trifolium 14 Drain in October 2007, $18.8 \mu \mathrm{g}$ Se/L. However, except for these two seemingly unusual events, dissolved selenium concentrations in Poe Drain, Trifolium 14 Drain, and the four remaining drains (Trifolium 20 Drain, O Drain, T Drain, and Z-Spill Drain did not exceed $10.1 \mu \mathrm{g}$ Se/L, and many measurements did not exceed $5 \mu \mathrm{g}$ Se/L. Trifolium 18 Drain also was unusual because the concentrations of dissolved selenium generally were higher during April than during October of each year. None of the other drains exhibited obvious seasonal patterns in dissolved selenium concentrations.

\section{Sediment}

Selenium concentrations in sediments exhibited a significant Drain*Date interaction $\left(\mathrm{F}_{30,14}=118.37, P<0.0001\right.$; table 9$)$ that was mostly associated with temporal variations in five drains (Trifolium 20 Drain, Trifolium 14 Drain, O Drain, T Drain, and Z-Spill Drain; plots of selenium concentrations and sampling dates exhibited considerable cross-over among these drains) containing low to moderately high selenium concentrations (0.470-3.31 $\mu \mathrm{g} \mathrm{Se} / \mathrm{g}$; see fig. 36 and tables 12-13). By comparison, concentrations in Poe Drain (which exhibited very low selenium concentrations, 0.330 $0.620 \mu \mathrm{g} \mathrm{Se} / \mathrm{g}$ ) and Trifolium 18 Drain (which exhibited high selenium concentrations, 4.67-10.0 $\mu \mathrm{g}$ $\mathrm{Se} / \mathrm{g}$ ) did not exhibit evidence of crossing-over with other drains. Moreover, selenium concentrations in two drains (O Drain and Z-Spill Drain) seemingly decreased in a progressive fashion from April 2006 to October 2008, whereas one drain (Trifolium 18 Drain) exhibited a progressive increase in selenium concentrations over the same time interval.

\section{Food Chain Organisms}

Selenium concentrations in samples of particulate organic detritus, filamentous algae, net plankton, and midge larvae exhibited significant Drain*Date interactions (table 9). When examined for simple effects, selenium concentrations in all matrices except organic detritus in Z-Spill Drain and net plankton in O Drain varied significantly over dates within drains, whereas all matrices including organic detritus and net plankton varied significantly over drains within dates (for organic detritus, see tables 14-15; for algae, see tables 16-17; for net plankton, see tables 18-19; for midge larvae, see tables 20-21). [Note: In several instances where F values were statistically significant, the subsequent Tukey's studentized range tests failed to separate the mean values under comparison (see examples in tables 14, 15,18 , and 19). Such results indicated that two or more of the mean values were different, but the differences were too small to be detected with the given sample sizes.] Although selenium concentrations typically were highest in Trifolium 18 Drain and lower in the other six drains, this pattern was not consistent over all dates (occasionally, one or more of the other drains exhibited higher concentrations than did Trifolium 18 Drain; for example, during April 2008, selenium concentrations in algae from O Drain, Z-Spill Drain, and Trifolium 20 Drain exceeded those from Trifolium 18 Drain). Moreover, even when selenium concentrations were highest in Trifolium 18 Drain, the relative ranking of remaining drains varied considerably so that no particular drain was always ranked as second highest in selenium concentration, third highest in selenium concentration, and so on. 
Particulate organic detritus consisted mostly of decaying plant remains, especially leaves and twigs from ditchbank vegetation and aquatic emergents (for example, salt cedar, Tamarix spp.; and cattails, Typha spp.). Unweighted geometric grand means for selenium concentrations in organic detritus ranged from $2.12 \mu \mathrm{g} / \mathrm{g}$ (range of means, 1.18-3.61 $\mu \mathrm{g} / \mathrm{g}$ ) at T Drain to $17.0 \mu \mathrm{g} / \mathrm{g}$ (range of means, 8.63-39.8 $\mu \mathrm{g} / \mathrm{g}$ ) at Trifolium 18 Drain (tables 14-15). Although selenium concentrations at 6 of 7 drains varied significantly over dates (Z-Spill Drain was exceptional because temporal variation was not significant), only Trifolium 18 Drain exhibited concentrations in excess of $11 \mu \mathrm{g} \mathrm{Se} / \mathrm{g}$ (table 14; also see fig. 37).

Filamentous algae collected for selenium determinations included taxa belonging to Chlorophyta (tentatively identified as a mix of Bulbochaete, Coleochaete, Oedogonium, and Stigeoclonium) and Chrysophyta (tentatively identified as Vaucheria). Unweighted geometric grand means for selenium concentrations in algae ranged from $1.45 \mu \mathrm{g} / \mathrm{g}$ (range of means, 0.767-2.96 $\mu \mathrm{g} / \mathrm{g}$ ) at Poe Drain to 4.61 $\mu \mathrm{g} / \mathrm{g}$ (range of means, $0.860-8.05 \mu \mathrm{g} / \mathrm{g}$ ) at Trifolium 18 Drain (tables 16-17). Trifolium 18 Drain was unusual not only because it typically exhibited the highest selenium concentrations in algal samples, but also because one sampling event in April 2008 was characterized by the second lowest mean concentration measured at the seven intensively monitored drains $(0.860 \mu \mathrm{g} \mathrm{Se} / \mathrm{g}$, which exceeded only the concentration of $0.767 \mu \mathrm{g} \mathrm{Se} / \mathrm{g}$ measured at Poe Drain; see fig. 38). Although consistent temporal and spatial patterns were not observed, a possible temporal effect was noted at several drains ( for example, Trifolium 20 Drain, Poe Drain, Trifolium 18 Drain, Trifolium 14 Drain), where selenium concentrations seemingly were higher in October than in April of each year (table 16, fig. 38). However, this temporal pattern was not observed in algal samples from O Drain, T Drain, and Z-Spill Drain.

Net plankton included everything in the water column large enough to be retained by the Nitex ${ }^{\circledR}$ bolting cloth, such as copepods, cladocerans, water mites (Hydracarina), early instars of aquatic insects (especially corixids), aquatic and terrestrial plant fragments, and possibly phytoplankton or other algae. Unweighted geometric grand means for selenium concentrations in net plankton ranged from $1.09 \mu \mathrm{g}$ $\mathrm{Se} / \mathrm{g}$ (range of means, 0.168-3.49 $\mu \mathrm{g} / \mathrm{g}$ ) at Poe Drain to $6.01 \mu \mathrm{g} \mathrm{Se} / \mathrm{g}$ (range of means, 2.31-16.5 $\mu \mathrm{g} / \mathrm{g}$ ) at Trifolium 18 Drain (tables 18-19). Moreover, except for O Drain, significant temporal variations occurred in selenium concentrations at each intensively monitored drain, whereas significant spatial variations occurred over all sampling dates.

Although net plankton from Trifolium 18 Drain usually exhibited the highest concentrations of selenium, considerable variation occurred over sampling dates (fig. 39). For example, concentrations measured during April 2006 in samples from Trifolium 14 Drain (mean, $10.0 \mu \mathrm{g} \mathrm{Se} / \mathrm{g}$ ) exceeded those measured from Trifolium 18 Drain (mean, $4.67 \mu \mathrm{g} \mathrm{Se} / \mathrm{g}$ ). Similarly, concentrations measured during October 2008 in samples from three other drains (Z-Spill, mean, $2.68 \mu \mathrm{g} \mathrm{Se} / \mathrm{g}$; O Drain, mean, $2.75 \mu \mathrm{g}$ $\mathrm{Se} / \mathrm{g}$; and T Drain, mean, $3.08 \mu \mathrm{g} \mathrm{Se} / \mathrm{g}$ ) exceeded those measured from Trifolium 18 Drain (mean, 2.31 $\mu \mathrm{g} / \mathrm{g})$.

Selenium concentrations in midge larvae (which consisted mostly of Chironomus spp., with a few related genera, such as Pelopia and possibly Lasiodiamesa) exhibited significant temporal variations within each drain, and significant spatial variations within each sampling date (tables 20-21). Unweighted geometric grand means for selenium concentrations ranged from $3.47 \mu \mathrm{g}$ Se $/ \mathrm{g}$ (range of means, $2.50-4.25 \mu \mathrm{g} / \mathrm{g}$ ) at Z-Spill Drain to $24.8 \mu \mathrm{g} \mathrm{Se} / \mathrm{g}$ (range of means, $13.1-46.2 \mu \mathrm{g} / \mathrm{g}$ ) at Trifolium 18 Drain. Midge larvae from Trifolium 20 Drain exhibited a mean concentration of only $1.82 \mu \mathrm{g} \mathrm{Se} / \mathrm{g}$ in October 2007; however, much higher concentrations were recorded on other sampling dates. 
Unusually high selenium concentrations $(>40 \mu \mathrm{g} / \mathrm{g})$ were measured in midge larvae from Trifolium 18 Drain during April and October 2008 (table 20; fig. 40). At Poe Drain, selenium concentrations also increased during April and October 2008 (13.6 and16.8 $\mu \mathrm{g} / \mathrm{g}$, respectively), although the concentrations were much lower than at Trifolium 18 Drain.

\section{Surrogate Fish Species}

Selenium concentrations in western mosquitofish and sailfin mollies exhibited significant Drain*Date interactions (table 9). The significant interactions were mostly associated with temporal variations in selenium concentrations at Trifolium 20 Drain, Trifolium 14 Drain, O Drain, and T Drain (figs. 41-42).

Unweighted geometric grand means for selenium concentrations in western mosquitofish ranged from $5.27 \mu \mathrm{g} \mathrm{Se} / \mathrm{g}$ (range of means, 4.21-7.19 $\mu \mathrm{g} / \mathrm{g}$ ) at O Drain to $16.5 \mu \mathrm{g} \mathrm{Se} / \mathrm{g}$ (range of means, 14.1$18.7 \mu \mathrm{g} / \mathrm{g}$ ) at Trifolium 18 Drain (tables 22-23; also see fig. 41). The two lowest selenium concentrations $(<4.00 \mu \mathrm{g} / \mathrm{g})$ measured during this study occurred during October 2007 and April 2008 in mosquitofish from $T$ Drain, whereas the four highest concentrations $(>15.0 \mu \mathrm{g} / \mathrm{g})$ occurred during April 2006, April 2007, April 2008, and October 2008 in mosquitofish from Trifolium 18 Drain. On two sampling dates (April 2008 and October 2008), mosquitofish from Poe Drain also contained relatively high concentrations of selenium $(10.4$ and $14.9 \mu \mathrm{g} / \mathrm{g})$.

Unweighted geometric grand means for selenium concentrations in sailfin mollies ranged from $4.26 \mu \mathrm{g} \mathrm{Se} / \mathrm{g}$ (range of means, 3.61-5.36 $\mu \mathrm{g} / \mathrm{g}$ ) at O Drain to $19.7 \mu \mathrm{g} \mathrm{Se} / \mathrm{g}$ (range of means, 13.5-26.8 $\mu \mathrm{g} / \mathrm{g}$ ) at Trifolium 18 Drain (tables 24-25, fig. 42). During each of the six sampling dates, selenium concentrations were highest in mollies from Trifolium 18 Drain, followed by Poe Drain (fig. 42). During October 2006, mollies from Trifolium 20 Drain accumulated $>15 \mu \mathrm{g} \mathrm{Se} / \mathrm{g}$; however, selenium body burdens averaged less than one-half this concentration on other sampling dates. A possible seasonal pattern was observed in mollies from Trifolium 18 Drain, where fish seemingly exhibited higher selenium body burdens in October than in April of each year (fig. 42). However, a similar pattern was not discerned in mollies from other drains.

\section{General Patterns of Selenium Bioaccumulation}

In general, selenium concentrations were highest in sailfin mollies, western mosquitofish, midge larvae, and particulate organic detritus, followed by net plankton, filamentous algae, and sediment, and lowest in filtered water (fig. 45, table 8). Although considerable variation was present, selenium concentrations in filtered water, sediment, organic detritus, midge larvae, mosquitofish, and mollies were significantly correlated with each other (table 26). Selenium concentrations in algae and plankton were significantly correlated with each other and with sediment (plankton only), but not with filtered water, organic detritus, midge larvae, mosquitofish, or mollies (table 26). Collectively, these results are consistent with the hypothesis that selenium originates in agricultural drainwater and enters the aquatic food chain primarily by accumulating in organic detritus. Midge larvae accumulate selenium either directly from the drainwater or by consuming selenium-contaminated organic detritus. Similarly, mosquitofish and mollies accumulate selenium either directly from the drainwater or by consuming selenium-contaminated organic detritus, midges, and other potential forage. If algae and plankton are consumed by mosquitofish and mollies, these matrices do not seemingly serve as major sources of selenium bioaccumulation unless the mass of ingested material is much greater than that of other materials (detritus, midges, etc.). Significant correlations between selenium concentrations in sediment and several other matrices (for example, water, plankton, midges, mosquitofish, and mollies) may be artifacts caused by high proportions of organic detritus (or its homologue, TOC) occurring in sediment 
samples. When selenium concentrations in sediment were normalized for TOC (by dividing the dry weight sediment concentration by the percentage of TOC in sediment expressed as a decimal fraction; Wisconsin Department of Natural Resources, 2003), none of the correlations with selenium concentrations in water, detritus, algae, plankton, midges, mosquitofish, and mollies were significant (table 27).

The importance of particulate organic detritus as an initial receptor of selenium uptake in aquatic food chains exposed to seleniferous water, including agricultural drainwater, has been demonstrated by other investigators (for example, Zawislanski and others, 2001; Gao and others, 2003; Sundberg and others, 2006). In a study of the accumulation of metals in litter from five different plant species, Zawislanski and others (2001) observed as much as a 30 -fold increase in selenium concentrations in plant tissues initially placed in the litter bags. Zawislanski and others (2001) attributed the enrichment primarily to the association of very fine particle matter with detritus, either from the physical coating of detritus with organic and iron-rich microlayers or from coprecipitation with iron and manganese oxides. Gao and others (2003) reported that plant detritus (fallen litter) accumulated as much as $23.4 \mu \mathrm{g} \mathrm{Se} / \mathrm{g}$ (a factor of 1,286) when exposed to agricultural drainwater containing an average of $18.2 \mu \mathrm{g} \mathrm{Se} / \mathrm{L}$ in a flow-through experimental wetland system. According to Sundberg and others (2006), selenium in flue gas desulfurization wastewater flowing through a pilot constructed wetland treatment system became enriched in detritus as much as 26,300 times. Our results indicated that selenium was enriched considerably in organic detritus relative to ambient concentrations in filtered water (on average, selenium concentrations were roughly 975 times higher in detritus than in water; table 8), with the relationship best illustrated on logarithmic scales (fig. 46).

Contaminants associated with particulate organic detritus seemingly affect selenium exposure of benthic invertebrates, such as midge larvae in two primary ways. First, contaminants may be released from the sediment into pore water to which the midges are exposed, and uptake occurs from the porewater through permeable surfaces of the organism. Second, midges may accumulate contaminants by direct ingestion of detritus. On average, selenium concentrations in midges were approximately 1.2 times higher than in detritus (table 8), which indicates that midges tended to biomagnify this element. However, the relationship between selenium concentrations in midge larvae and their detrital food source (referred to as the trophic transfer factor, or TTF) varied inversely with the selenium concentration in detritus (fig. 47). Biomagnification of selenium occurred in midge larvae when organic detritus contained less than $9.67 \mu \mathrm{g} \mathrm{Se} / \mathrm{g}$. However, when the selenium concentration in organic detritus exceeded this value, the concentrations of this element that accumulated in midge larvae were somewhat less than corresponding concentrations measured in organic detritus, indicating that biomagnification had not occurred.

The lack of significant correlations between selenium concentrations in filamentous algae and midge larvae and between selenium concentrations in net plankton and midge larvae suggests that algae and plankton were not major sources of dietary selenium exposure in midges (table 26).

Western mosquitofish and sailfin mollies are known to consume both organic detritus and midge larvae, sometimes in considerable amounts (Moyle, 2002; Martin and Saiki, 2009). Significant correlations existed between selenium concentrations in organic detritus and mosquitofish, organic detritus and mollies, midge larvae and mosquitofish, and midge larvae and mollies (table 26). On average, selenium concentrations in fish were enriched about 1.2 times the concentrations measured in organic detritus, and about 1.1 times the concentrations measured in midge larvae, suggesting that fish tended to biomagnify the selenium occurring in their foods. However, inverse relations were observed in TTF values of mosquitofish and mollies collected over the ranges of selenium measured in organic detritus and midge larvae (figs. 48-51). Judging from best-fit power equations, selenium concentrations 
$<8.59 \mu \mathrm{g} / \mathrm{g}$ in organic detritus and $<7.16 \mu \mathrm{g} / \mathrm{g}$ in midge larvae resulted in biomagnification in mosquitofish, whereas selenium concentrations $<9.59 \mu \mathrm{g} / \mathrm{g}$ in organic detritus and $<6.79 \mu \mathrm{g} / \mathrm{g}$ in midge larvae resulted in biomagnification in mollies. At higher exposure concentrations of selenium, mosquitofish and mollies accumulated less than the concentrations present in organic detritus and midge larvae. An inverse relationship between TTF values and exposure concentrations was suggested by DeForest and others (2007), who hypothesized that organisms will actively accumulate essential elements, such as selenium, when present at low concentrations in their foods in order to meet metabolic needs, with regulation occurring through depuration processes when excessively high concentrations are present in foods. Conceptually, the key determinants of TTF values are the ingestion rate of the animal, the efficiency with which selenium is assimilated from food, and the rate constant describing selenium turnover or loss from the tissues of the animal (Luoma and Presser, 2009). The inverse relationship between TTF values and exposure concentrations could explain why some investigators have reported that selenium undergoes biomagnification (TTFs $>1.0$ ), whereas other investigators have reported no evidence of biomagnification (TTFs $\leq 1.0$ ).

The difference in selenium concentrations of particulate organic detritus and midge larvae at which this element is biomagnified by western mosquitofish and sailfin mollies suggests reduced bioavailability of this element in organic detritus relative to midge larvae. Although speculative, organic detritus might contain a higher proportion of poorly assimilated inorganic selenium (present on detrital surfaces as iron-rich microlayers, or from coprecipitation with iron and manganese oxides; Zawislanski and others, 2001), whereas midge larvae might contain a higher proportion of easily assimilated organic selenium (organic selenomethionine is more bioavailable than inorganic selenite or selenate; Besser and others, 1993). Additional study is needed to further examine this hypothesis.

Selenium concentrations in filamentous algae and net plankton were not significantly correlated with selenium concentrations in western mosquitofish and sailfin mollies (table 26). These results suggested that algae and plankton did not contribute substantially to selenium body burdens in the two fish species. Nevertheless, algae and plankton might indirectly influence selenium uptake in fish by contributing to the pool of particulate organic detritus.

\section{Relation of Measured Selenium Concentrations to Proposed Toxicity Thresholds}

Several investigators have proposed selenium toxicity thresholds for fish by attempting to link selenium concentrations in water, sediment, potential fish-forage organisms, and various tissue concentrations in fish to toxic endpoints, such as reductions in growth, survival, or reproductive success (for example, DeForest and others, 1999; Hamilton, 2002; Lemly, 2002; U.S. Environmental Protection Agency, 2004). Lemly (2002) recommended toxic effects thresholds, such as $2 \mu \mathrm{g} / \mathrm{L}$ of inorganic selenium in water, $2 \mu \mathrm{g} / \mathrm{g}$ in sediments, $3 \mu \mathrm{g} / \mathrm{g}$ in food-chain organisms, and $4 \mu \mathrm{g} / \mathrm{g}$ in whole fish. However, Lemly (2002) cautioned that his recommendations were intended to represent selenium concentrations at which toxic effects first begin to occur in sensitive fish species and not the point at which all species die from selenium poisoning. Although we are not aware of any recommended toxic thresholds for selenium-exposed poeciliids, such as western mosquitofish and sailfin mollies, limited evidence suggests a high tolerance for this taxonomic group. For example, Lemly (1993) reported that mosquitofish in Belews Lake, North Carolina, was 1 of only 3 species out of 20 to persist during selenium poisoning, although deformities were found on at least one sampling date. Field studies in seleniferous parts of California's San Joaquin Valley floor indicate that mosquitofish can accumulate whole-body concentrations as high as $430 \mu \mathrm{g}$ Se/g (Hothem and Ohlendorf, 1989), although stillbirths and deformed larvae were observed among the offspring (Saiki and Ogle, 1995). However, when selenium concentrations ranged from 3.96 to $17.5 \mu \mathrm{g} / \mathrm{g}$ in postpartum female mosquitofish and 5.35 to 
$29.2 \mu \mathrm{g} / \mathrm{g}$ in their newborn offspring, the offspring exhibited high ( $>96$ percent) survival and no evidence of teratogenesis (Saiki and others, 2004). Consequently, we suspect that mosquitofish and mollies from the present study, which accumulated 3.09-30.4 $\mu \mathrm{g} \mathrm{Se} / \mathrm{g}$ in whole-body composite samples, were probably not adversely affected by this element. The relatively high abundance of mosquitofish (94 fish/10-trap-hours) and mollies (198 fish/10-trap-hours) in Trifolium 18 Drain, the most seleniferous site sampled during our study, along with a lack of correlation between catch-perunit-effort of mosquitofish and dissolved selenium concentrations, and a positive correlation between catch-per-unit-effort of mollies and dissolved selenium concentrations, lend support to our contention that these two species did not experience adverse effects from exposure to ambient concentrations of selenium.

A major assumption of the present study was that the trophic ecology and the selenium status of western mosquitofish and sailfin mollies were similar to those of desert pupfish. Although a field study is underway to test this assumption, results are not yet available for interpretation. A laboratory study by other USGS researchers also is attempting to determine the toxic threshold of selenium for pupfish. However, preliminary data from the laboratory study have not yielded strong evidence of selenium toxicity in pupfish even at the maximum exposure levels of $52 \mathrm{mg} / \mathrm{kg}$ in diet and $53 \mu \mathrm{g} / \mathrm{L}$ in water (J.M. Besser, U.S. Geological Survey, CERC, Columbia, Missouri, written commun., 2009). Toxic endpoints from that laboratory study included survival and growth of juveniles and adults, egg production and hatching success, and larval survival, each measured at five selenium treatment levels. Although results are still pending on larval deformities and pathology, early evidence suggests these endpoints also will prove to be uninfluenced by selenium exposure. The only real area of uncertainty is with egg production, where varying degrees of reduction were observed among the selenium treatments. However, even there, the variations do not seemingly exhibit consistent statistical differences.

\section{Summary and Conclusions}

Our 4-year-long baseline selenium monitoring project attempted to document environmental conditions and selenium concentrations in agricultural drains operated by the Imperial Irrigation District (IID) along the southern border of the Salton Sea. The drains represented actual or potential habitats for desert pupfish. However, because of the endangered status of pupfish, western mosquitofish and sailfin molly were used as surrogate species when fish samples were sacrificed for selenium determinations.

Except for temperature, all water-quality variables measured during our study exhibited significant $(P<0.05)$ spatial variations, but we did not observe any consistent patterns. Evidence of temporal variation was found in temperature, dissolved oxygen, $\mathrm{pH}$, salinity, and turbidity, but not in total suspended solids (TSS) and total selenium. In general, temperature was highest in July, intermediate in April and October, and lowest in January. In contrast, dissolved oxygen was highest in January, intermediate in April and October, and lowest in July. Although temporal variations were detected in $\mathrm{pH}$, salinity, and turbidity, we did not recognize any patterns. A direct correlation was found between salinity and total selenium, whereas inverse correlations were found between $\mathrm{pH}$ and total selenium, and between TSS and total selenium.

Except for total organic carbon (TOC), all sediment-quality variables exhibited significant $(P<0.05)$ spatial variations although patterns were not observed. Moreover, except for TOC, none of the sediment-quality variables exhibited significant temporal variations. Higher percentages of TOC occurred early in the study (April and October 2006), then remained relatively low from April 2007 to April 2009. Pearson product-moment correlations indicated a direct relation between TOC and total selenium, and an inverse relation between oxidation-reduction potential (ORP) and total selenium. A significant correlation also existed between selenium concentrations in sediment samples and unfiltered 
water samples. However, selenium concentrations in unfiltered water samples accounted for only 8 percent of the variation in selenium concentrations in sediment samples, indicating poor predictive capability.

A total of 44,040 fish representing 9 species was captured with baited minnow traps during this study. After adjusting for fishing effort, a significant $(P<0.05)$ spatial difference was detected in fish abundance. Fish abundance also varied over time; most fish were caught during July, followed by October, then about equally by January and April. Abundance of desert pupfish was positively correlated with abundances of western mosquitofish, sailfin molly, and hybrid Mozambique tilapia, and with water temperature and salinity, and inversely correlated with TSS. However, the correlation between pupfish abundance and total selenium concentration in unfiltered water was not significant.

According to two-way Analysis of Variance (ANOVA), selenium concentrations in water, sediment, various food chain matrices (particulate organic detritus, filamentous algae, net plankton, midge larvae), and surrogate fish species (western mosquitofish and sailfin molly) exhibited significant $(P<0.05)$ Drain*Date interactions. The interactions indicated that relations among selenium concentrations in one or more agricultural drains differed during one or more of the sampling dates.

Selenium speciation of water samples yielded dissolved and particulate fractions of this element, with dissolved fractions contributing nearly 99 percent of the total selenium concentration.

Selenium concentrations generally were highest in sailfin molly, western mosquitofish, midge larvae, and particulate organic detritus, followed by net plankton, filamentous algae, and sediment, and lowest in filtered water. Although considerable variation was present, selenium concentrations in filtered water, sediment, organic detritus, midge larvae, mosquitofish, and mollies were significantly correlated with each other. However, selenium concentrations in algae and plankton were significantly correlated with each other and with sediment (plankton only), but not with filtered water, organic detritus, midge larvae, mosquitofish, and mollies. These results are consistent with the hypothesis that selenium originates in agricultural drainwater and enters the aquatic food chain primarily by accumulating in organic detritus. Midge larvae accumulate selenium either directly from the drainwater or by consuming selenium-contaminated organic detritus. Similarly, mosquitofish and mollies accumulate selenium either directly from the seleniferous drainwater or, more likely, by eating selenium-contaminated organic detritus, midges, and other foods. By comparison, algae and plankton probably are unimportant as major sources of selenium uptake by mosquitofish and mollies. Significant correlations between sediment and several other matrices (water, plankton, midges, mosquitofish, and molly) might be artifacts caused by high proportions of organic detritus (or its homologue, TOC) in the sediment samples.

Trophic transfer factors (TTF) computed for midge larvae (assumed to forage on particulate organic detritus) and for western mosquitofish and sailfin molly (assumed to forage on a combination of organic detritus and midge larvae) indicated that biomagnification (TTF $>1.0)$ occurred when selenium concentrations in forage were relatively low, but did not occur $(\mathrm{TTF} \leq 1.0)$ when selenium concentrations were greater than about $10 \mu \mathrm{g} / \mathrm{g}$. This dynamic relationship might help explain why selenium has been reported to biomagnify in some habitats but not in others.

Several investigators have proposed selenium toxicity thresholds for fish by attempting to link selenium concentrations in water, sediment, potential fish-forage organisms, and various tissue concentrations in fish to toxic endpoints, such as reductions in growth, survival, or reproductive success. Although we are not aware of toxic thresholds for selenium-exposed poeciliids, field evidence from elsewhere suggests a high tolerance for this taxonomic group. We suspect that western mosquitofish and sailfin mollies from the present study, which accumulated 3.09-30.4 $\mu \mathrm{g} \mathrm{Se} / \mathrm{g}$ (micrograms selenium per gram) in whole-body composite samples, probably were not adversely affected by this element. The 
relatively high average abundance of mosquitofish (94 fish/10-trap-hours) and mollies (198 fish/10-traphours) in Trifolium 18 Drain, the most seleniferous site sampled during our study, along with a lack of correlation between catch-per-unit-effort of mosquitofish and waterborne selenium concentrations, and a positive correlation between catch-per-unit-effort of mollies and waterborne selenium concentrations, lend support to our contention that these two species were not likely to have experienced adverse effects from ambient exposure to selenium. Preliminary results of a U.S. Geological Survey laboratory experiment with desert pupfish indicate that this species also is not expected to exhibit negative health effects from current levels of selenium exposure.

\section{Acknowledgments}

The authors are grateful to the Imperial Irrigation District (IID) and the USGS Fisheries: Aquatic and Endangered Resources Program for funding the work described in this report. Bruce Wilcox of IID assisted with contract management and provided invaluable logistical support. Jeff Tupen, Harry Ohlendorf, and other members of the IID Implementation Team provided project guidance and technical oversight. James Fairchild and Harry Ohlendorf reviewed an early draft of this report. USGS personnel who contributed significantly to this project in the field or laboratory included William Brumbaugh, Cory Emerson, Francine Mejia, Toni Russell, and Michael Walther.

\section{References Cited}

Besser, J.M, Canfield, T.J., and LaPoint, T.W., 1993, Bioaccumulation of organic and inorganic Se in a laboratory food chain: Environmental Toxicology and Chemistry, v. 12, p. 57-72.

Bogardi, J., 1974, Sediment Transport in Alluvial Streams: Budapest, Hungary, Akademiai Kiado, [Translated by Z. Szilvassy.]

DeForest, D.K., Brix, K.V., and Adams, W.J., 1999, Critical review of proposed residue-based selenium toxicity thresholds for freshwater fish: Human and Ecological Risk Assessment, v. 5, p. 1187-1228.

DeForest, D.K., Brix, K.V., and Adams, W.J., 2007, Assessing metal bioaccumulation in aquatic environments: the inverse relationship between bioaccumulation factors, trophic transfer factors and exposure concentration: Aquatic Toxicology, v. 84, p. 236-246.

Foth, H.D, Withee, L.V., Jacobs, H.S., and Thien, S.J., 1982, Laboratory Manual for Introductory Soil Science: Dubuque, Iowa, Wm. C. Brown Company, p. 21-22.

Gao, S., Tanji, K.K., Peters, D.W., Lin, Z., and Terry, N., 2003, Selenium removal from irrigation drainage water flowing through constructed wetland cells with special attention to accumulation in sediments: Water, Air, and Soil Pollution, v. 144, p. 263-284.

Hamilton, S.J., 2002, Rationale for a tissue-based selenium criterion for aquatic life: Aquatic Toxicology, v. 57, p. 85-100.

Hothem, R.L., and Ohlendorf, H.M., 1989, Contaminants in foods of aquatic birds at Kesterson Reservoir, California, 1985: Archives of Environmental Contamination and Toxicology, v. 18, p. 773786.

Hydrolab Corporation, 1997, DataSonde 4 and MiniSonde water quality multiprobes, User's Manual: Austin, Tex., 192 p.

Khattree, R., and Naik, D.N., 2000, Multivariate Data Reduction and Discrimination with SAS Software: Cary, N.C., SAS Institute Inc., 558 p.

Lemly, A.D., 1993, Guidelines for evaluating Se data from aquatic monitoring and assessment studies: Environmental Monitoring and Assessment, v. 28, p. 83-100. 
Lemly, A.D., 2002, Selenium Assessment in Aquatic Ecosystems; a Guide for Hazard Evaluation and Water Quality Criteria: New York, Springer-Verlag, 161 p.

Luoma, S.N., and Presser, T.S., 2009, Emerging opportunities in management of selenium contamination: Environmental Science \& Technology, v. 43, no. 22, p. 8483-8487.

Martin, B.A., and Saiki, M.K., 2009, Trophic relationships of small nonnative fishes in a natural creek and several agricultural drains flowing into the Salton Sea, and their potential effects on the endangered desert pupfish: Southwestern Naturalist, v. 54, p. 156-165.

May, T.W., Walther, M.J., and Brumbaugh, W.G., 2006a, Determination of total suspended solids and total selenium in water from the Salton Sea irrigation drains: year 1 extensive sampling: Columbia, MO, U.S. Geological Survey, Columbia Environmental Research Center, Final Report FY06-32-04, $26 \mathrm{p}$.

May, T.W., Walther, M.J., and Brumbaugh, W.G., 2006b, Determination of selenium in samples collected from Salton Sea irrigation drains in April and July of 2006: Columbia, MO, U.S. Geological Survey, Columbia Environmental Research Center, Final Report 8335 FY07-32-01, 55 p.

May, T.W., Walther, M.J., and Brumbaugh, W.G., 2007a, Selenium concentrations in irrigation drain inflows to the Salton Sea, California, October 2006 and January 2007: U.S. Geological Survey OpenFile Report 2007-1113, 18 p.

May, T.W., Walther, M.J., Saiki, M.K., and Brumbaugh, W.G., 2007b, Total selenium and selenium species in irrigation drain inflows to the Salton Sea, California, April and July 2007: U.S. Geological Survey Open-File Report 2007-1347, 18 p.

May, T.W., Walther, M.J., Saiki, M.K., and Brumbaugh, W.G., 2008, Total selenium and selenium species in irrigation drain inflows to the Salton Sea, California, October 2007 and January 2008: U.S. Geological Survey Open-File Report 2008-1178, 14 p.

May, T.W., Walther, M.J., Saiki, M.K., and Brumbaugh, W.G., 2009a, Total selenium and selenium species in irrigation drain inflows to the Salton Sea, California, October April and July 2008: U.S. Geological Survey Open-File Report 2009-1011, 17 p.

May, T.W., Walther, M.J., Saiki, M.K., and Brumbaugh, W.G., 2009b, Total selenium and selenium species in irrigation drain inflows to the Salton Sea, California, October 2008 and January 2009: U.S. Geological Survey Open-File Report 2009-1123, 14 p.

May, T.W., Walther, M.J., Saiki, M.K., and Brumbaugh, W.G., 2009c, Total selenium in irrigation drain inflows to the Salton Sea, California, April 2009: U.S. Geological Survey Open-File Report 2009$1230,10 \mathrm{p}$.

Moyle, P.B., 2002, Inland Fishes of California; revised and expanded: Berkeley, Calif., University of California Press, 502 p.

Saiki, M.K., Martin, B.A., and May, T.W., 2004, Reproductive status of western mosquitofish inhabiting selenium-contaminated waters in the Grassland Water District, Merced County, California: Archives of Environmental Contamination and Toxicology, v. 47, p. 363-369.

Saiki, M.K., and Ogle, R.S., 1995, Evidence of impaired reproduction by western mosquitofish inhabiting seleniferous agricultural drainwater: Transactions of the American Fisheries Society, v. 124, p. 624-635.

SAS Institute Inc., 1989, SAS/STAT user's guide, version 6 (4th ed.): Cary, N.C., SAS Institute Inc., v. $1,943 \mathrm{p}$.

Schroeder, R.A., Orem, W.H., and Kharaka, Y.K., 2002, Chemical evolution of the Salton Sea, California: nutrient and selenium dynamics: Hydrobiologia, v. 473, p. 23-45. 
Setmire, J.G., and Schroeder, R.A., 1998, Selenium and salinity concerns in the Salton Sea area of California, in Frankenberger, W.T., Jr., and Engberg, R.A., eds., Environmental Chemistry of Selenium: New York, Marcel Dekkar Inc., p. 205-221.

Sundberg, S.E., Hassan, S.M., and Rodgers, J.H., Jr., 2006, Enrichment of elements in detritus from a constructed wetland and consequent toxicity to Hyalella azteca: Ecotoxicology and Environmental Safety, v. 64, p. 264-272.

U.S. Environmental Protection Agency, 2004, Draft Aquatic Life Water Quality Criteria for Selenium 2004: Washington, DC, Office of Science and Technology, EPA-822-D-04-001.

U.S. Fish and Wildlife Service, 2002, Final biological opinion on the Bureau of Reclamation's voluntary fish and wildlife conservation measures and associated conservation agreements with the California water agencies: Memorandum FWS-IMP-2628. from Assistant Field Supervisor, Carlsbad Fish and Wildlife Office, U.S. Fish and Wildlife Service, Carlsbad, California, to Regional Director, Lower Colorado Region, U.S. Bureau of Reclamation, Boulder City, Nevada, 80 p.

Vogl, R.A., and Henry, R.N., 2002, Characteristics and contaminants of the Salton Sea sediments: Hydrobiologia, v. 473, p. 47-54.

Wisconsin Department of Natural Resources, 2003, Consensus-based sediment quality guidelines; recommendations for use and application interim guidance: Madison, WI, WT-732 2003, 35 p.

Zawislanski, P.T., Chau, S., Mountford, H., Wong, H.C., and Sears, T.C., 2001, Accumulation of selenium and trace metals on plant litter in a tidal marsh: Estuarine and Coastal Shelf Science, v. 52, p. 589-603. 


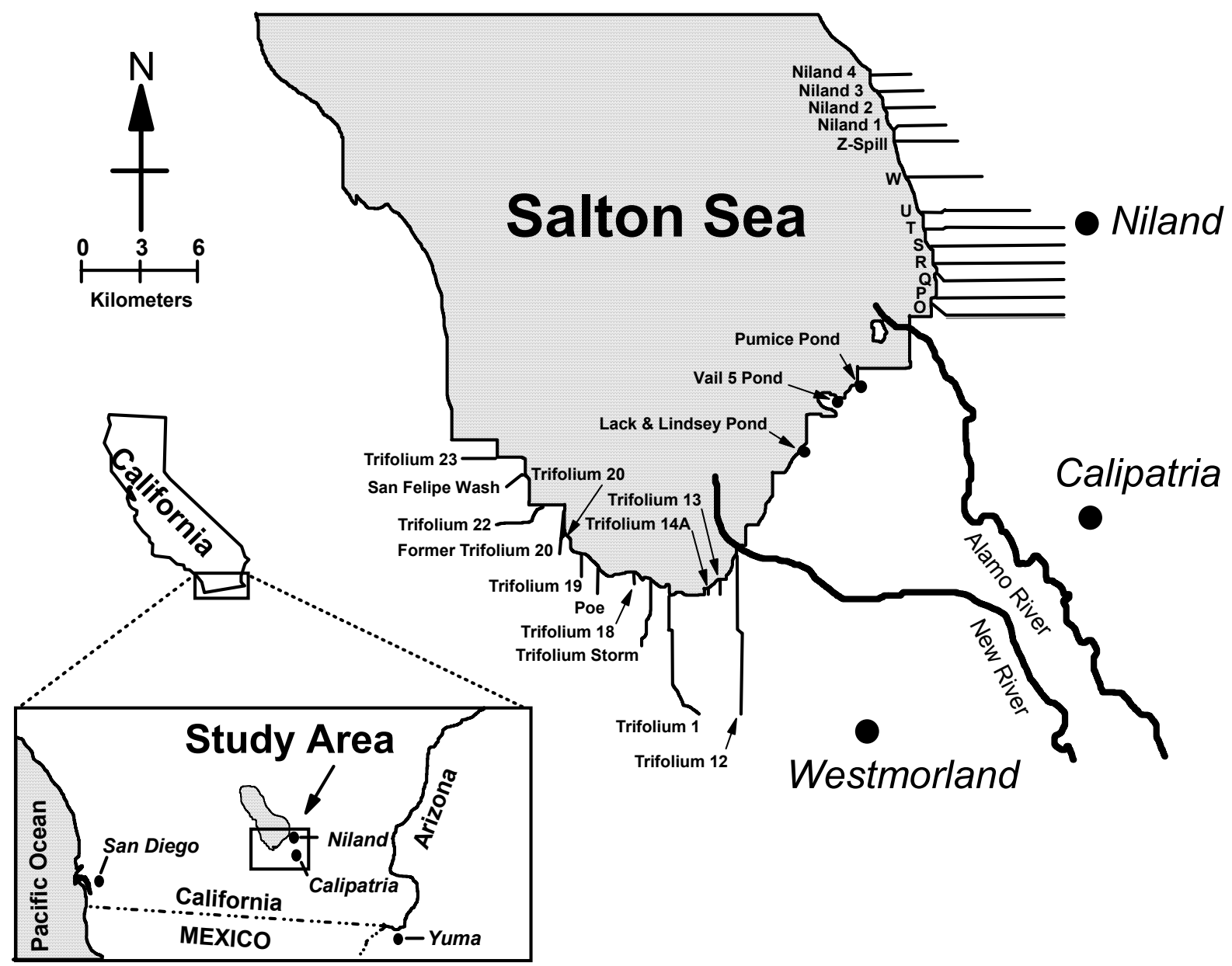

Figure 1. Map of the study area showing locations of 29 agricultural drains and ponds selected for extensive monitoring. 


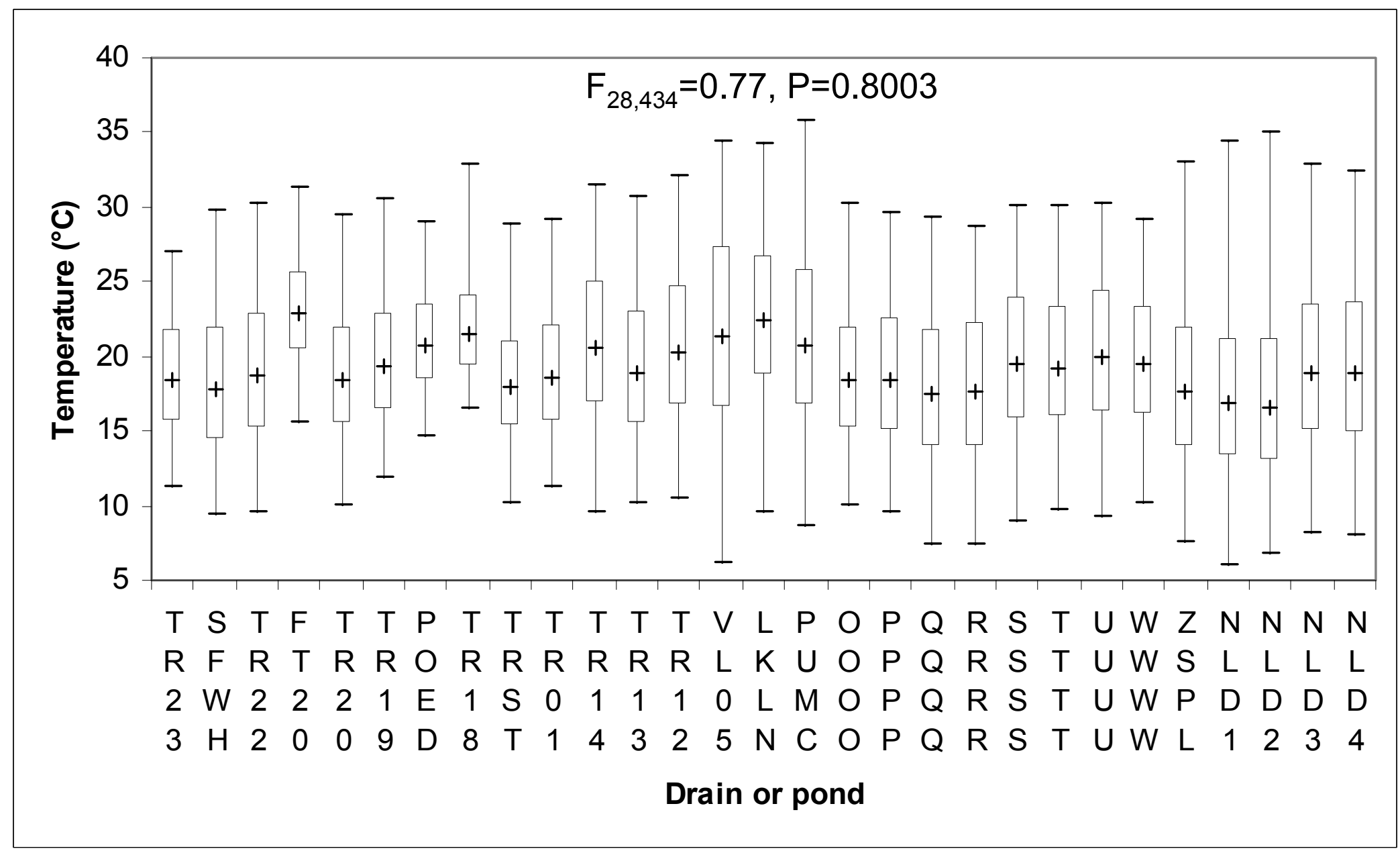

Figure 2. Boxplots of temperature in water from 29 agricultural drains or ponds measured on 16 sampling dates from July 2005 to April 2009. Symbols are geometric means (+), 95\% confidence intervals (box), and minimum and maximum values (vertical lines). Codes for drains and ponds are given in table 1. 


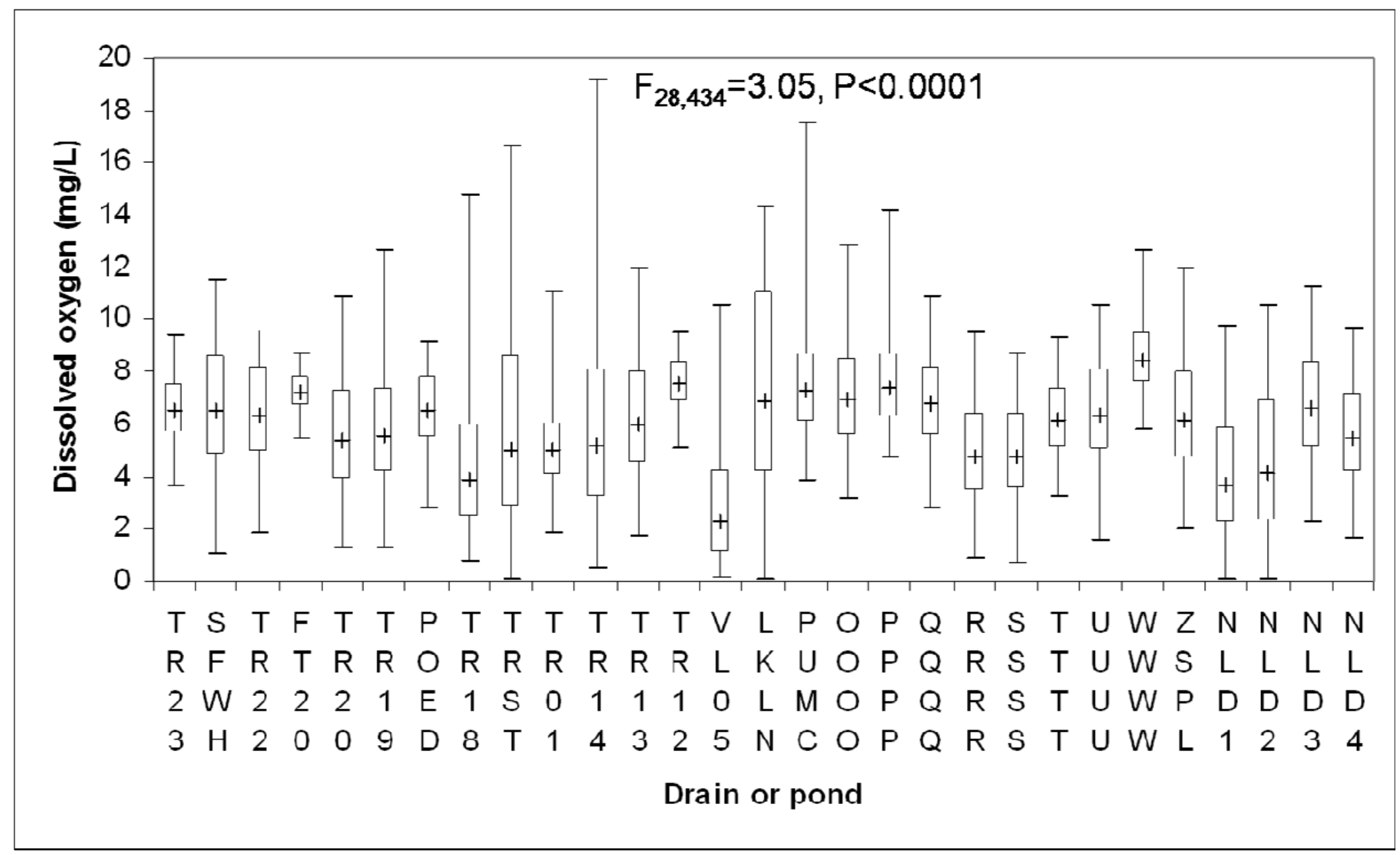

Figure 3. Boxplots of dissolved oxygen concentration in water from 29 agricultural drains or ponds measured on 16 sampling dates from July 2005 to April 2009. Symbols are geometric means (+), 95\% confidence intervals (box), and minimum and maximum values (vertical lines). Codes for drains and ponds are given in table 1. 


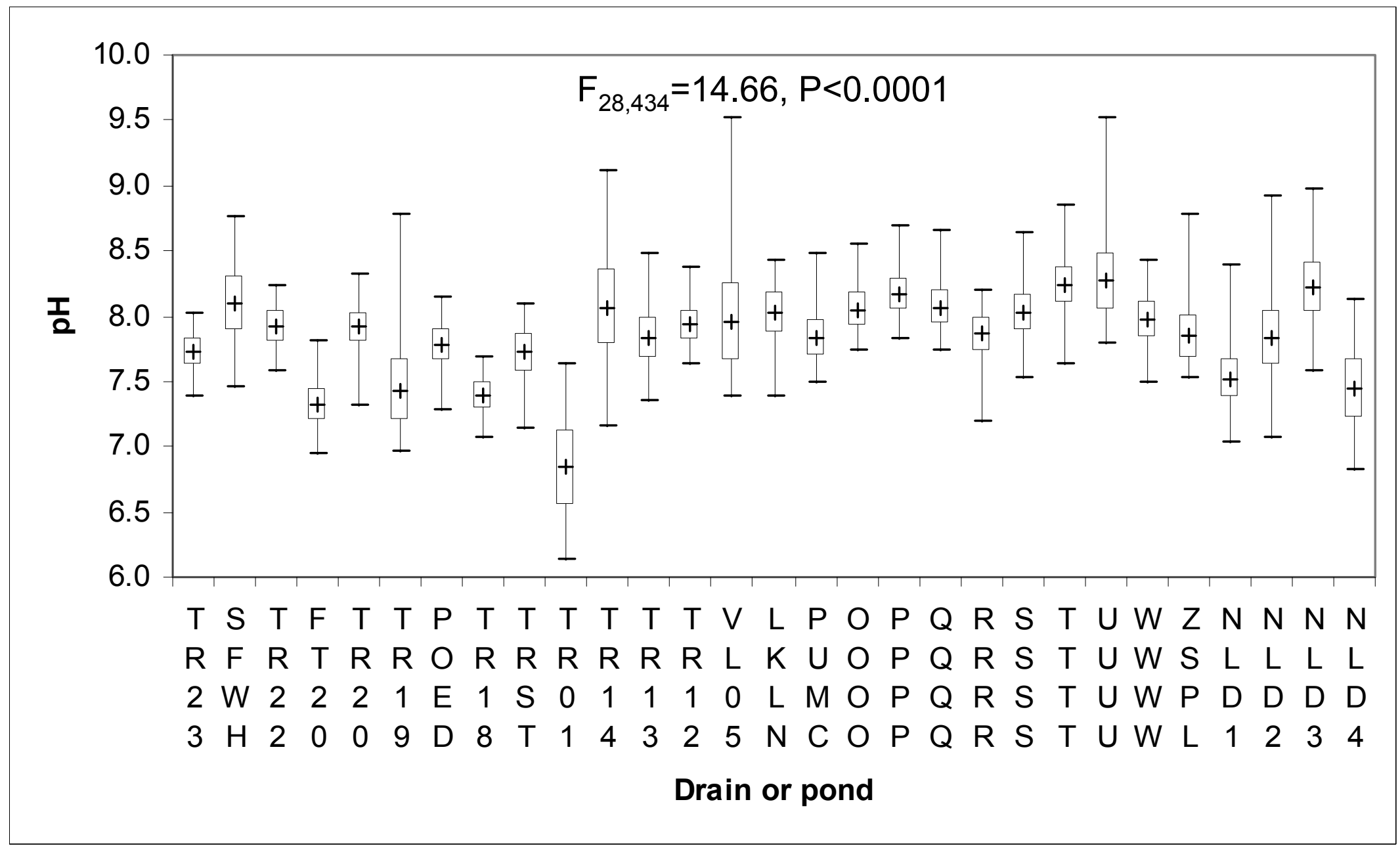

Figure 4. Boxplots of hydrogen-ion concentration $(\mathrm{pH})$ in water from 29 agricultural drains or ponds measured on 16 sampling dates from July 2005 to April 2009. Symbols are arithmetic means (+), 95\% confidence intervals (box), and minimum and maximum values (vertical lines). Codes for drains and ponds are given in table 1. 


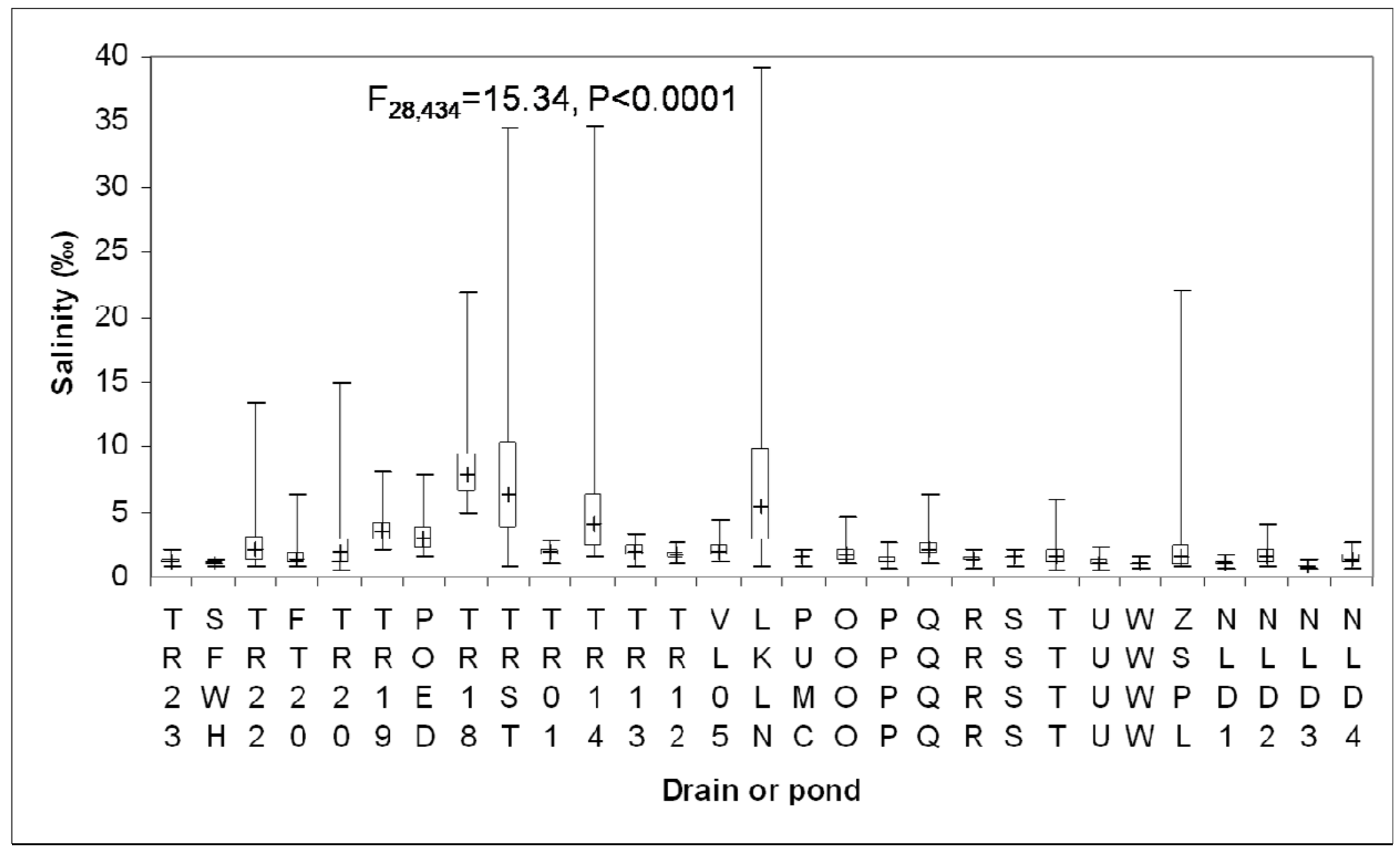

Figure 5. Boxplots of salinity concentration in water from 29 agricultural drains or ponds measured on 16 sampling dates from July 2005 to April 2009. Symbols are geometric means (+), 95\% confidence intervals (box), and minimum and maximum values (vertical lines). Codes for drains and ponds are given in table 1. 


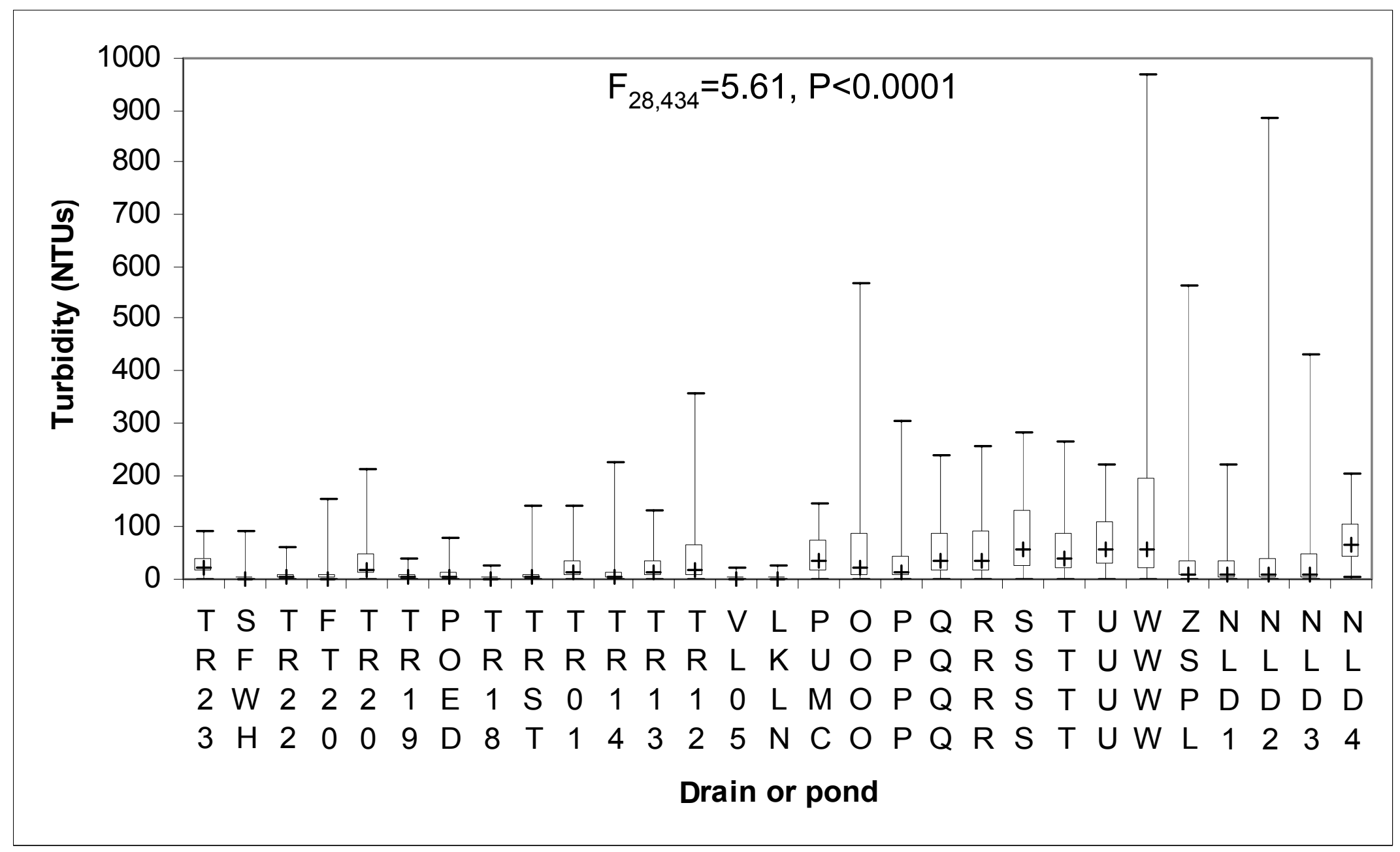

Figure 6. Boxplots of turbidity in water from 29 agricultural drains or ponds measured on 16 sampling dates from July 2005 to April 2009 . Symbols are geometric means (+), 95\% confidence intervals (box), and minimum and maximum values (vertical lines). Codes for drains and ponds are given in table 1. 


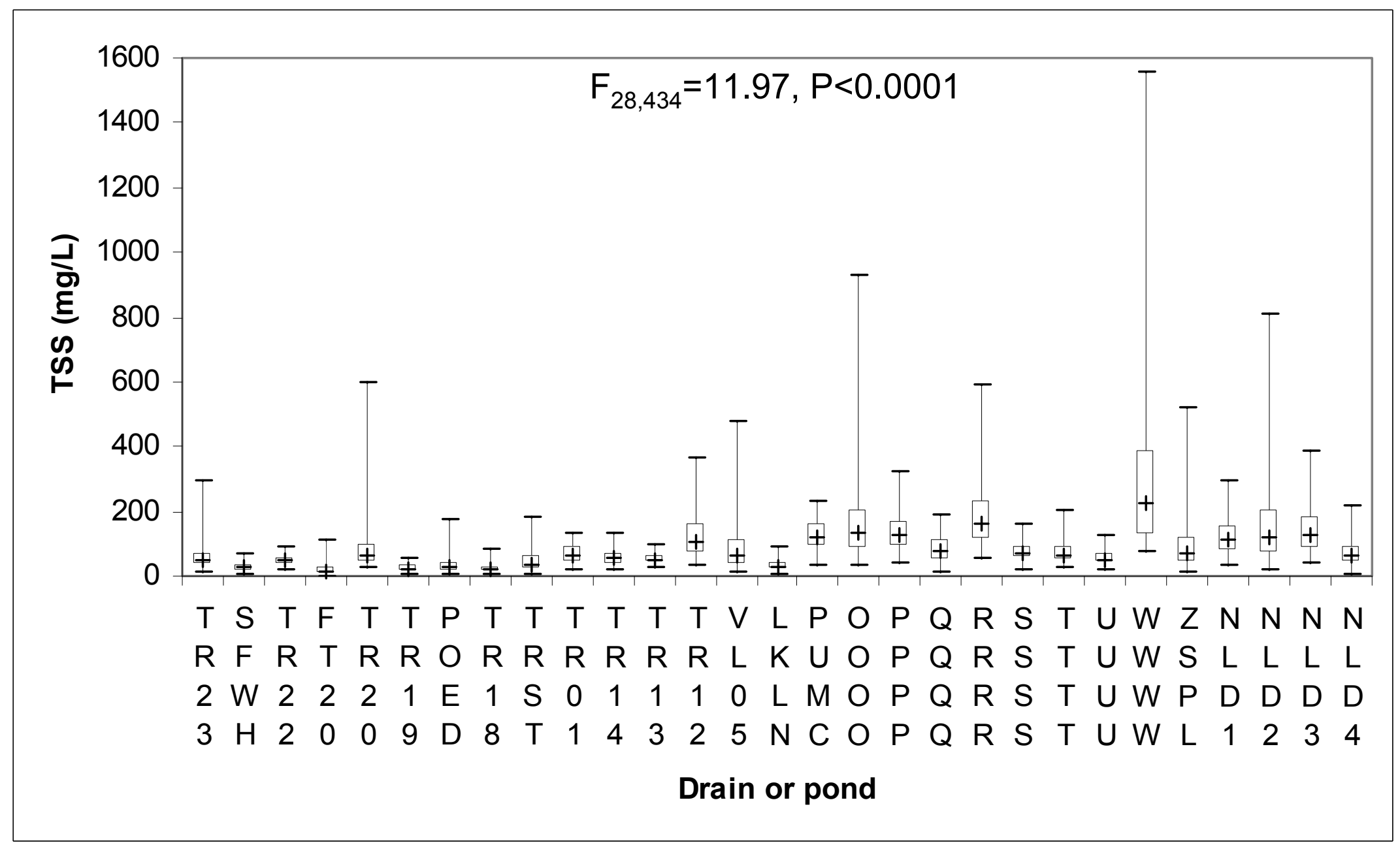

Figure 7. Boxplots of total suspended solids (TSS) concentration in water from 29 agricultural drains or ponds measured on 16 sampling dates from July 2005 to April 2009. Symbols are geometric means (+), 95\% confidence intervals (box), and minimum and maximum values (vertical lines). Codes for drains and ponds are given in table 1. 


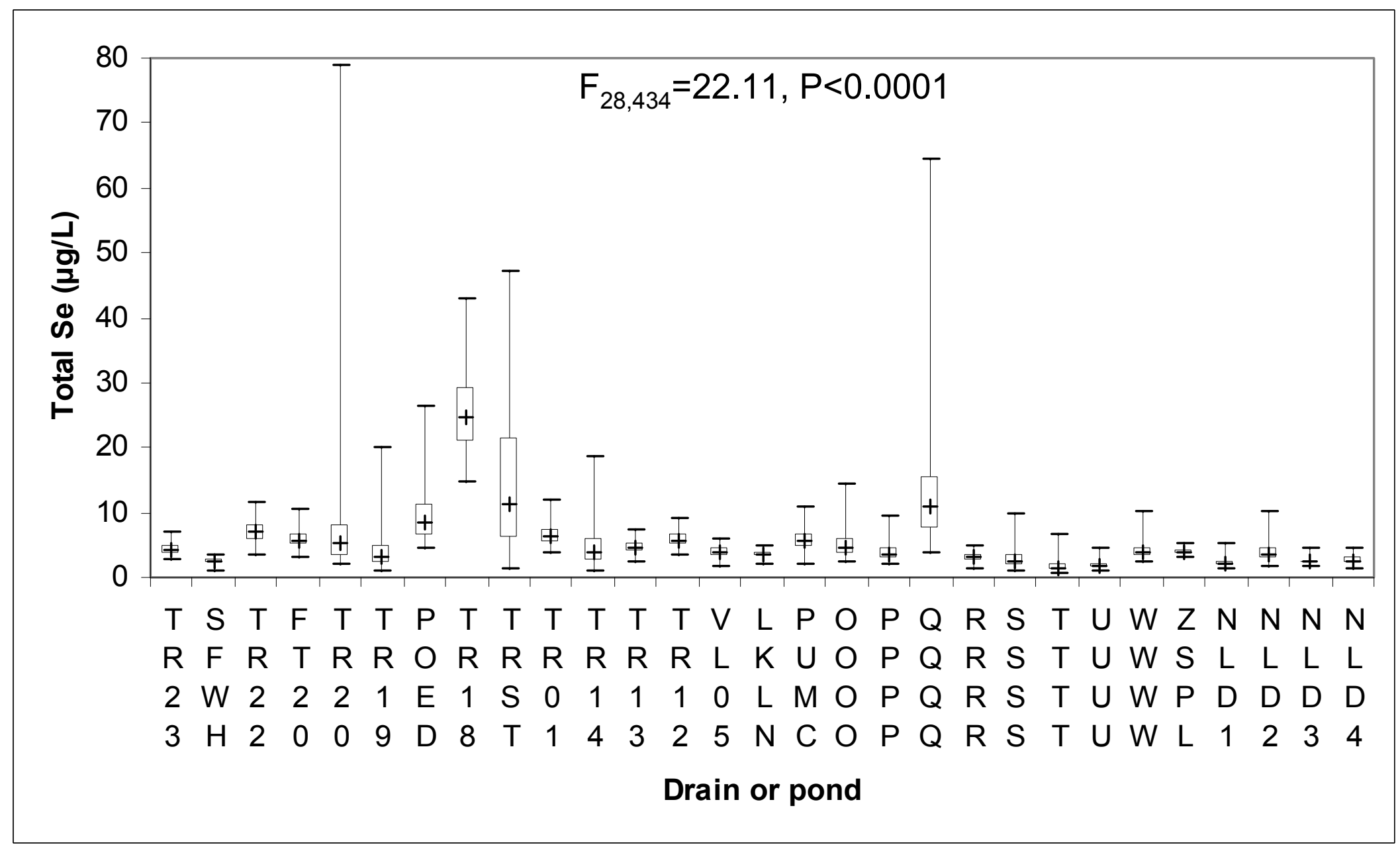

Figure 8. Boxplots of total selenium concentration in unfiltered water samples from 29 agricultural drains or ponds measured on 16 sampling dates from July 2005 to April 2009. Symbols are geometric means (+), 95\% confidence intervals (box), and minimum and maximum values (vertical lines). Codes for drains and ponds are given in table 1. 


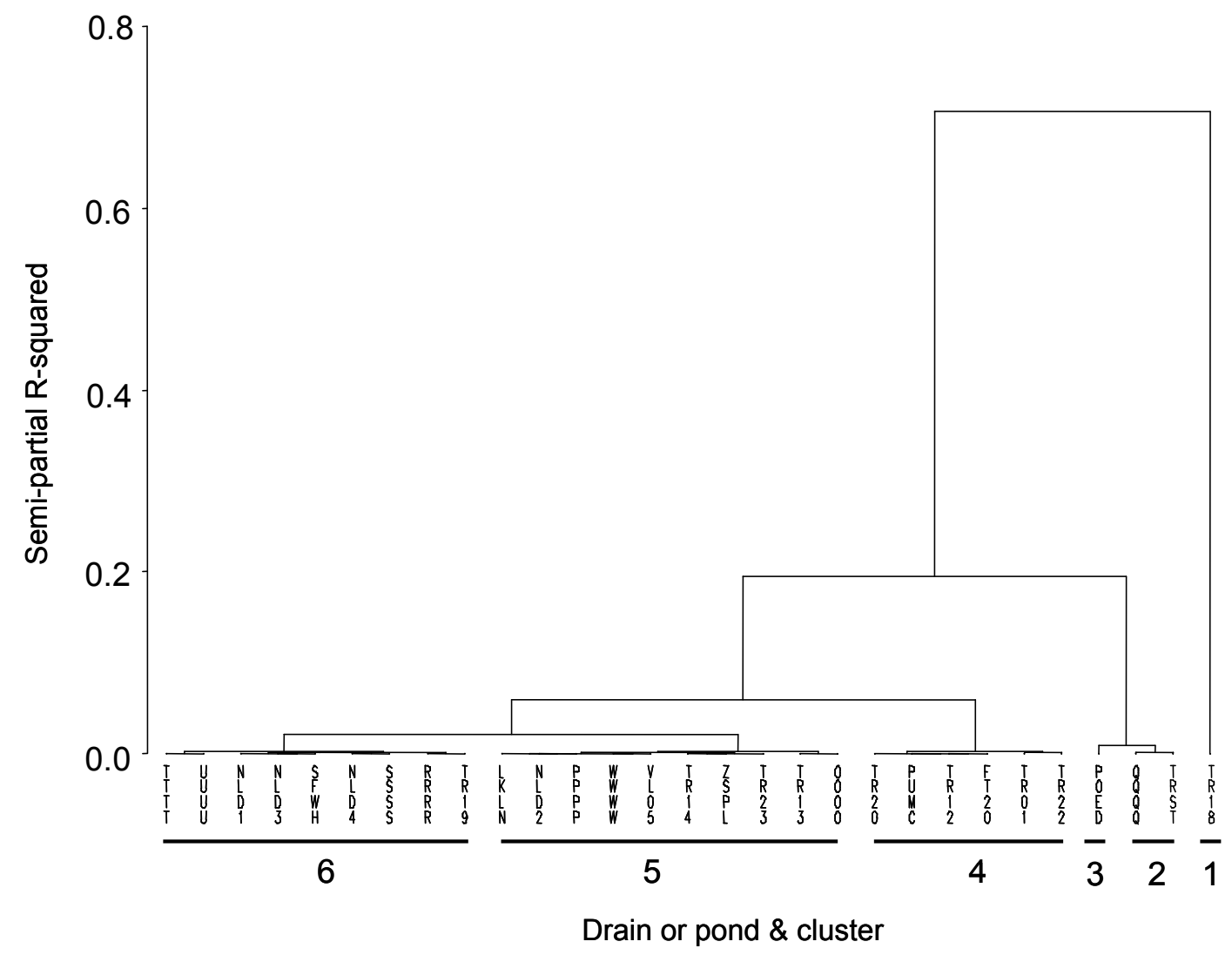

Figure 9. Dendrogram for cluster analysis (Ward's minimum-variance method) based on geometric mean values of total selenium concentrations in unfiltered water samples from 29 agricultural drains or ponds sampled on 16 sampling dates from July 2005 to April 2009. Selenium concentrations progressively increase from left to right among the drains and ponds. Codes for drains and ponds are given in table 1. 


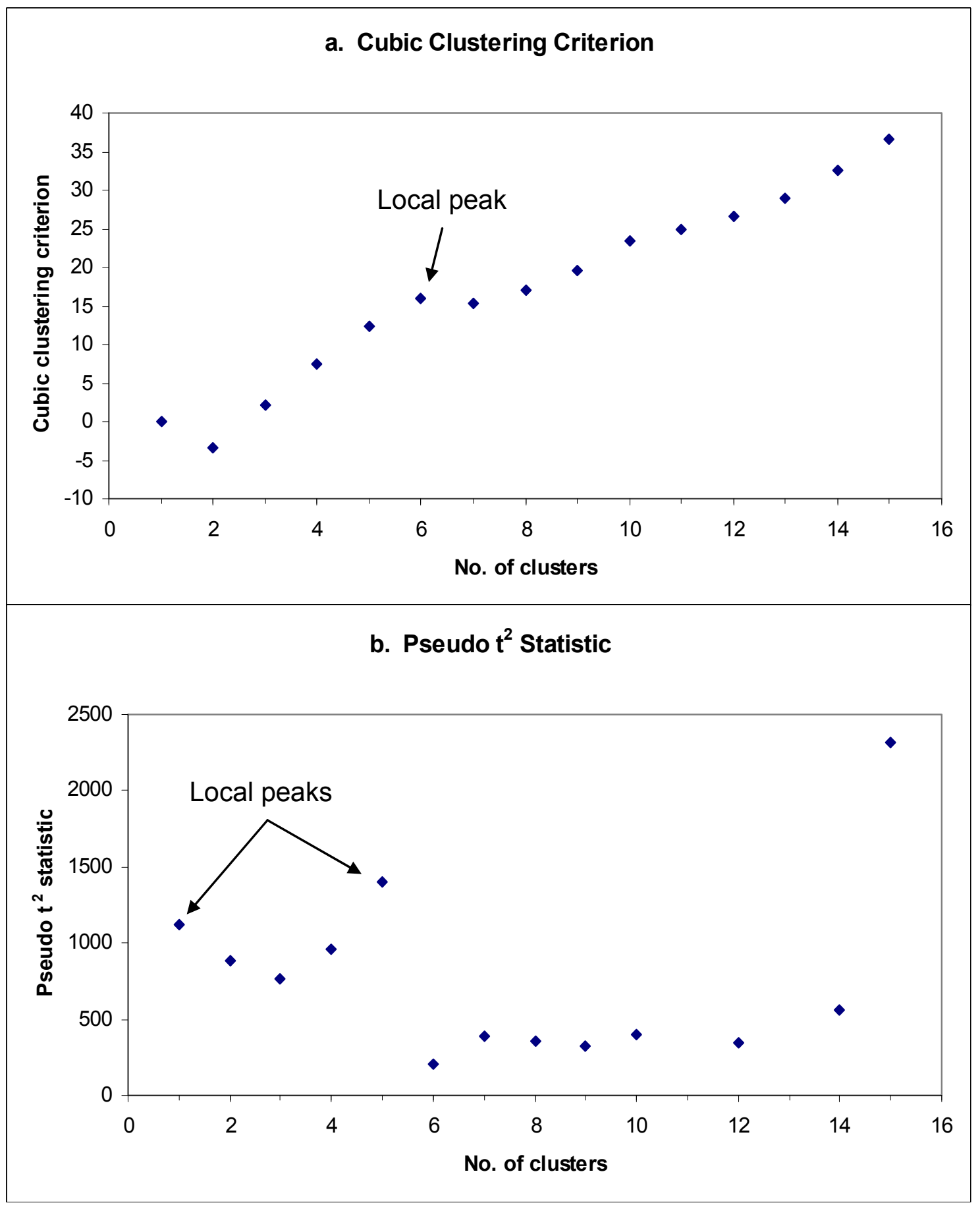

Figure 10. Graphs of (a) the cubic clustering criterion (CCC) and (b) the pseudo $\mathrm{t}^{2}$ (PST2) statistic. A peak in CCC values suggests six clusters, whereas local peaks in PST2 values suggest two or six clusters. 


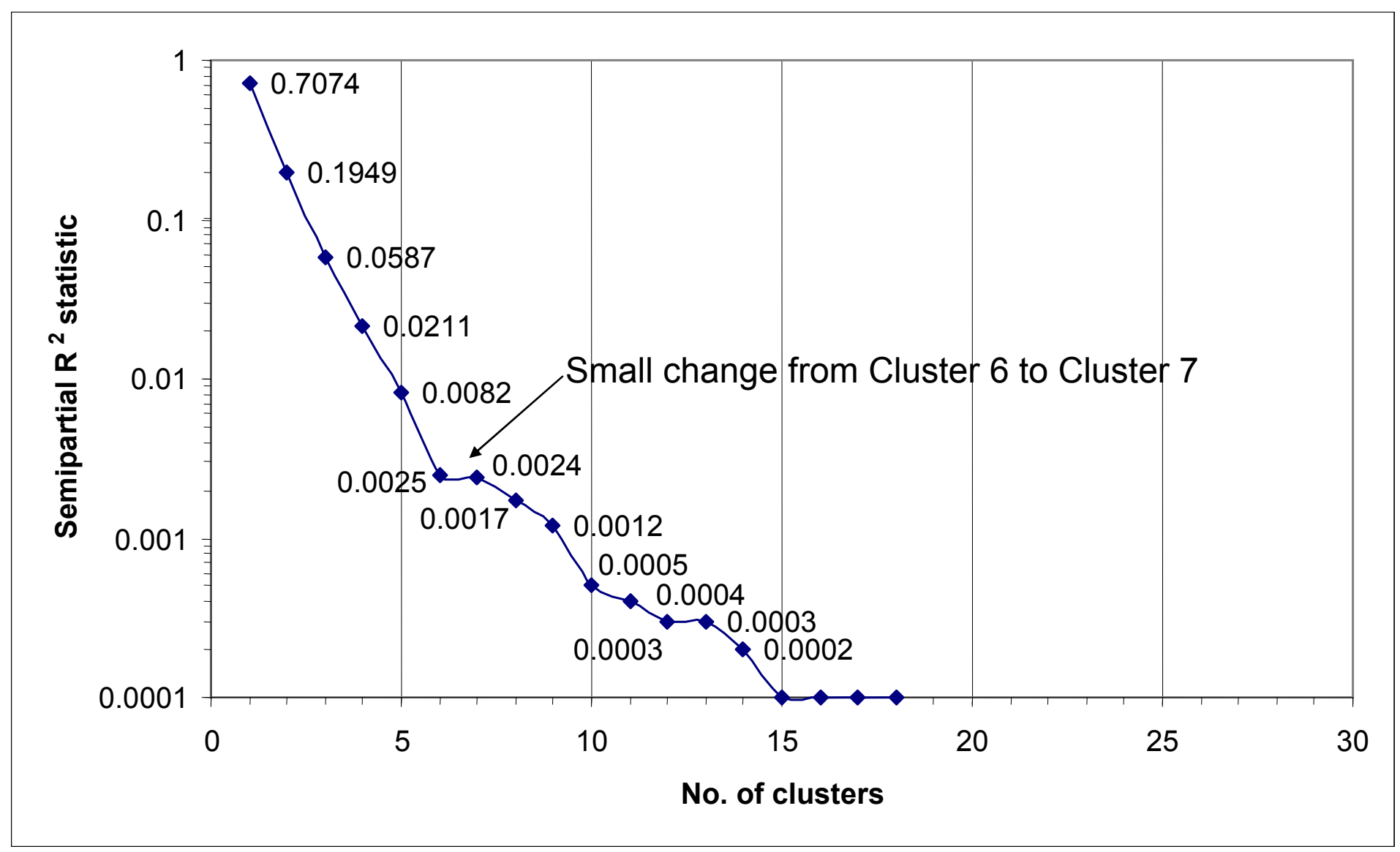

Figure 11. Graph of relation of semipartial $R^{2}$ (SPRSQ) statistics and number of clusters for total selenium concentrations in unfiltered water samples. Going from right to left, a sharp increase occurs between six clusters $(0.0025)$ and five clusters $(0.0082)$, suggesting that six clusters may be optimal. 


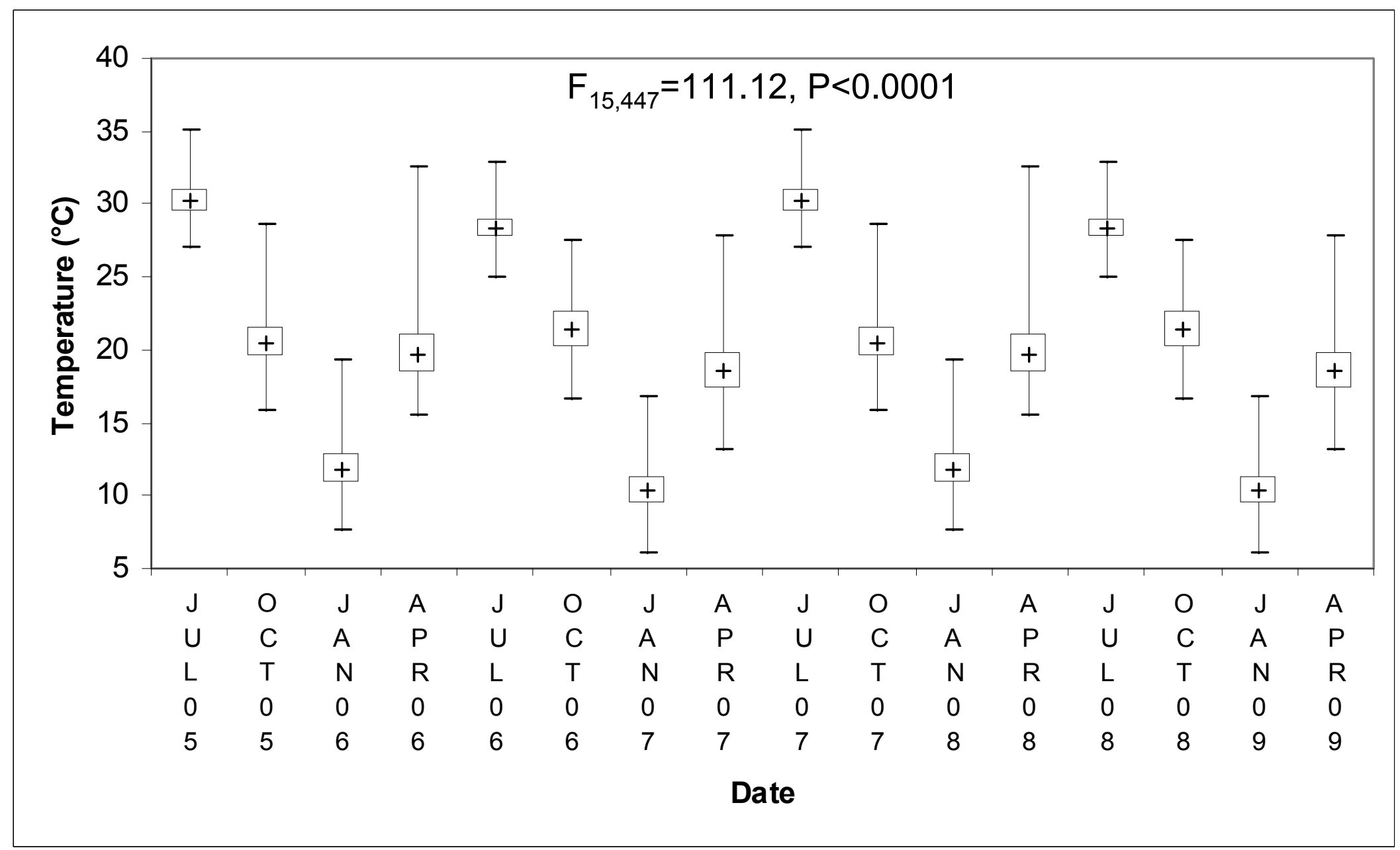

Figure 12. Boxplots of temperature in water measured on 16 sampling dates from 29 agricultural drains or ponds. Symbols are geometric means $(+)$, $95 \%$ confidence intervals (box), and minimum and maximum values (vertical lines). 


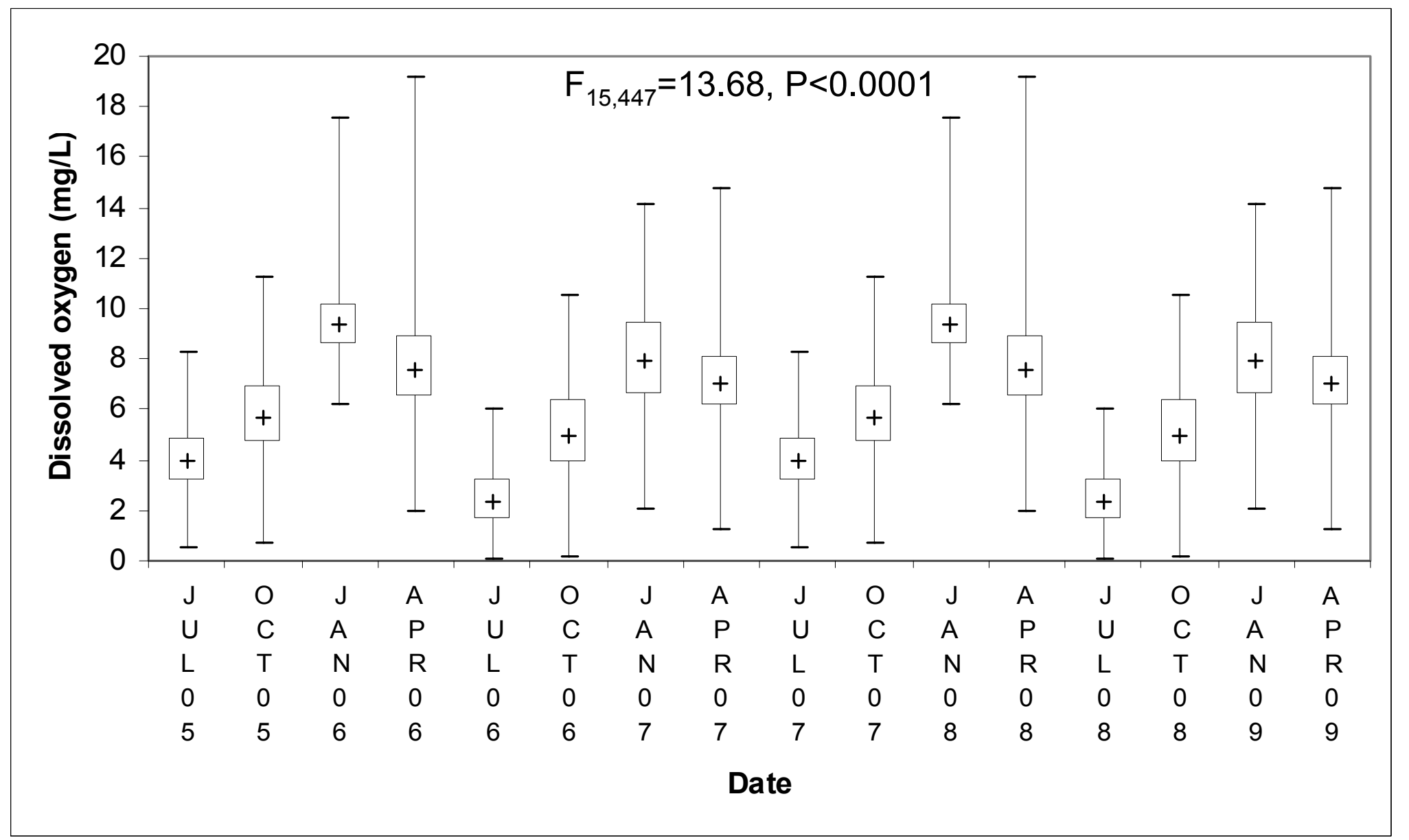

Figure 13. Boxplots of dissolved oxygen concentration in water measured on 16 sampling dates from 29 agricultural drains or ponds. Symbols are geometric means (+), 95\% confidence intervals (box), and minimum and maximum values (vertical lines). 


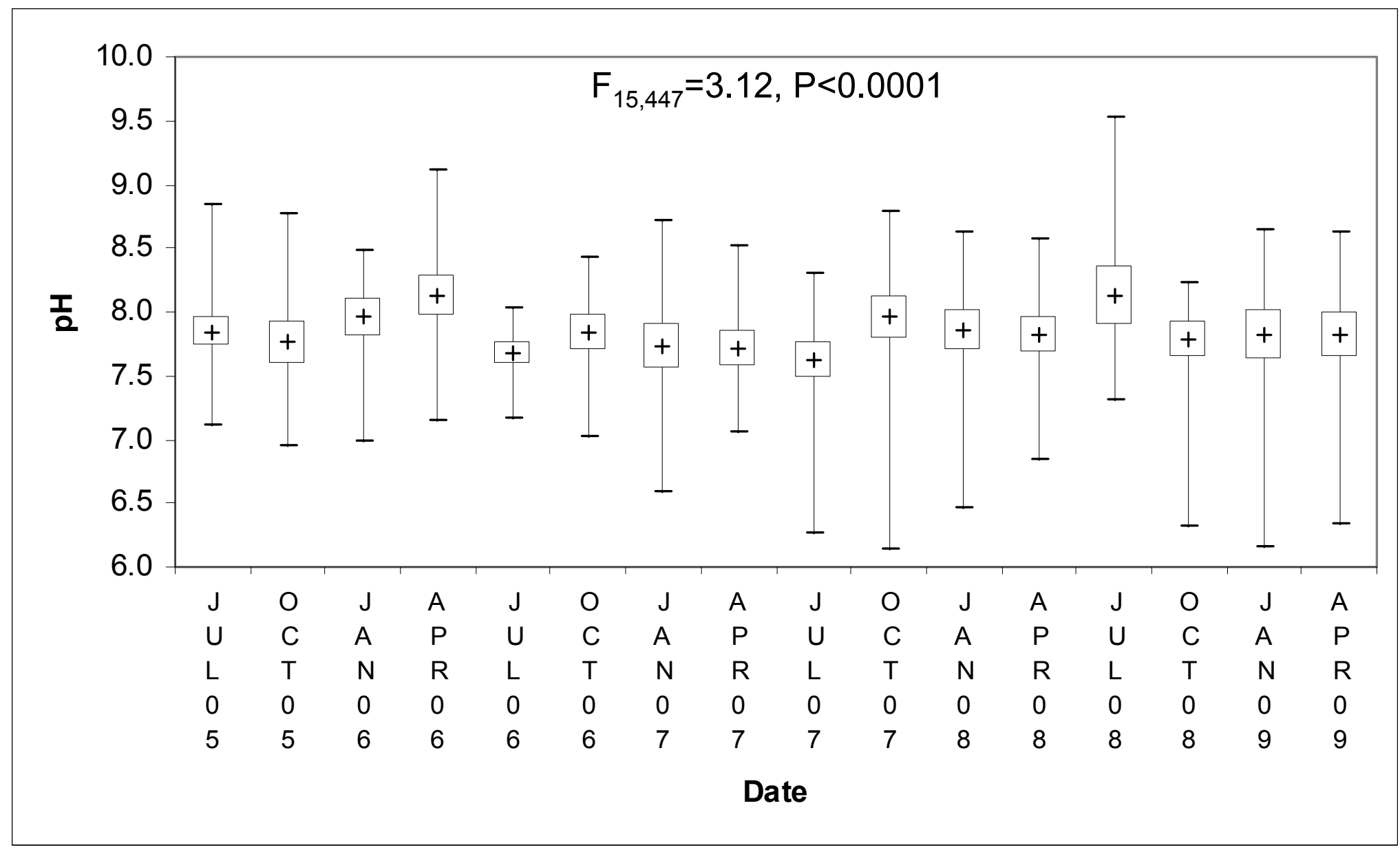

Figure 14. Boxplots of hydrogen-ion concentration $(\mathrm{pH})$ in water measured on 16 sampling dates from 29 agricultural drains or ponds. Symbols are arithmetic means $(+), 95 \%$ confidence intervals (box), and minimum and maximum values (vertical lines). 


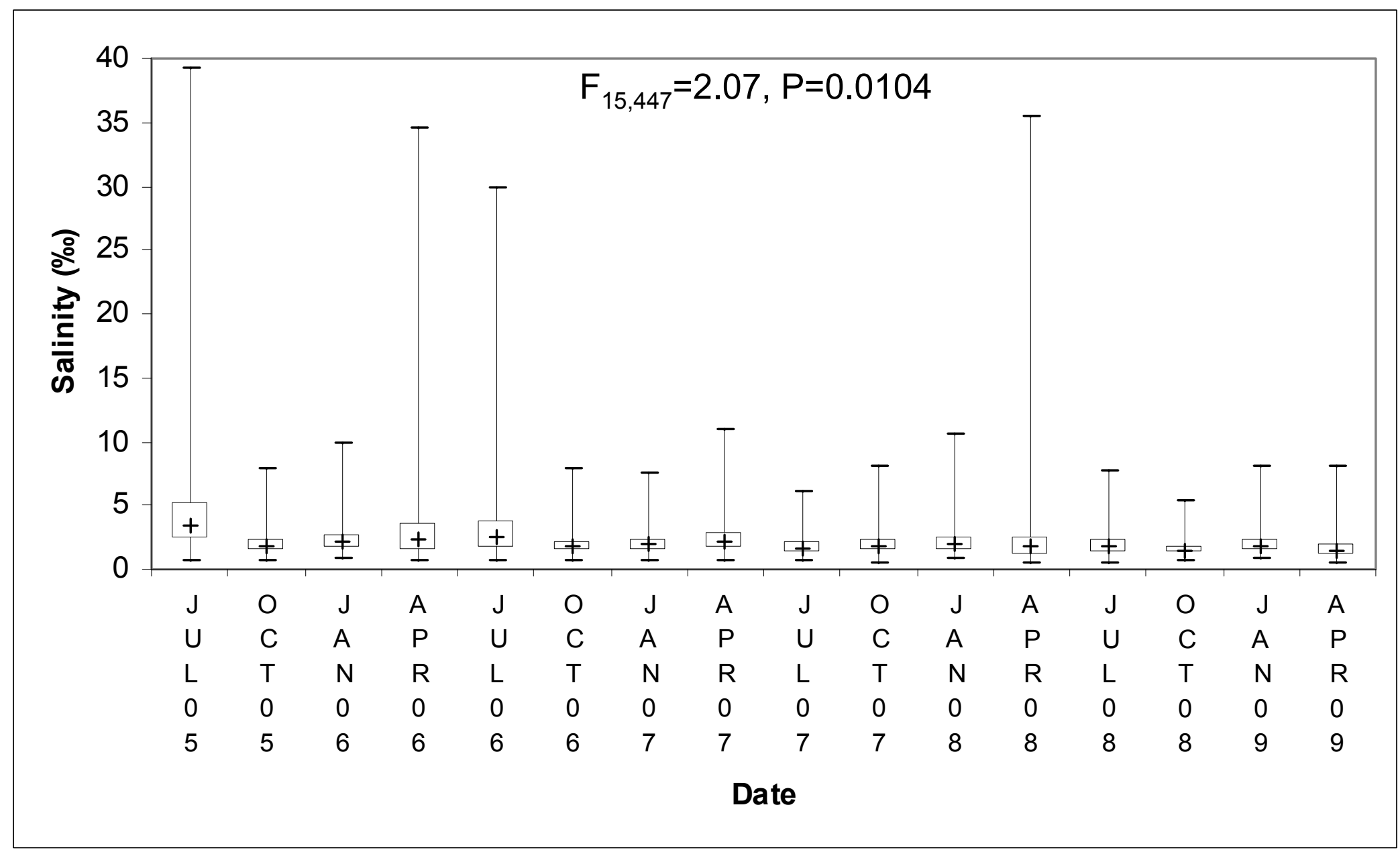

Figure 15. Boxplots of salinity concentration in water measured on 16 sampling dates from 29 agricultural drains or ponds. Symbols are geometric means (+), 95\% confidence intervals (box), and minimum and maximum values (vertical lines). 


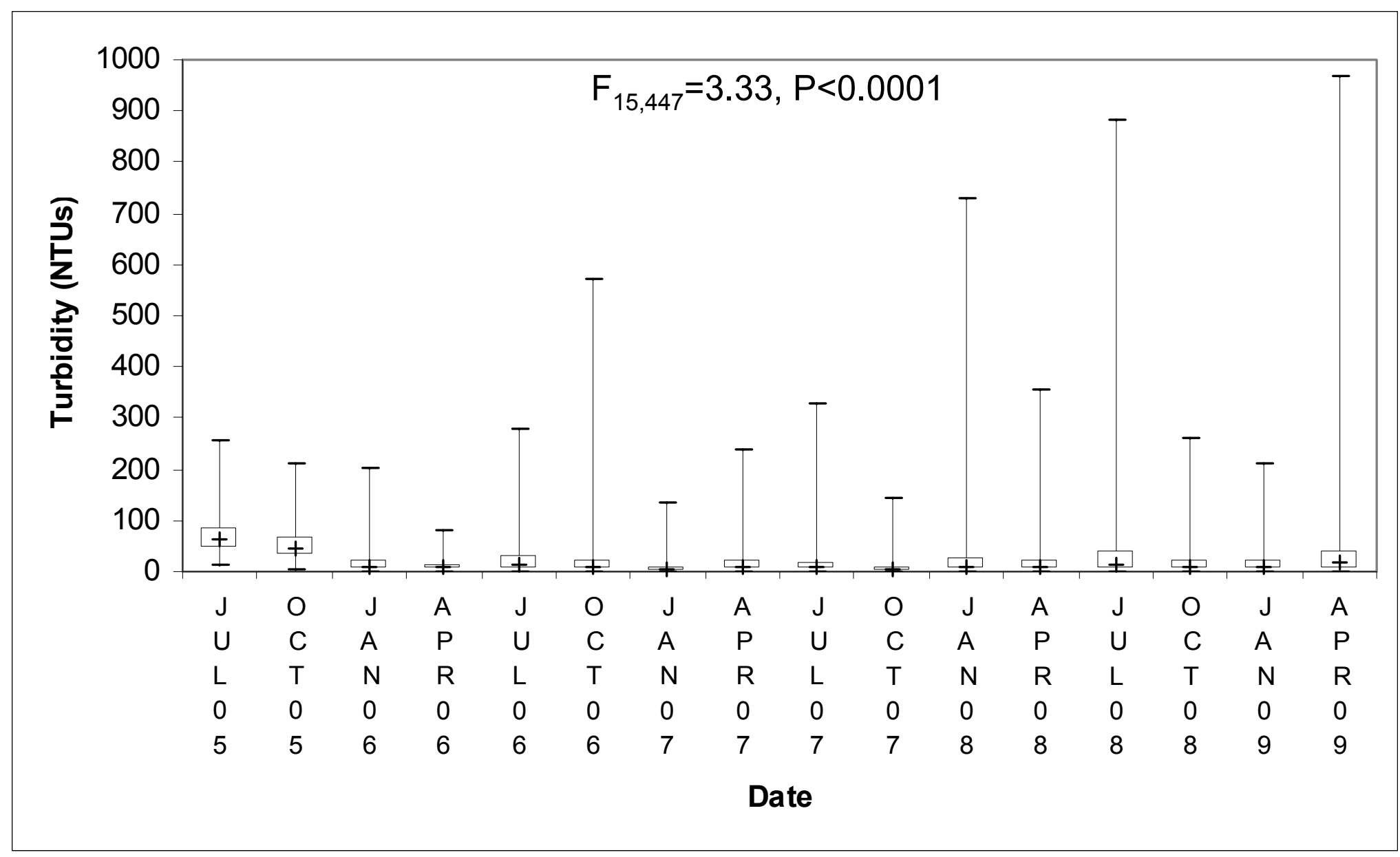

Figure 16. Boxplots of turbidity in water measured on 16 sampling dates from 29 agricultural drains or ponds. Symbols are geometric means $(+)$, $95 \%$ confidence intervals (box), and minimum and maximum values (vertical lines). 


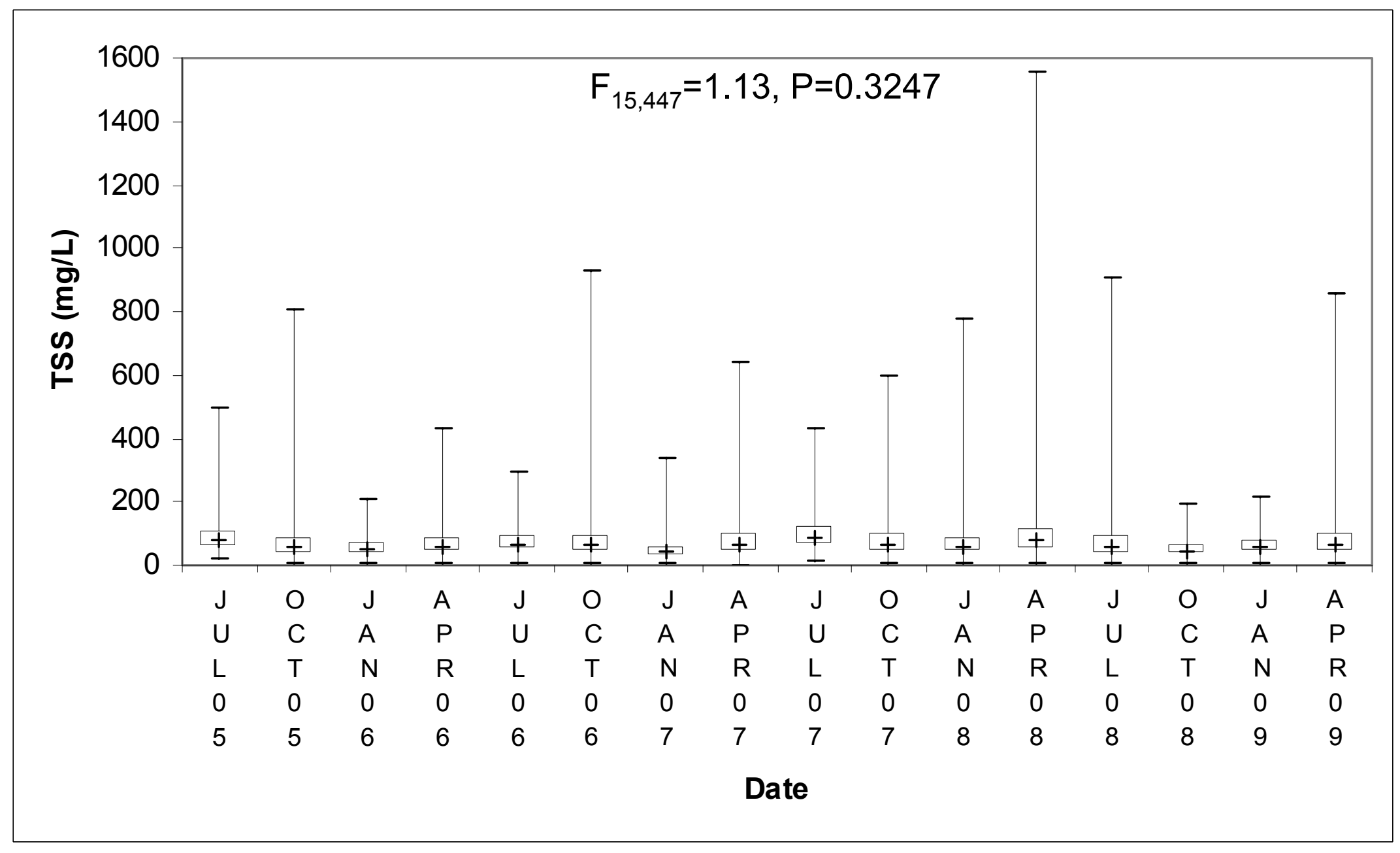

Figure 17. Boxplots of total suspended-solids concentration in water measured on 16 sampling dates from 29 agricultural drains or ponds. Symbols are geometric means $(+), 95 \%$ confidence intervals (box), and minimum and maximum values (vertical lines). 


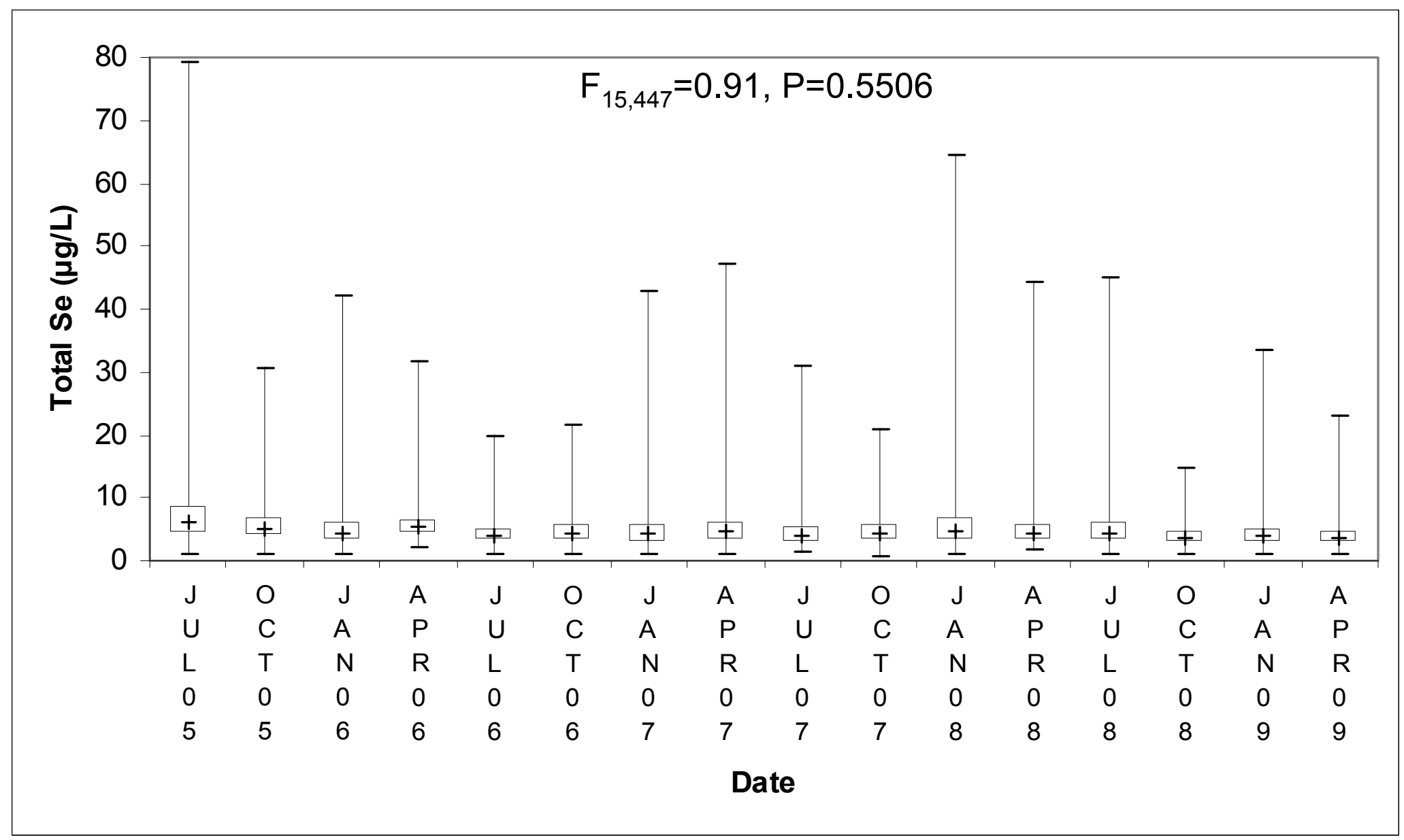

Figure 18. Boxplots of total selenium concentration in water measured on 16 sampling dates from 29 agricultural drains or ponds. Symbols are geometric means (+), 95\% confidence intervals (box), and minimum and maximum values (vertical lines). 


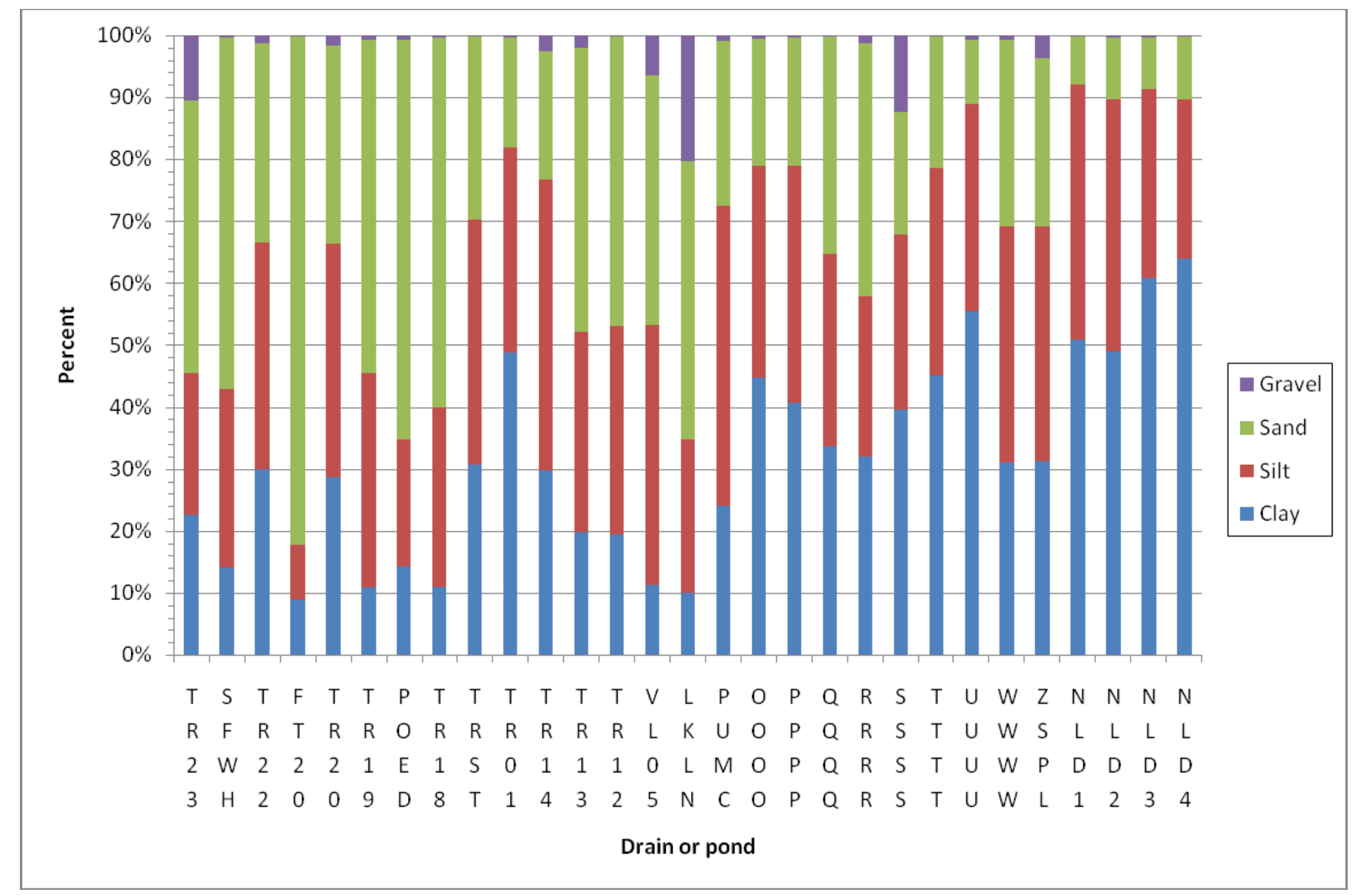

Figure 19. Graph showing particle-size distribution of sediment samples from 29 agricultural drains or ponds collected between April 2006 and April 2009. Twenty-nine drains and ponds were sampled during April of each year, whereas 7 of 29 drains were sampled during October of each year. Codes for drains and ponds are given in table 1. 


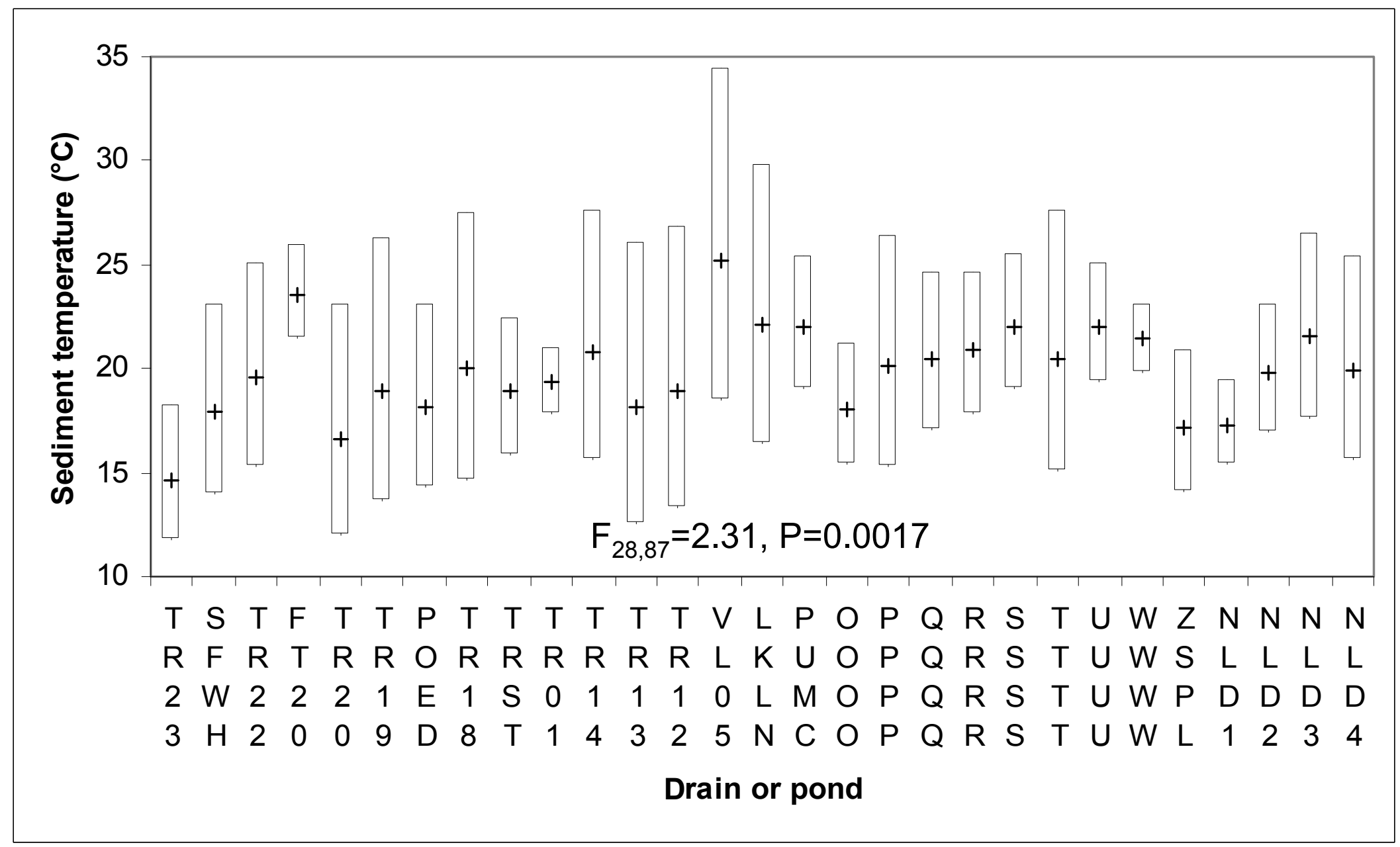

Figure 20. Boxplots of temperature in sediment samples from 29 agricultural drains and ponds collected during April 2006, April 2007, April 2008, and April 2009. Symbols are geometric means (+) and 95\% confidence intervals (box); minimum and maximum values (vertical lines) are mostly hidden by the confidence intervals. 


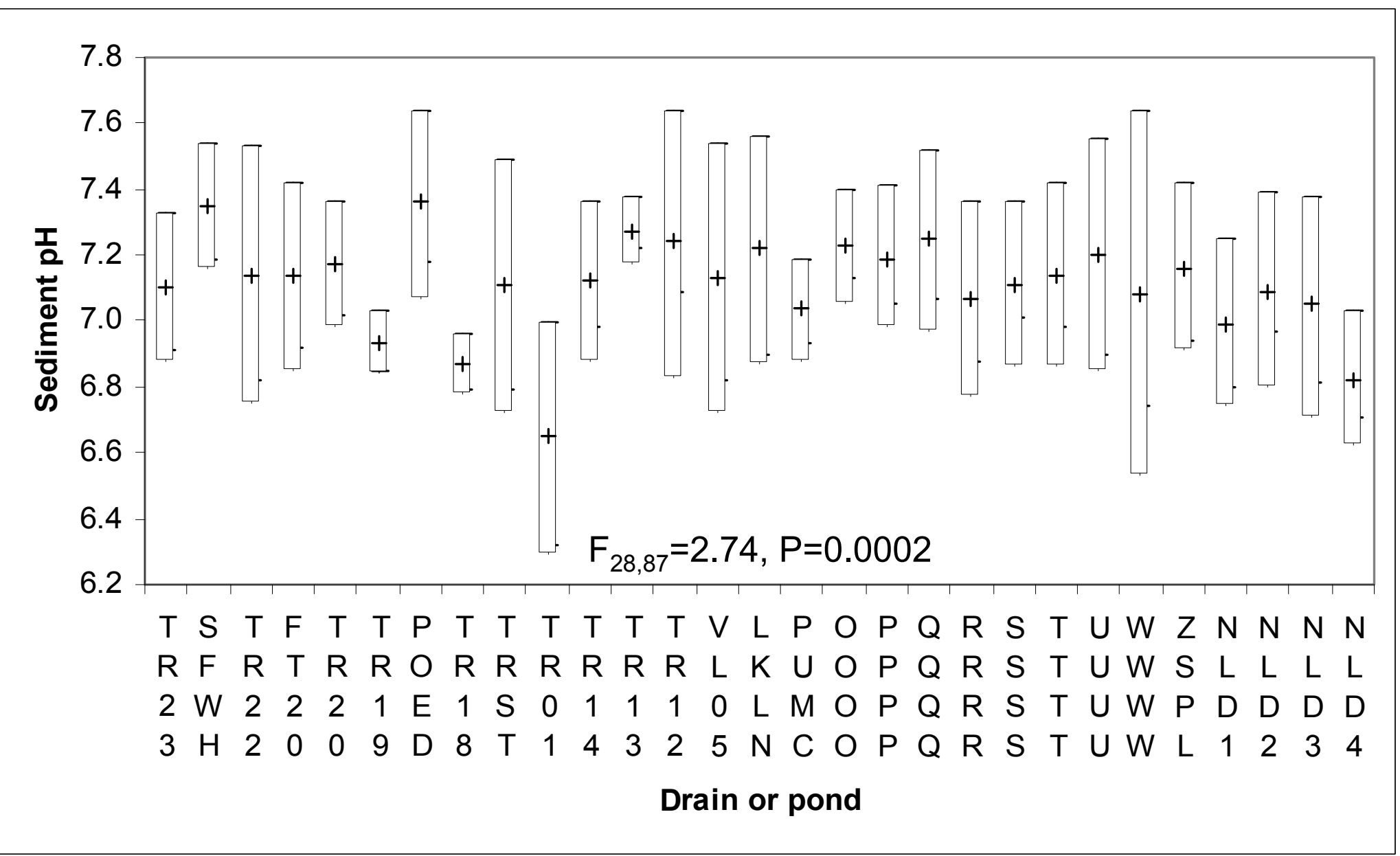

Figure 21. Boxplots of hydrogen-ion concentration $(\mathrm{pH})$ in sediment samples from 29 agricultural drains and ponds collected during April 2006, April 2007, April 2008, and April 2009. Symbols are arithmetic means (+) and 95\% confidence intervals (box); minimum and maximum values (vertical lines) are mostly hidden by the confidence intervals. 


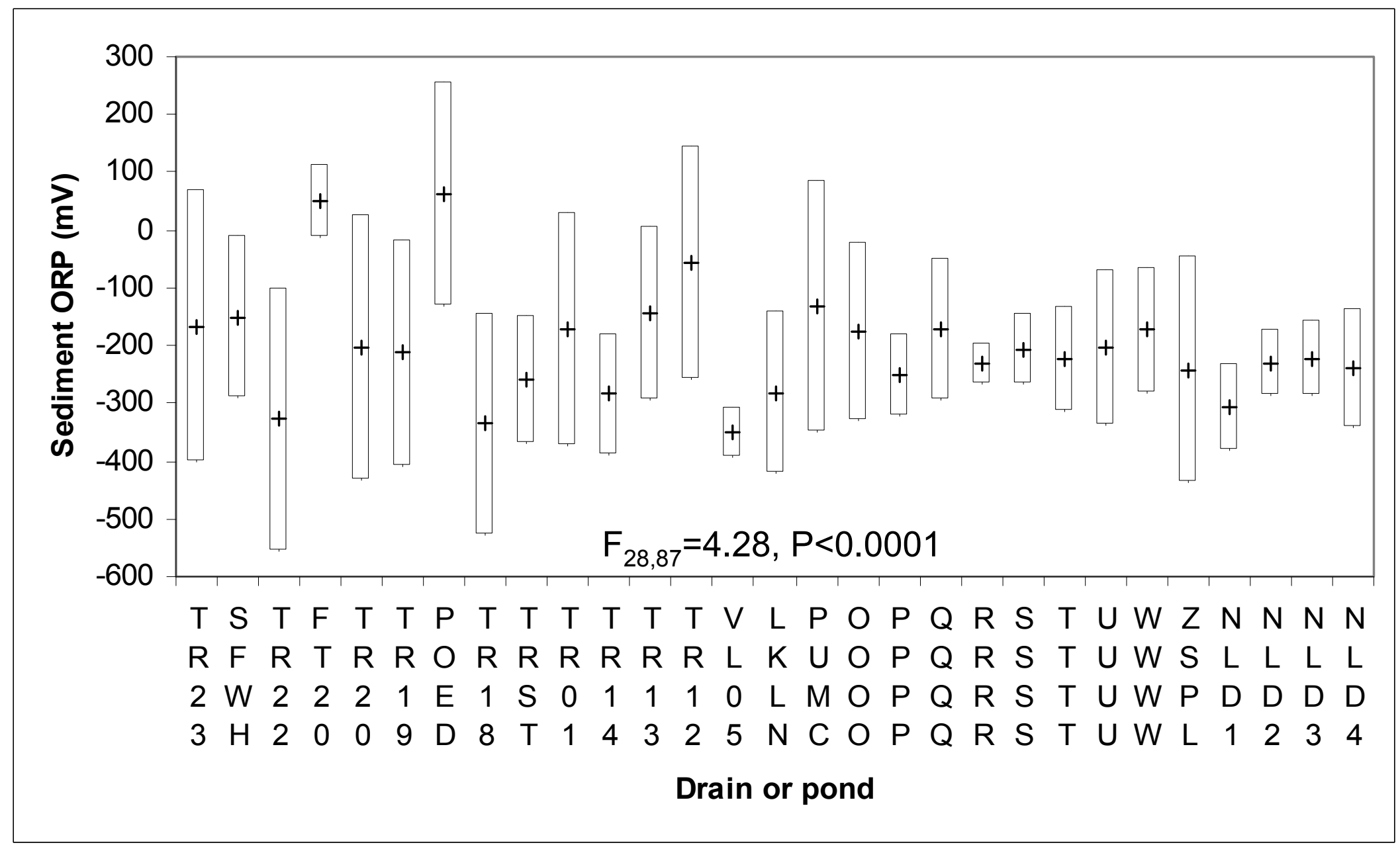

Figure 22. Boxplots of oxidation-reduction potential in sediment samples from 29 agricultural drains and ponds collected during April 2006, April 2007, April 2008, and April 2009. Symbols are geometric means (+) and 95\% confidence intervals (box); minimum and maximum values (vertical lines) are mostly hidden by the confidence intervals. 


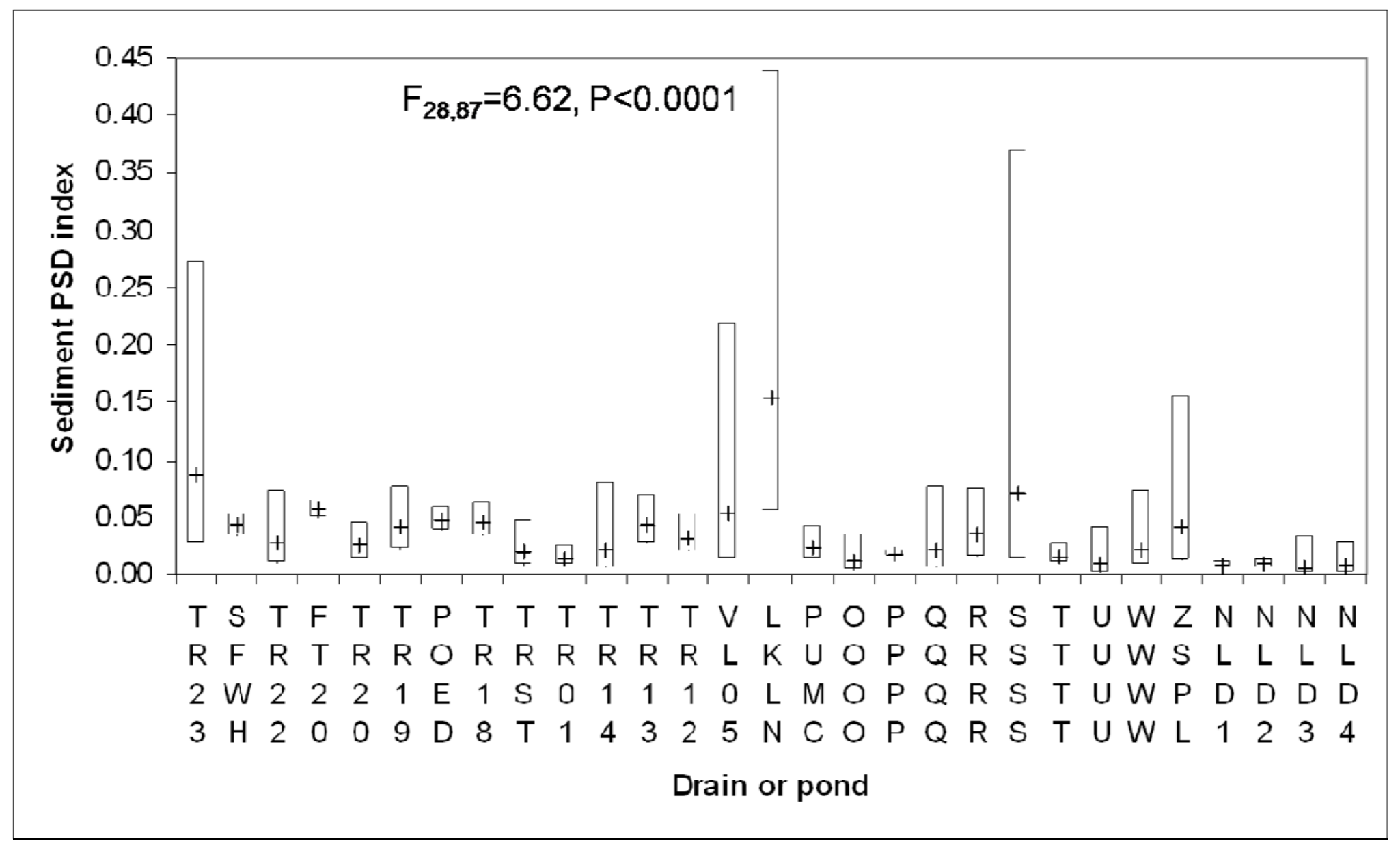

Figure 23. Boxplots of Schoklitsch $s$ (also referred to as "particle-size distribution index") in sediment samples from 29 agricultural drains and ponds collected during April 2006, April 2007, April 2008, and April 2009. Symbols are geometric means (+) and 95\% confidence intervals (box); minimum and maximum values (vertical lines) are mostly hidden by the confidence intervals. 


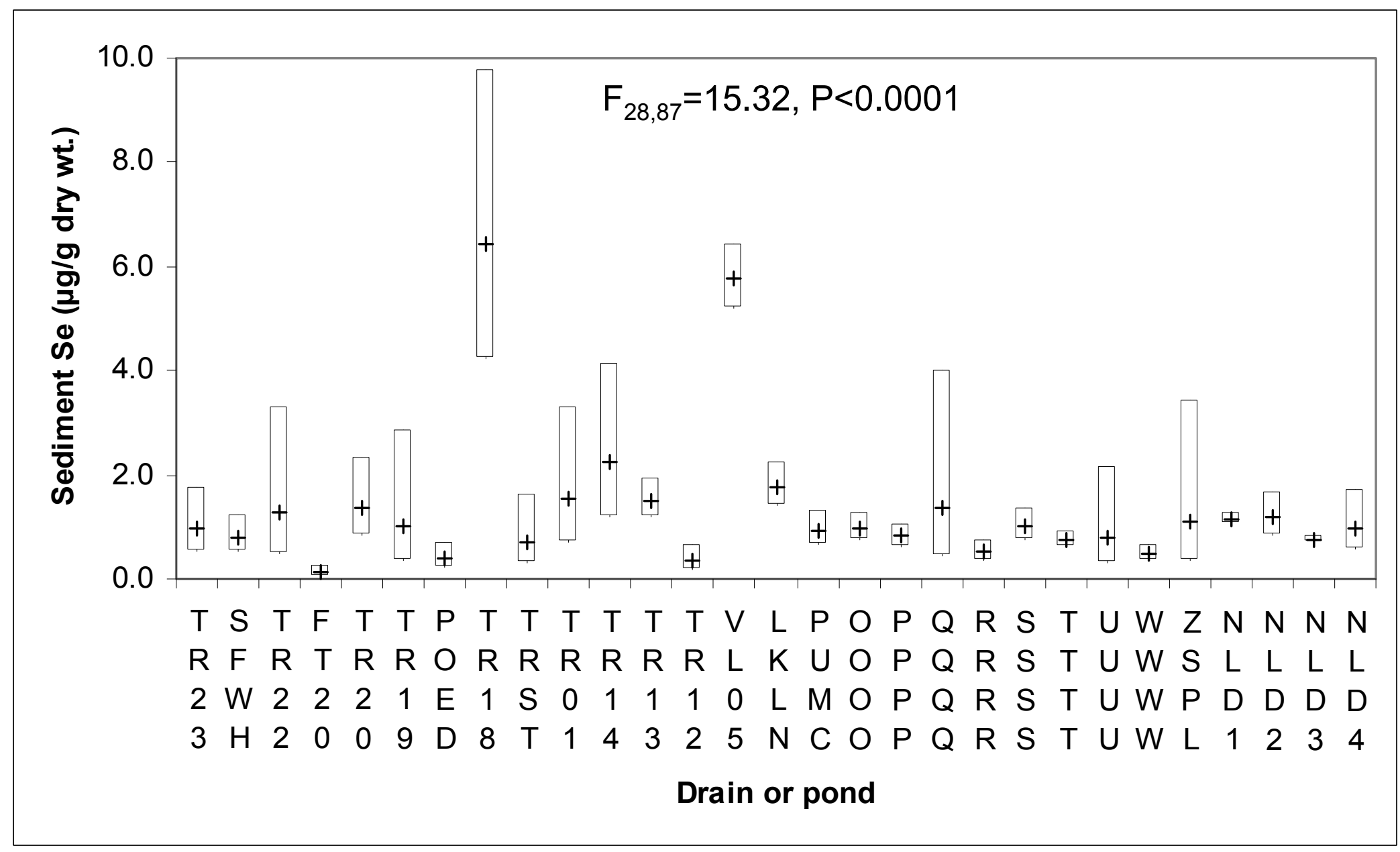

Figure 24. Boxplots of total selenium concentration in sediment samples from 29 agricultural drains and ponds collected during April 2006, April 2007, April 2008, and April 2009. Symbols are geometric means $(+$ ) and $95 \%$ confidence intervals (box); minimum and maximum values (vertical lines) are mostly hidden by the confidence intervals. 


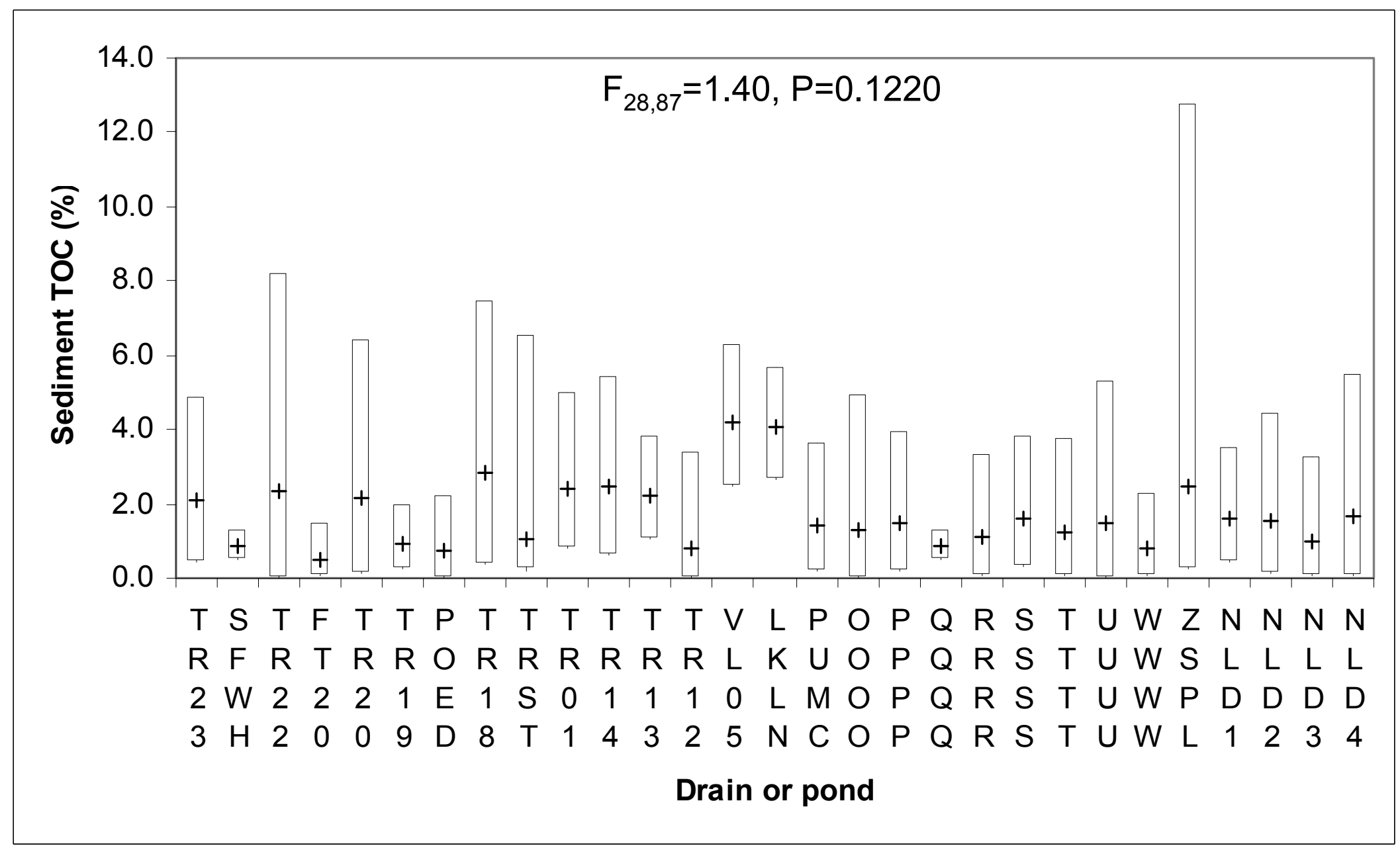

Figure 25. Boxplots of total organic carbon content in sediment samples from 29 agricultural drains and ponds collected during April 2006, April 2007, April 2008, and April 2009. Symbols are back-transformed angular means (+) and $95 \%$ confidence intervals (box); minimum and maximum values (vertical lines) are mostly hidden by the confidence intervals. 


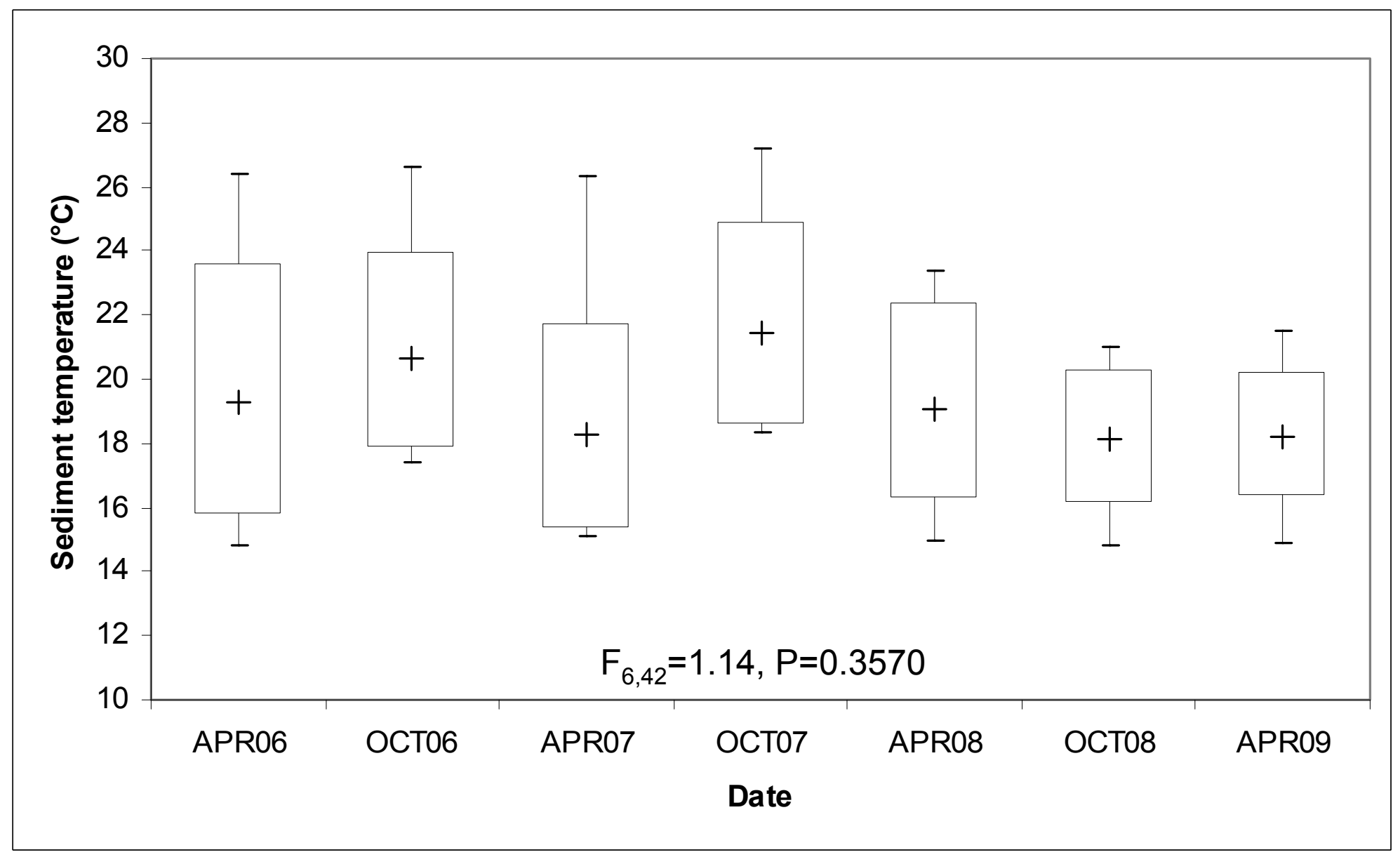

Figure 26. Boxplots of temperature in sediment samples collected on seven sampling dates from agricultural drains: Trifolium 20, Poe, Trifolium 18, Trifolium 14, O, T, and Z-Spill. Symbols are geometric means (+), 95\% confidence intervals (box), and minimum and maximum values (vertical lines). 


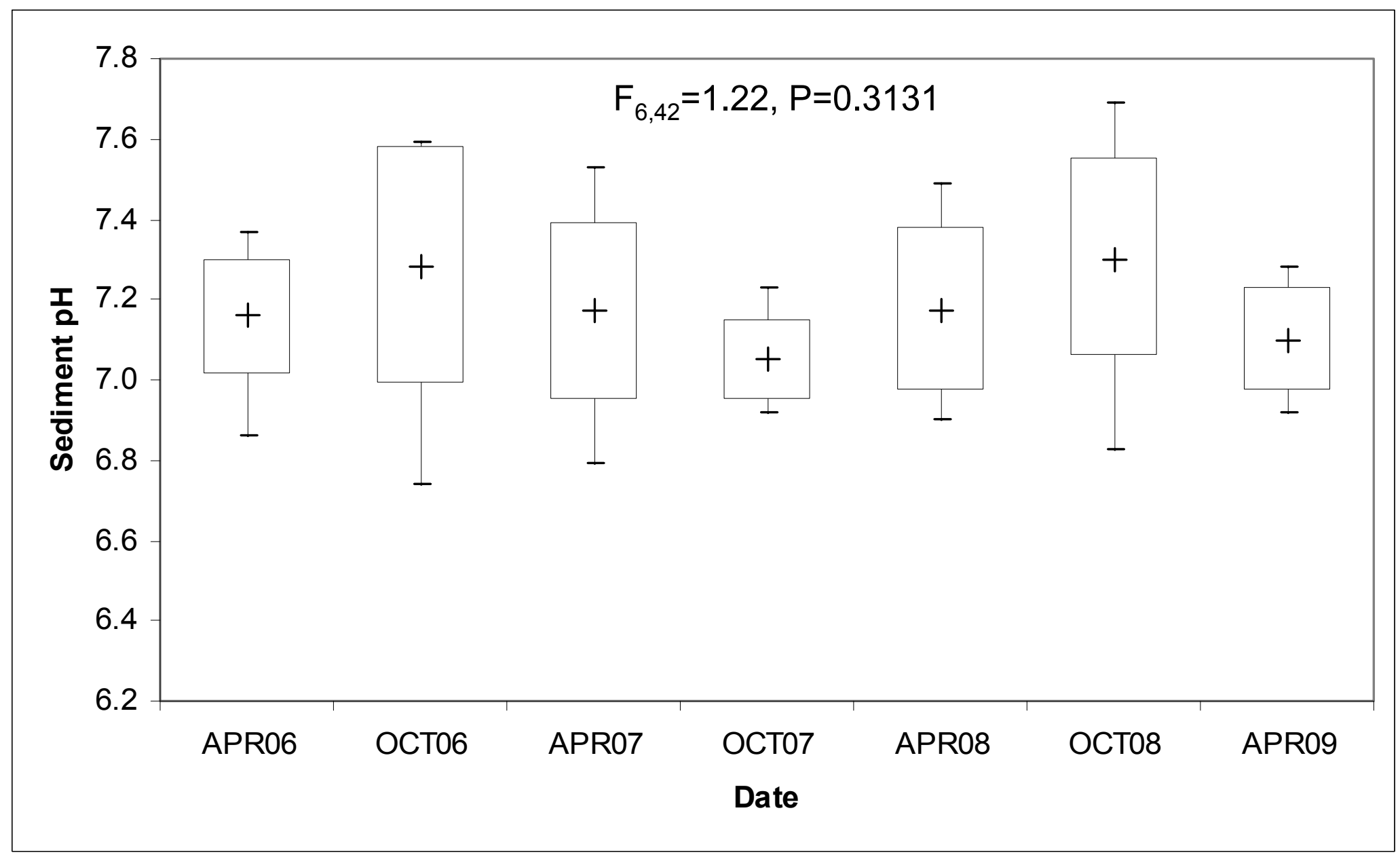

Figure 27. Boxplots of hydrogen-ion concentration $(\mathrm{pH})$ in sediment samples collected on seven sampling dates from agricultural drains: Trifolium 20, Poe, Trifolium 18, Trifolium 14, 0, T, and Z-Spill. Symbols are arithmetic means (+), 95\% confidence intervals (box), and minimum and maximum values (vertical lines). 


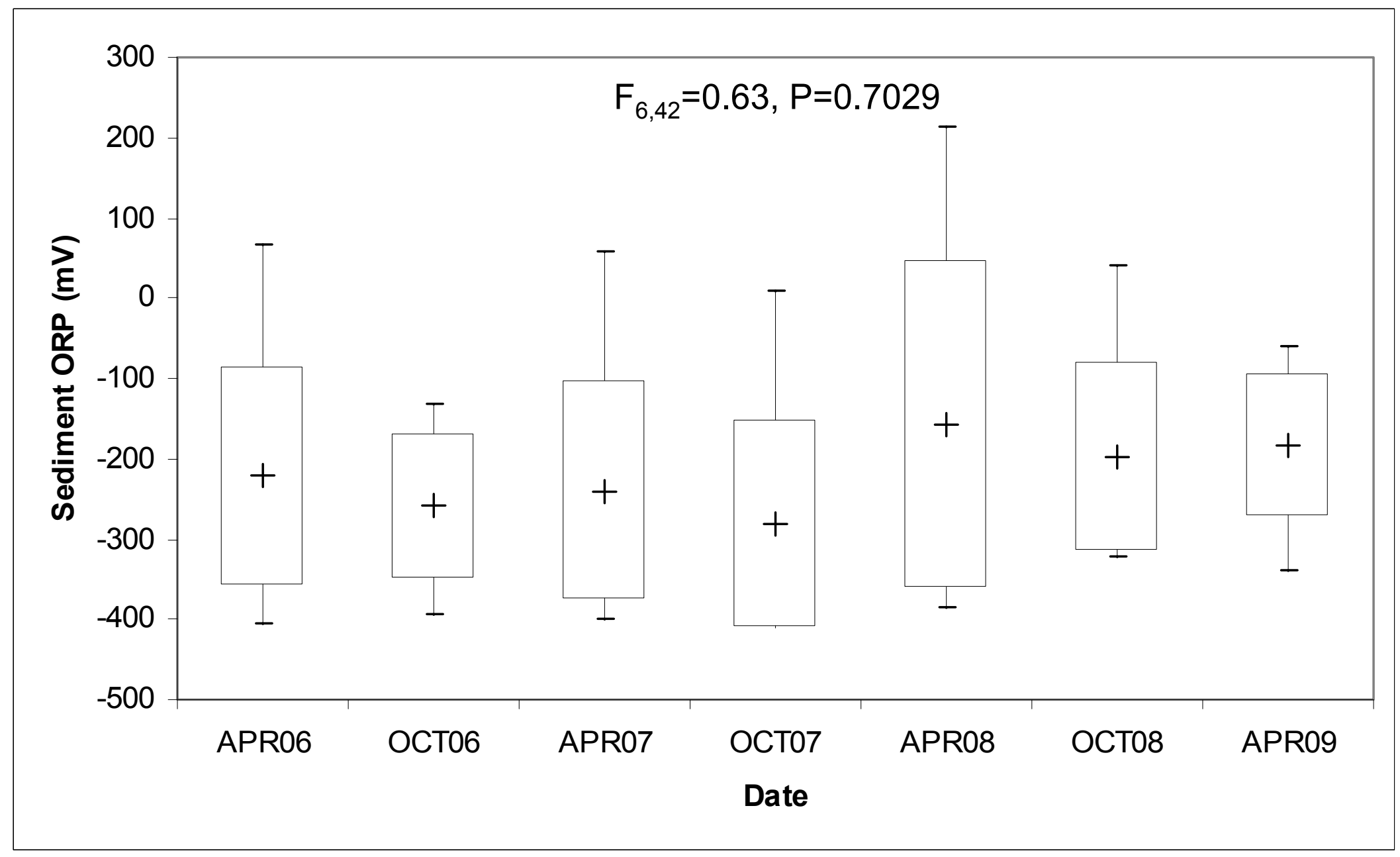

Figure 28. Boxplots of oxidation-reduction potential in sediment samples collected on seven sampling dates from agricultural drains: Trifolium 20, Poe, Trifolium 18, Trifolium 14, O, T, and Z-Spill. Symbols are arithmetic means (+), 95\% confidence intervals (box), and minimum and maximum values (vertical lines). 


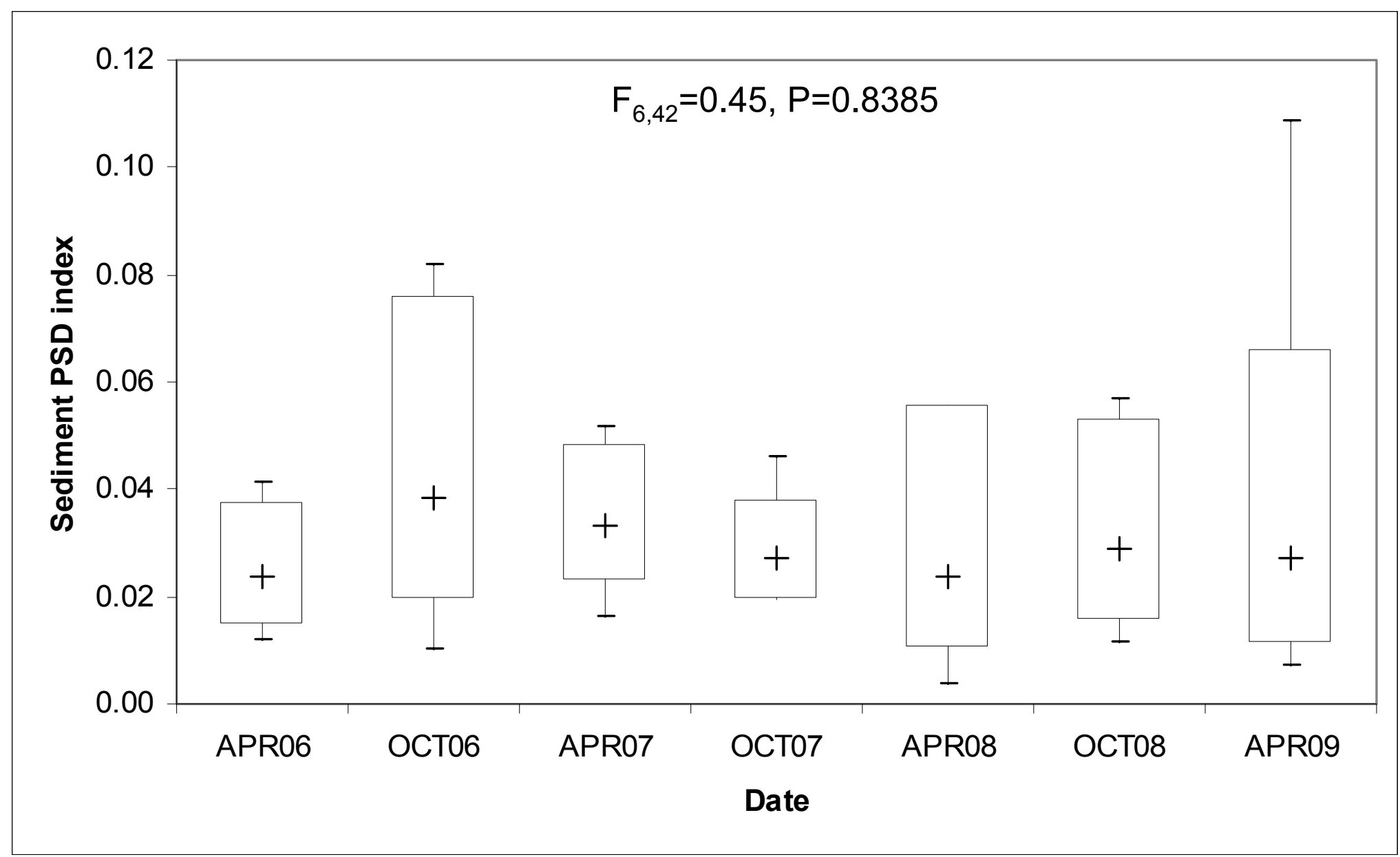

Figure 29. Boxplots of Schoklitsch $\boldsymbol{s}$ (also referred to as "sediment particle size index") in sediment samples collected on seven sampling dates from agricultural drains: Trifolium 20, Poe, Trifolium 18, Trifolium 14, O, T, and Z-Spill. Symbols are geometric means (+), 95\% confidence intervals (box), and minimum and maximum values (vertical lines). 


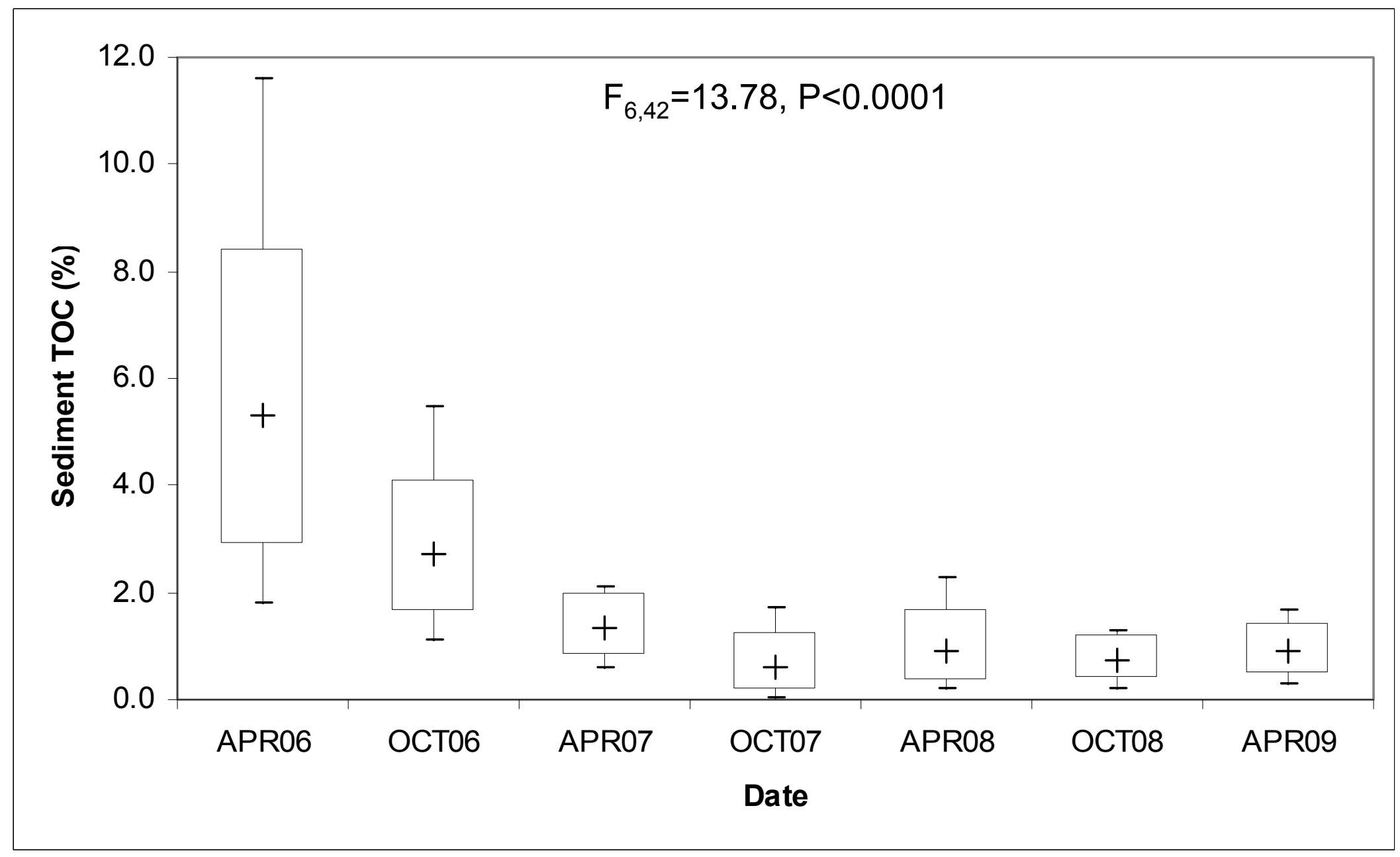

Figure 30. Boxplots of total organic carbon content in sediment samples collected on seven sampling dates from agricultural drains: Trifolium 20, Poe, Trifolium 18, Trifolium 14, O, T, and Z-Spill. Symbols are back-transformed angular means $(+), 95 \%$ confidence intervals (box), and minimum and maximum values (vertical lines). 


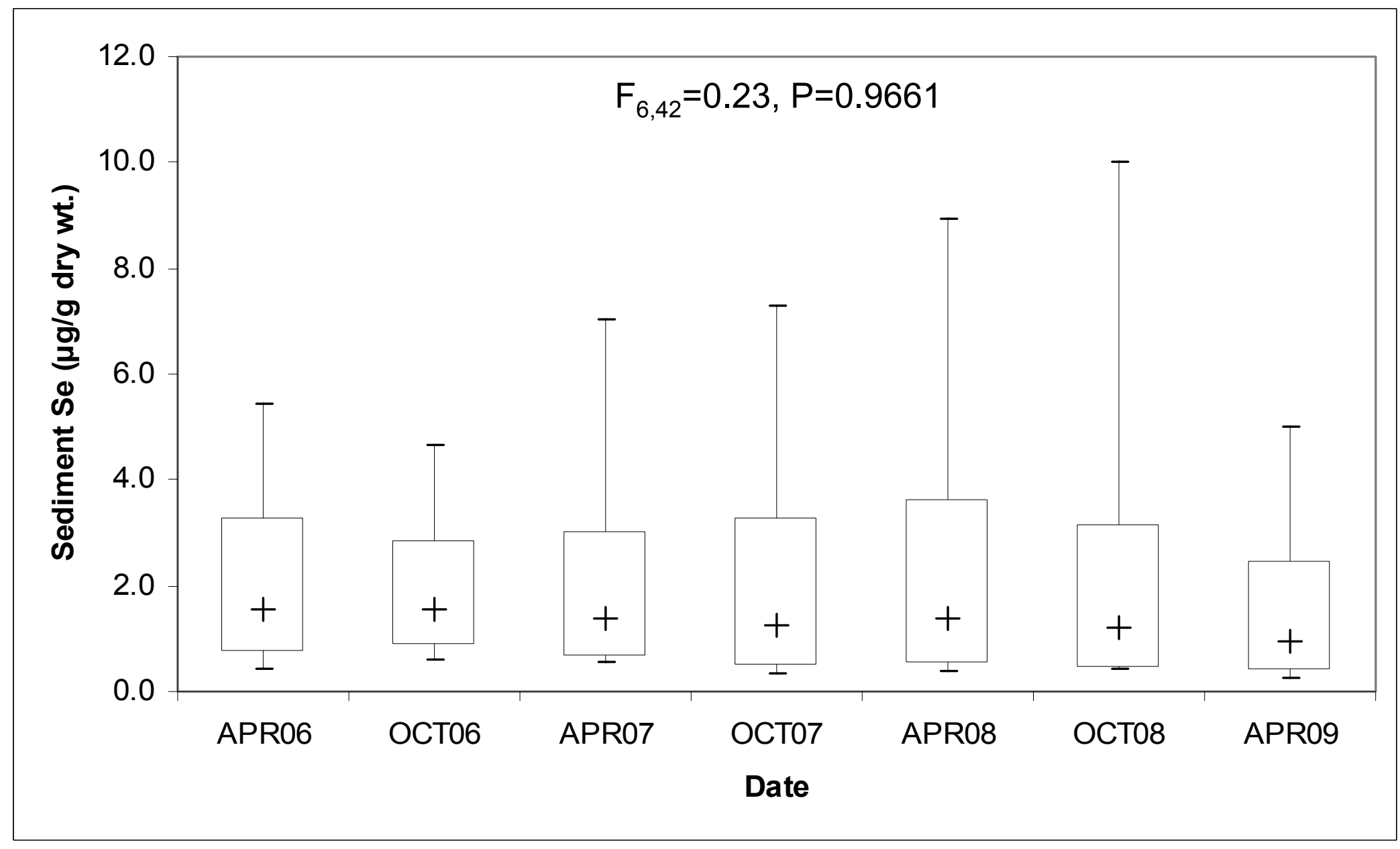

Figure 31. Boxplots of total selenium concentration in sediment samples collected on seven sampling dates from agricultural drains: Trifolium 20, Poe, Trifolium 18, Trifolium 14, O, T, and Z-Spill. Symbols are geometric means (+), 95\% confidence intervals (box), and minimum and maximum values (vertical lines). 


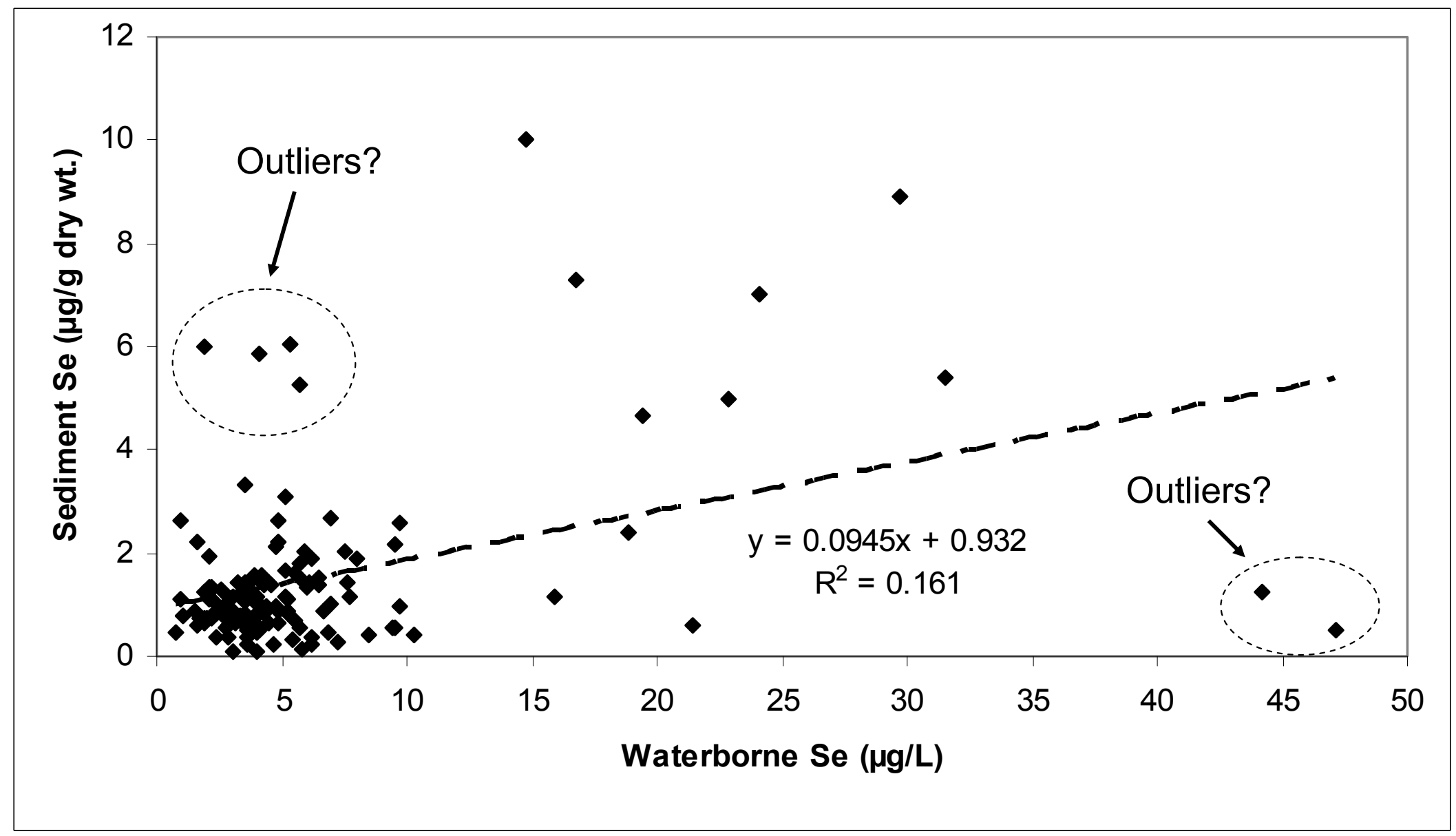

Figure 32. Graph of selenium concentrations in sediment samples and unfiltered water samples from 29 drains and ponds during April 2006-09, and from seven drains during October 2006-08. Several outlier values resulted from temporally fluctuating waterborne selenium concentrations. Linear regression with untransformed data resulted in a larger $\mathrm{R}^{2}$ value $(0.161)$ than a similar equation computed with logarithmically transformed data $\left(R^{2}=0.082\right)$. 


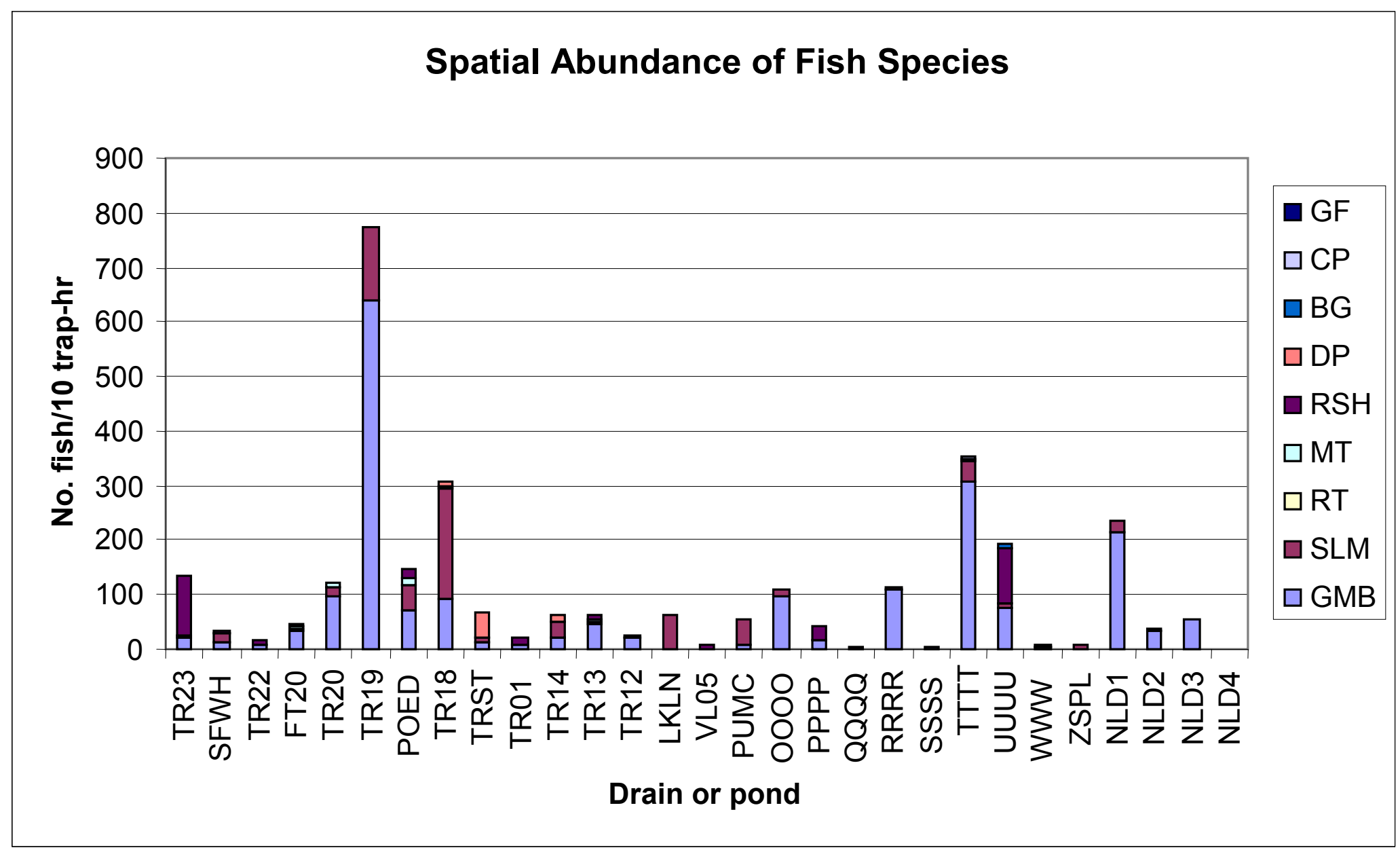

Figure 33. Graph of abundance (as catch-per-unit-effort) of western mosquitofish (GMB), sailfin molly (SLM), redbelly tilapia (RT), hybrid Mozambique tilapia (MT), red shiner (RSH), desert pupfish (DP), bluegill (BG), common carp (CP), and goldfish (GF) in 29 agricultural drains and ponds. Codes for drains or ponds are given in table 1. 


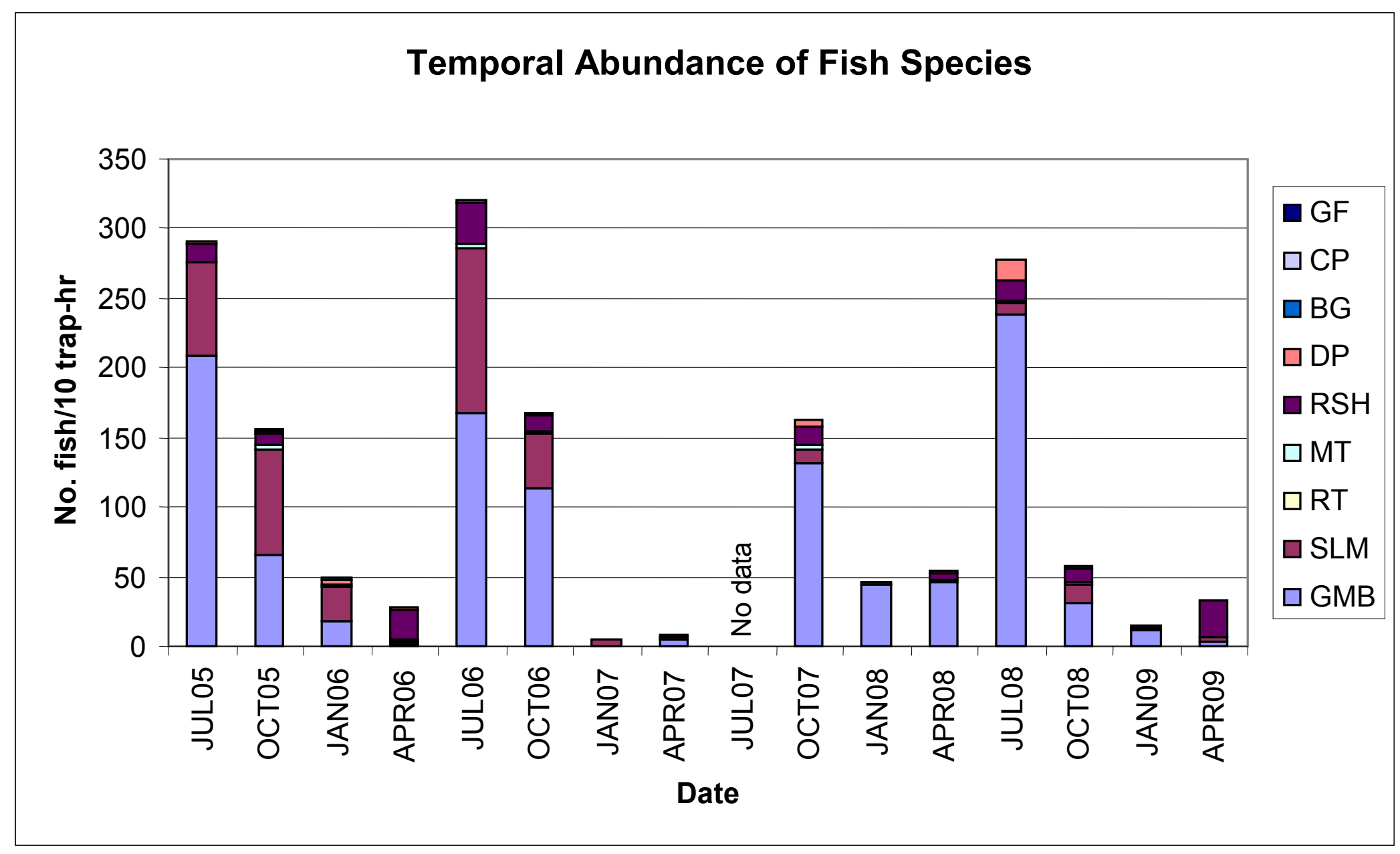

Figure 34. Graph of abundance (as catch-per-unit-effort) of western mosquitofish (GMB), sailfin molly (SLM), redbelly tilapia (RT), hybrid Mozambique tilapia (MT), red shiner (RSH), desert pupfish (DP), bluegill (BG), common carp (CP), and goldfish (GF) on 15 sampling dates. 


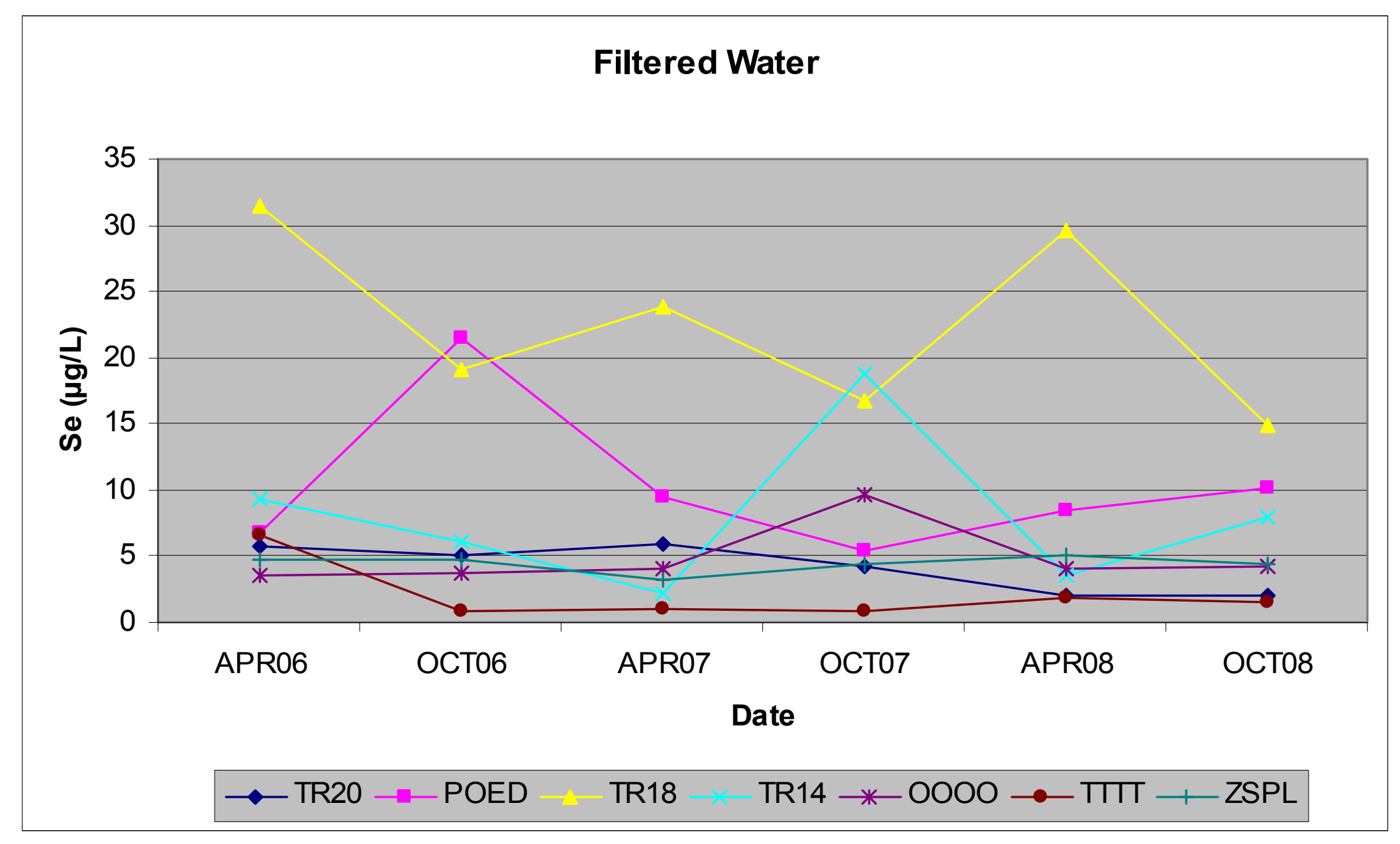

Figure 35. Graph of sampling dates and selenium concentrations in filtered water from seven agricultural drains. Codes for drains are given in table 1. 


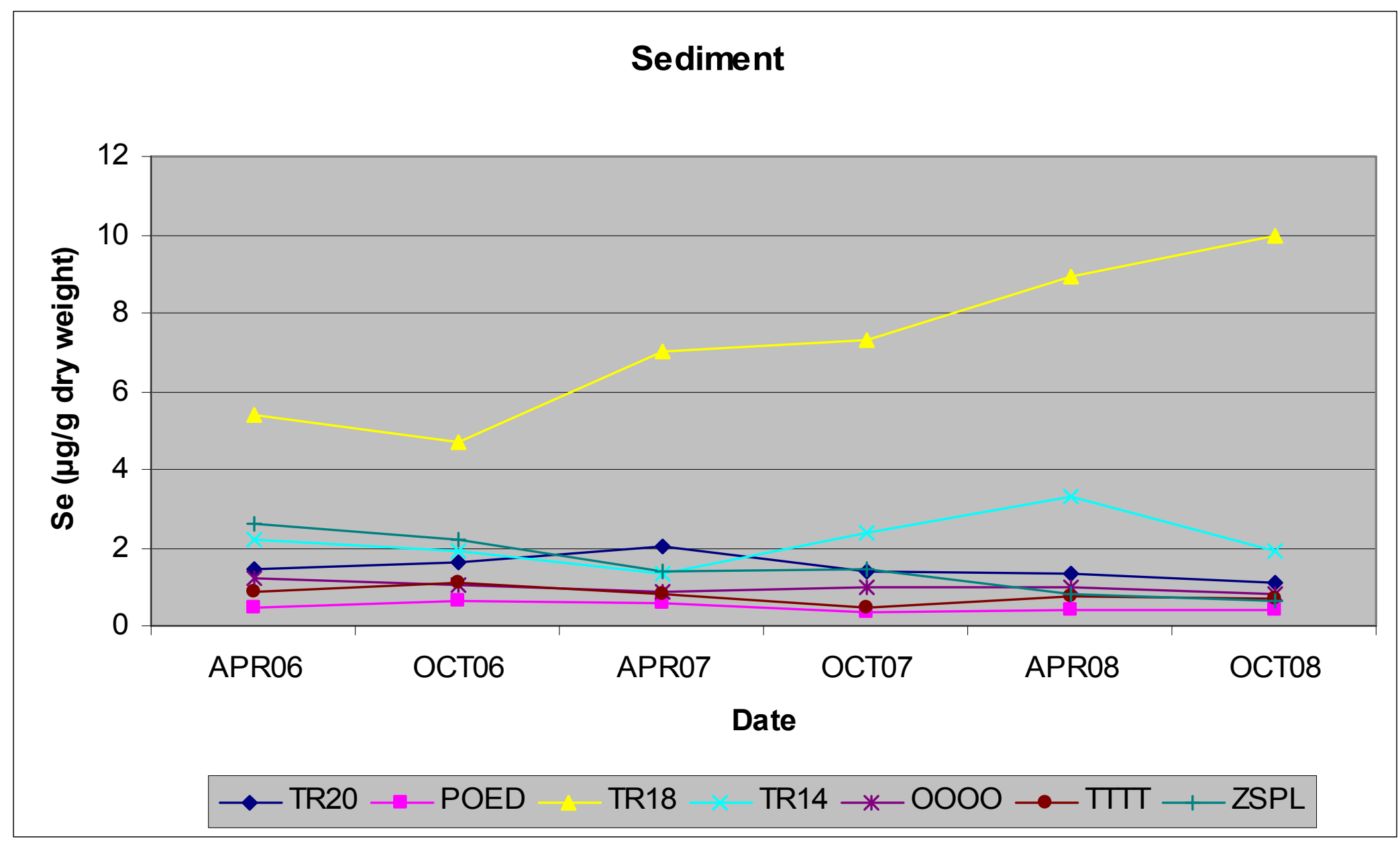

Figure 36. Graph of sampling dates and selenium concentrations in sediment from seven agricultural drains. Codes for drains are given in table 1. 


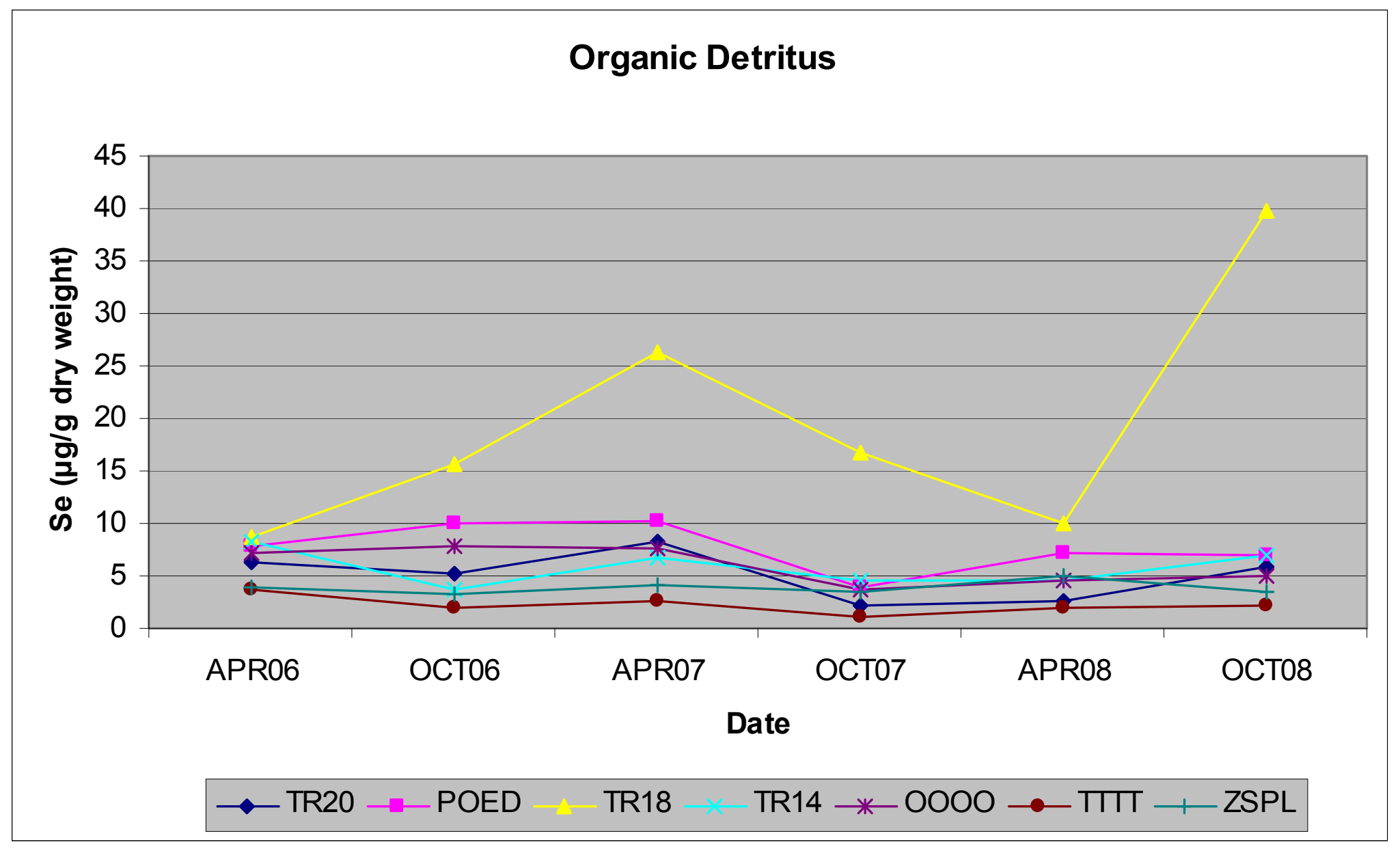

Figure 37. Graph of sampling dates and selenium concentrations in particulate organic detritus from seven agricultural drains. Codes for drains are given in table 1. 


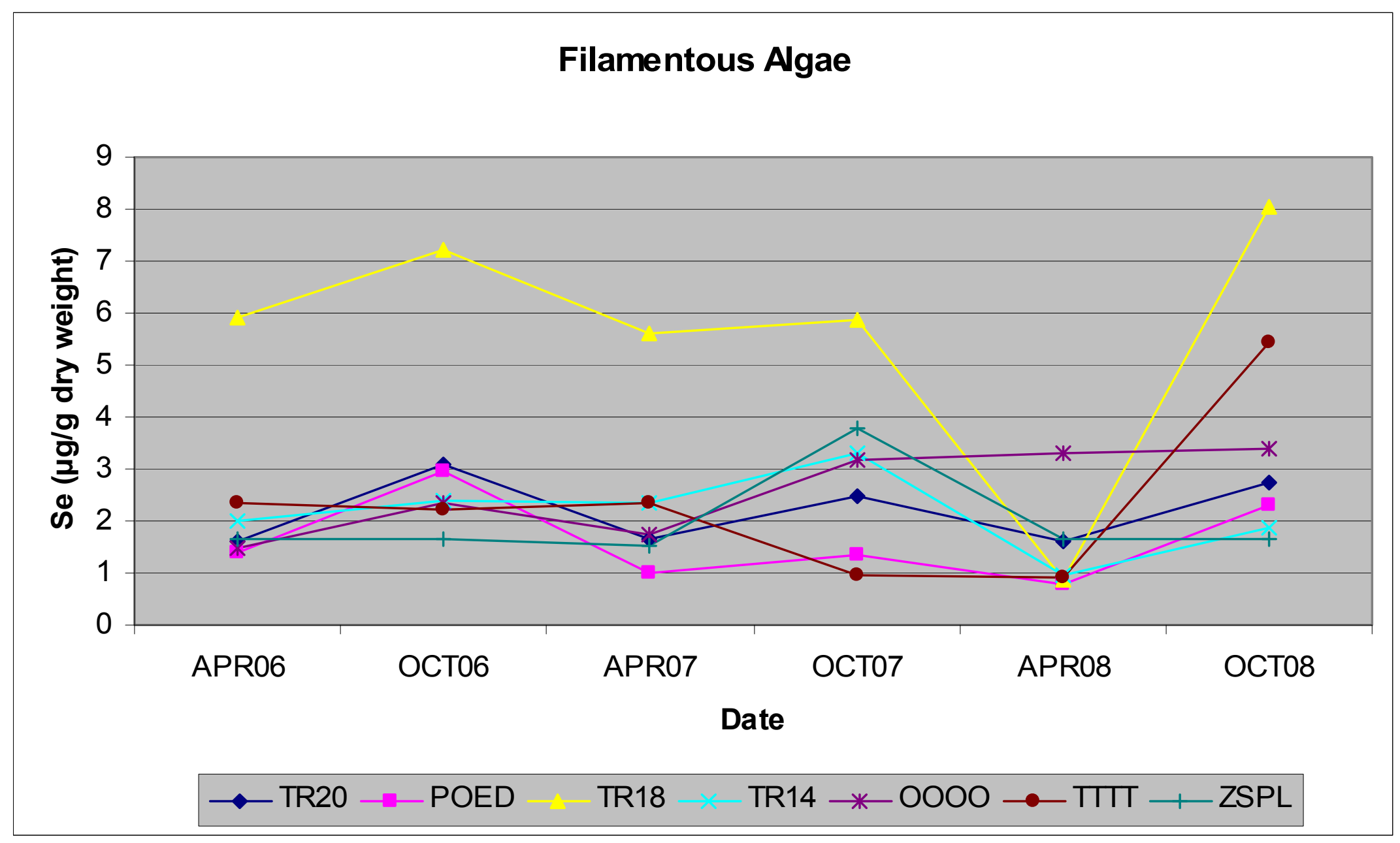

Figure 38. Graph of sampling dates and selenium concentrations in filamentous algae from seven agricultural drains. Codes for drains are given in table 1. 


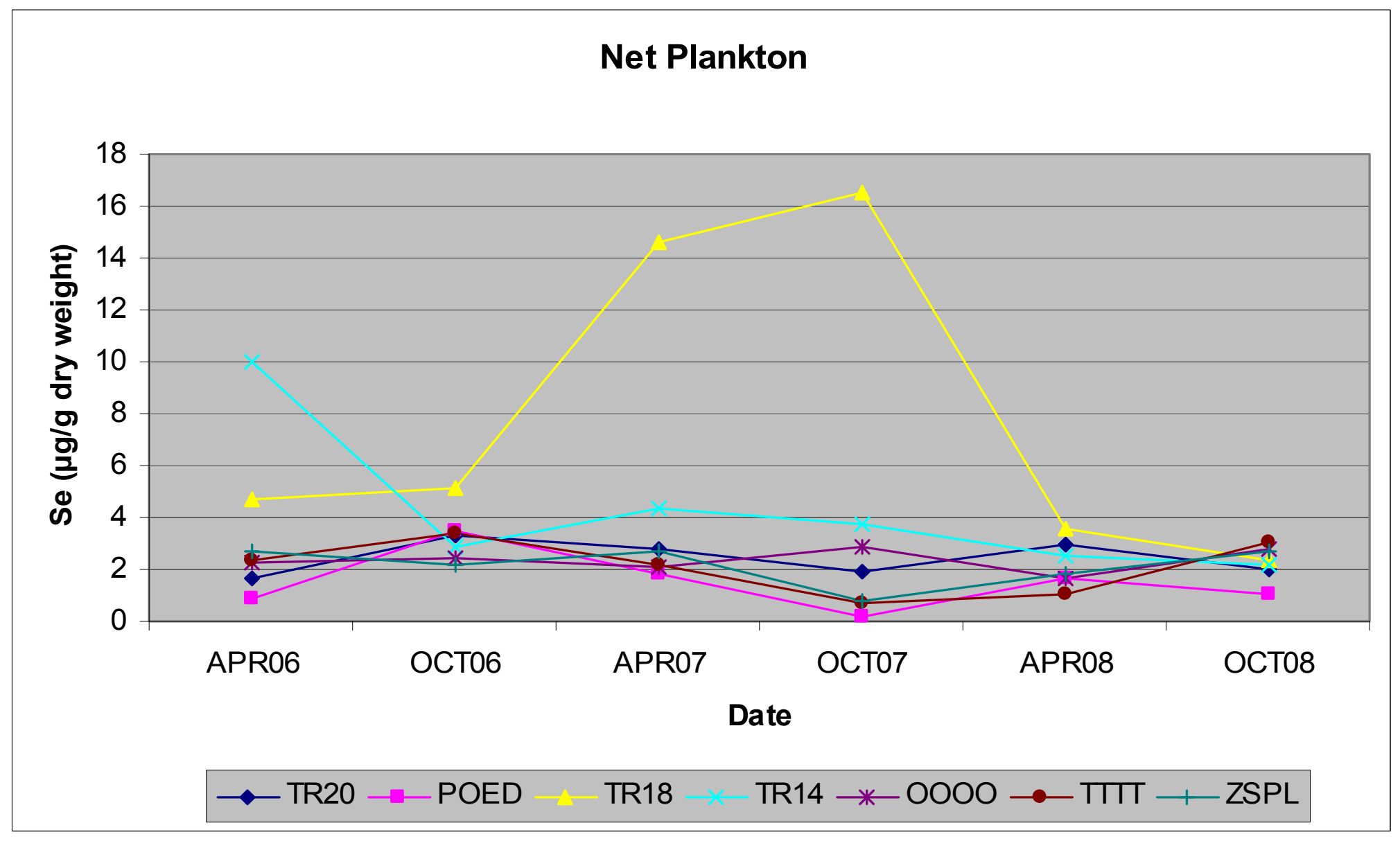

Figure 39. Graph of sampling dates and selenium concentrations in net plankton from seven agricultural drains. Codes for drains are given in table 1. 


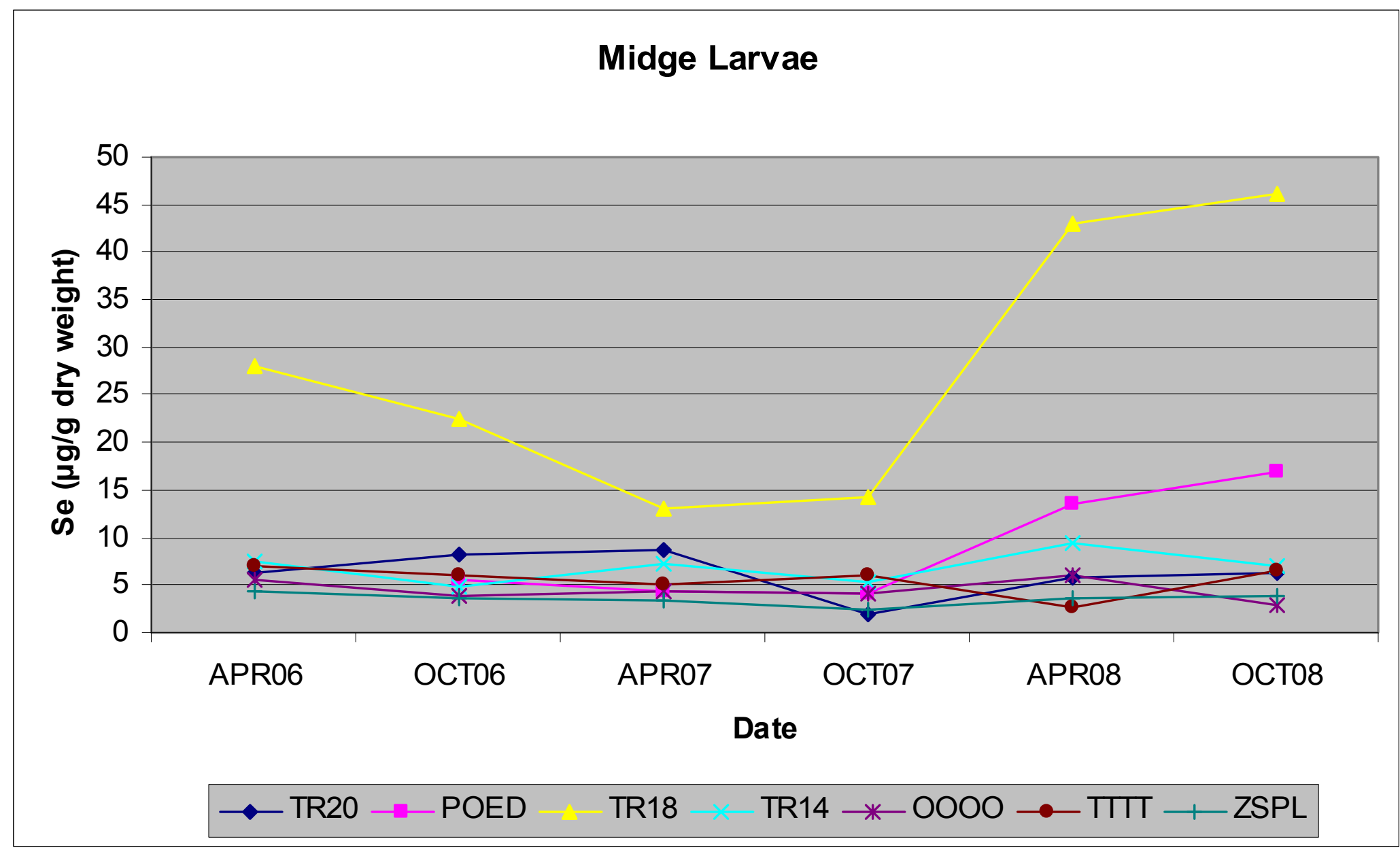

Figure 40. Graph of sampling dates and selenium concentrations in midge larvae from seven agricultural drains. Codes for drains are given in table 1. 


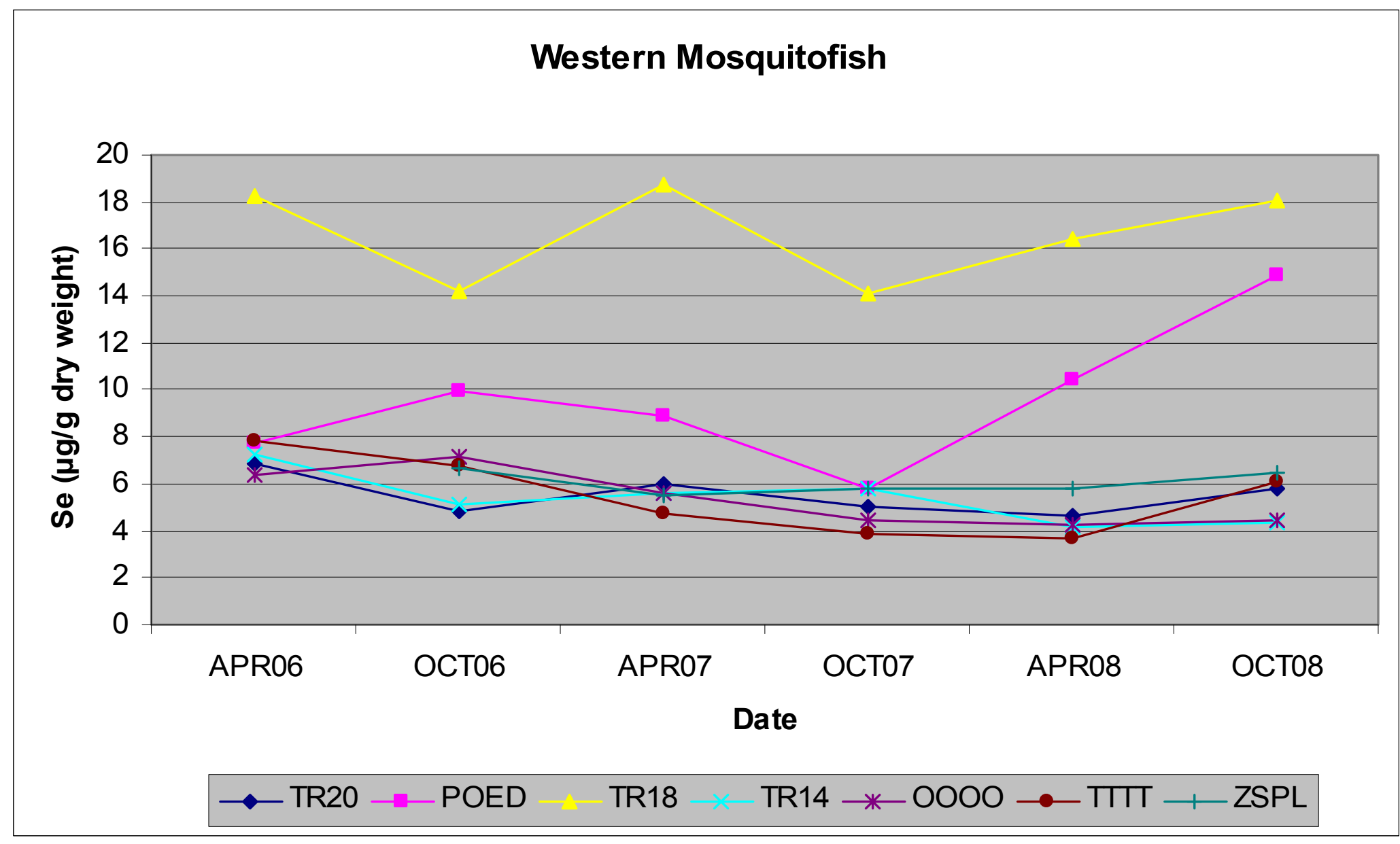

Figure 41. Graph of sampling dates and selenium concentrations in western mosquitofish from seven agricultural drains. Codes for drains are given in table 1. 


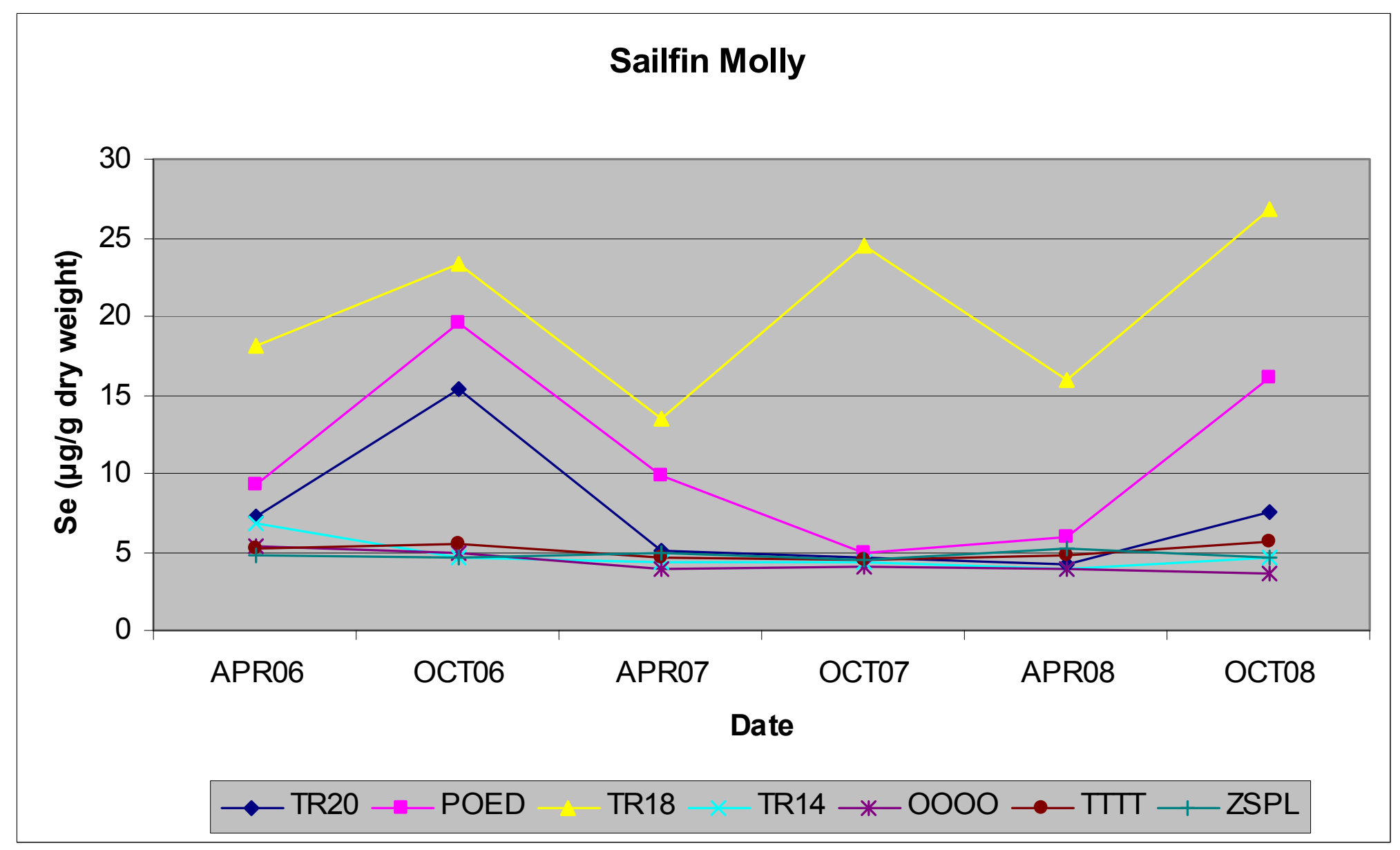

Figure 42. Graph of sampling dates and selenium concentrations in sailfin molly from seven agricultural drains. Codes for drains are given in table 1. 


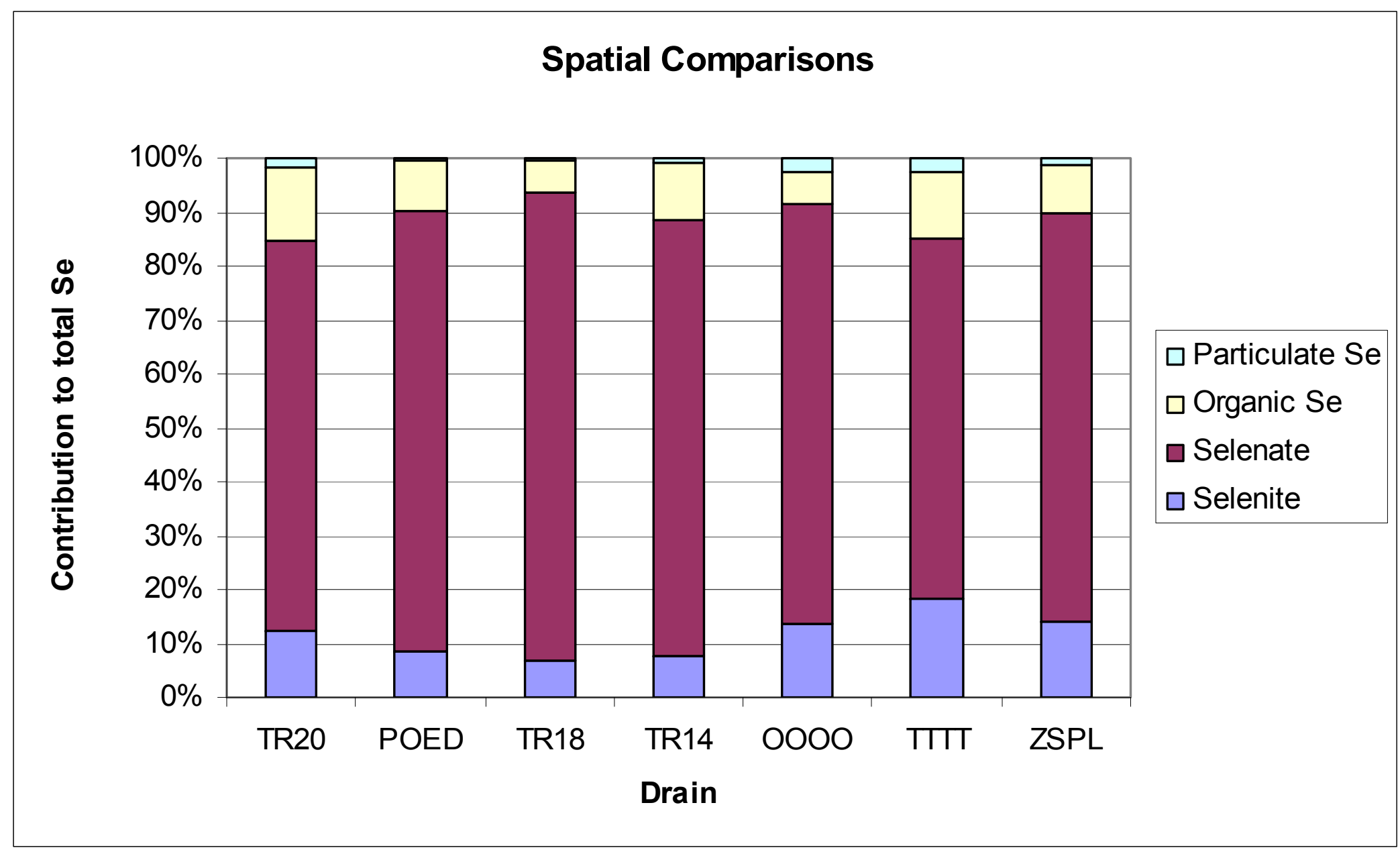

Figure 43. Graph of particulate and dissolved selenium fractions in unfiltered water samples from seven intensively monitored agricultural drains. Dissolved fractions consisted of selenate, selenite, and organic selenium. Codes for drains are given in table 1. 


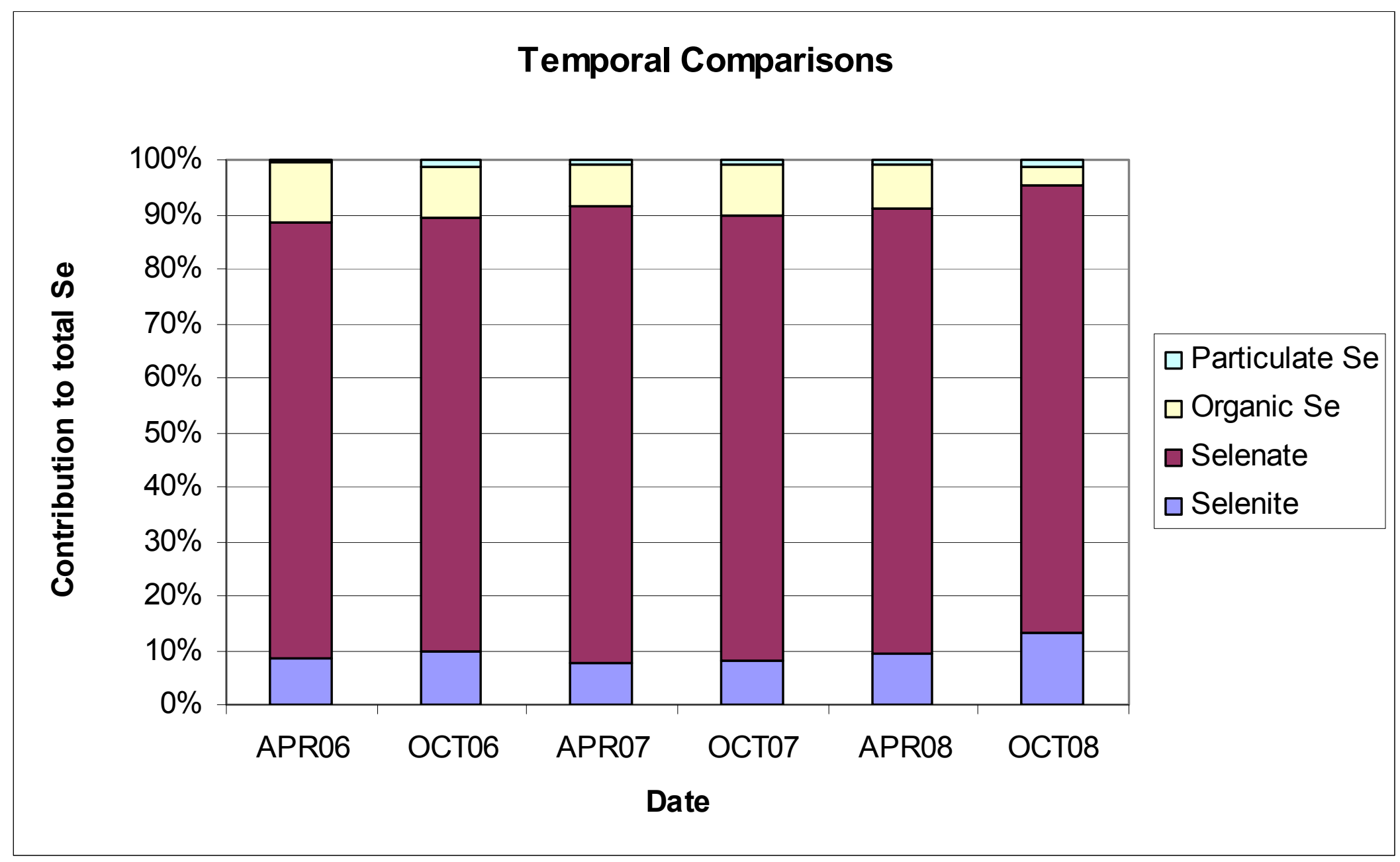

Figure 44. Graph of particulate and dissolved selenium fractions in unfiltered water samples collected on six sampling dates. Dissolved fractions consisted of selenate, selenite, and organic selenium. 


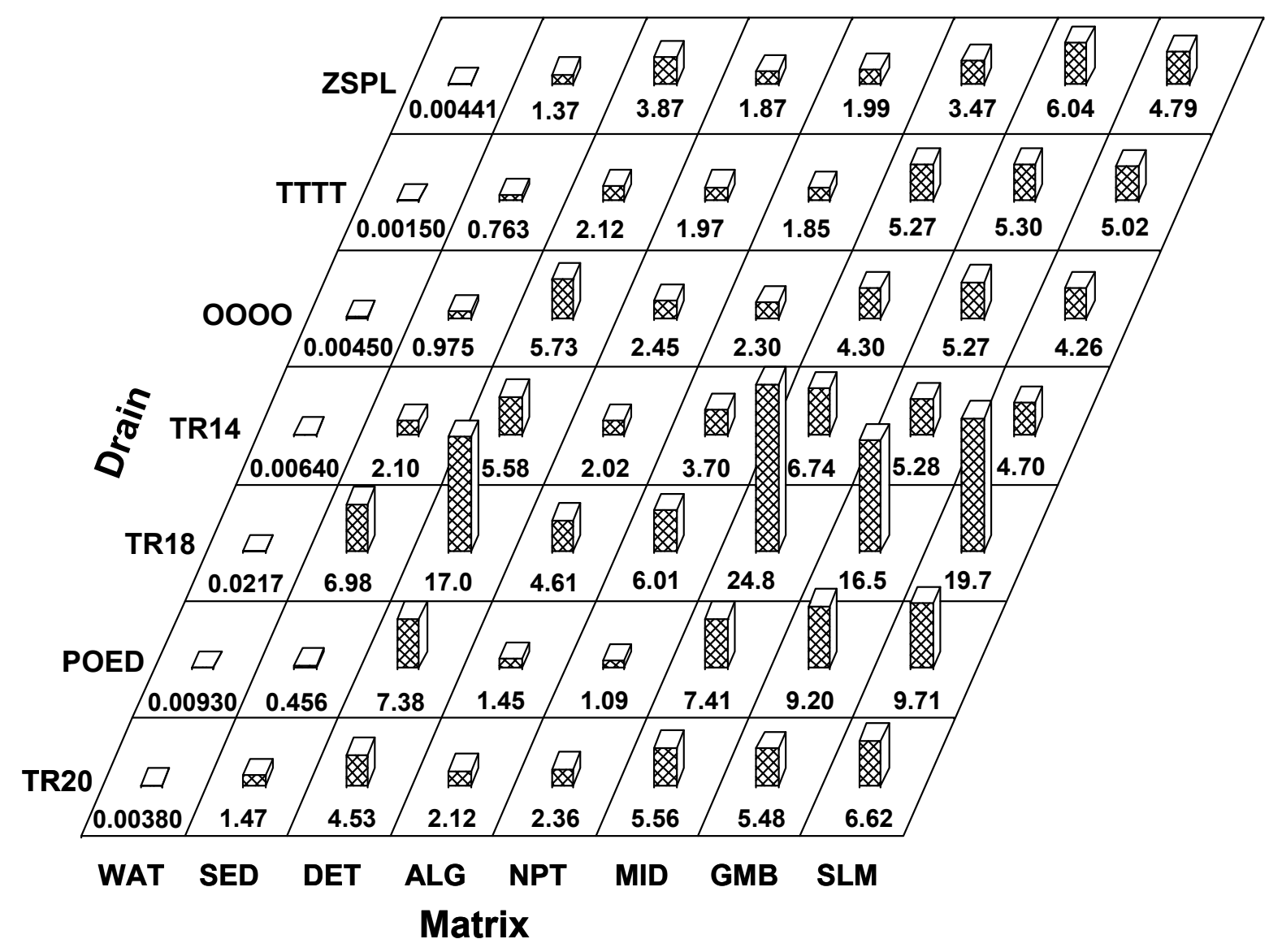

Figure 45. Matrix of selenium concentrations $(\mu \mathrm{g} / \mathrm{mL}$ or $\mu \mathrm{g} / \mathrm{g}$ dry weight; all values roughly equivalent to "parts per million") in filtered water (TWAT), sediment (SED), particulate organic detritus (DET), filamentous algae (ALG), net plankton (NPT), midge larvae (MID), western mosquitofish (GMB), and sailfin molly (SLM). Values are unweighted geometric grand means for samples collected from seven intensively monitored drains on six sampling dates. Codes for drains are given in table 1. 


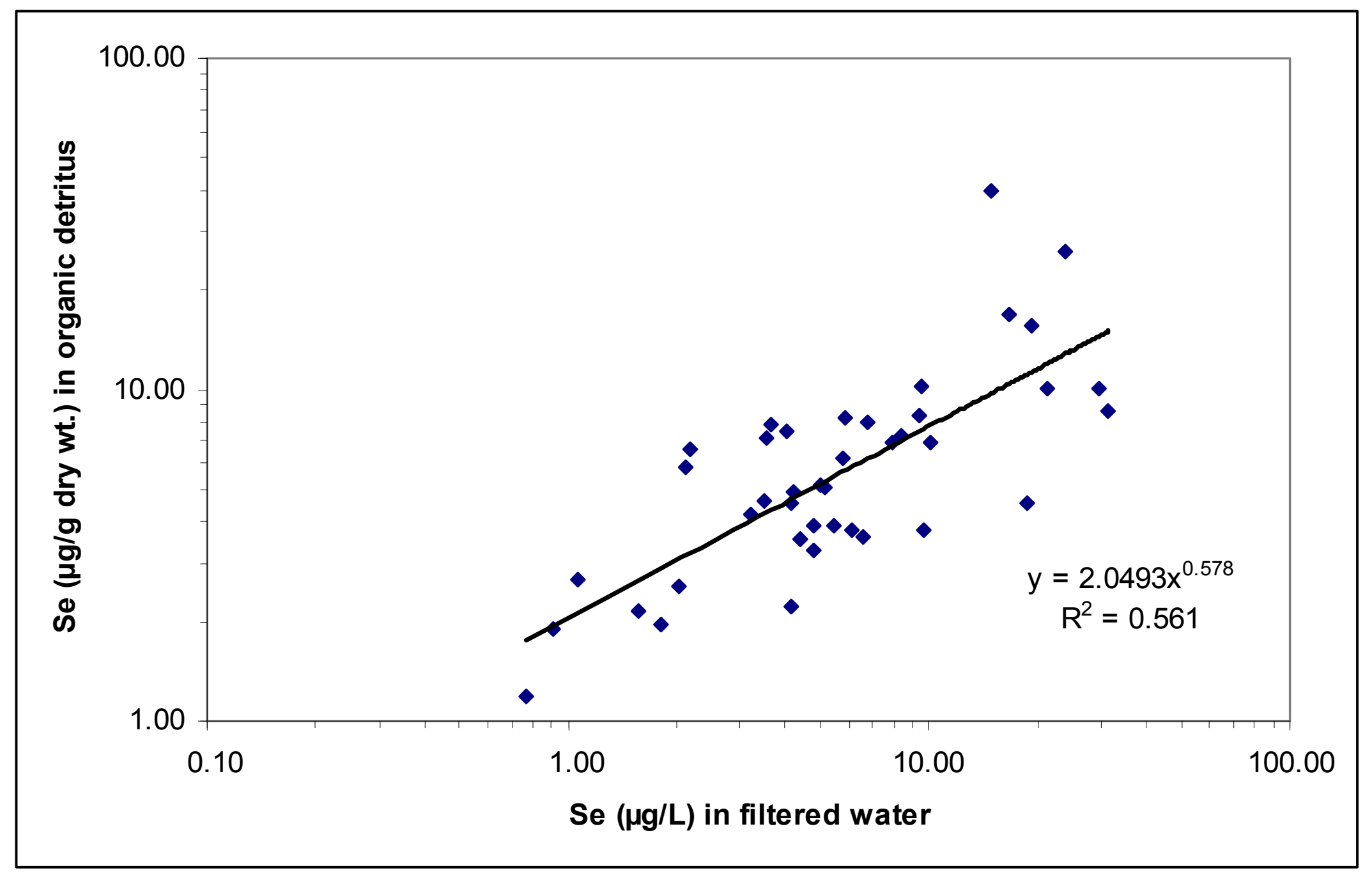

Figure 46. Graph of selenium concentrations measured in filtered water samples and in particulate organic detritus. 


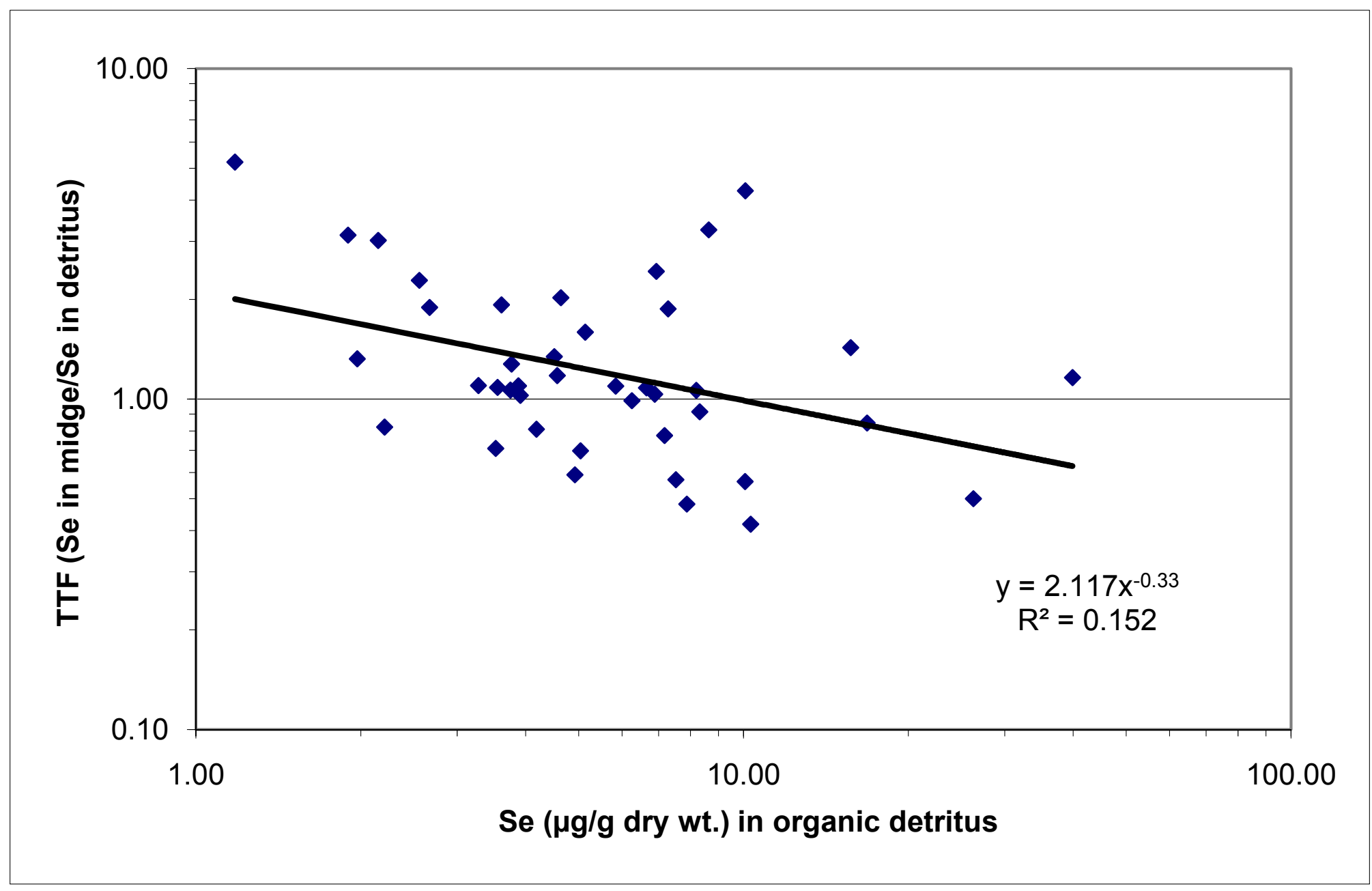

Figure 47. Graph of trophic transfer factors (TTF) for midge larvae and selenium concentrations in particulate organic detritus. 


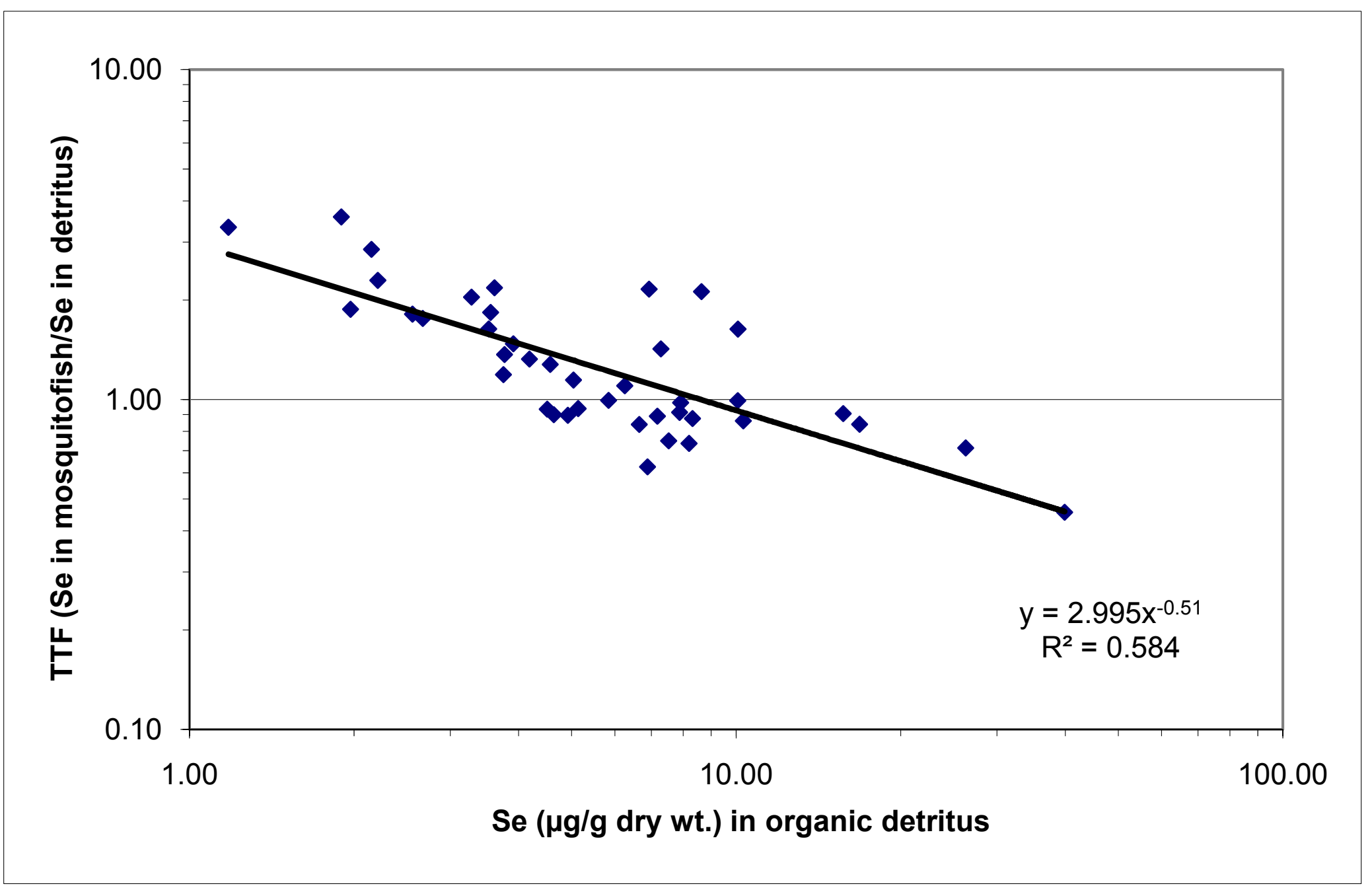

Figure 48. Graph of trophic transfer factors (TTF) for western mosquitofish and selenium concentrations in particulate organic detritus. 


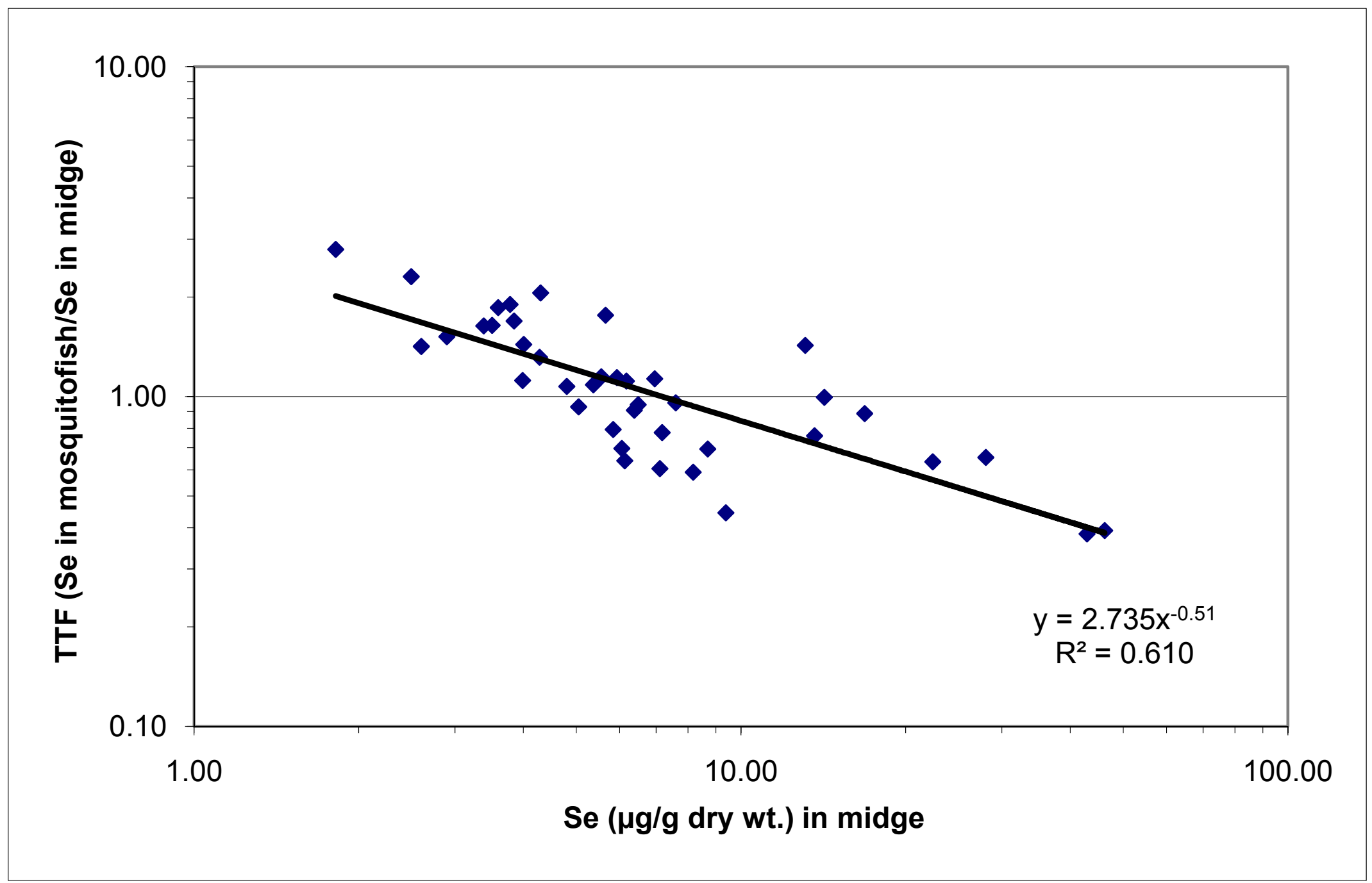

Figure 49. Graph of trophic transfer factors (TTF) for western mosquitofish and selenium concentrations in midge larvae. 


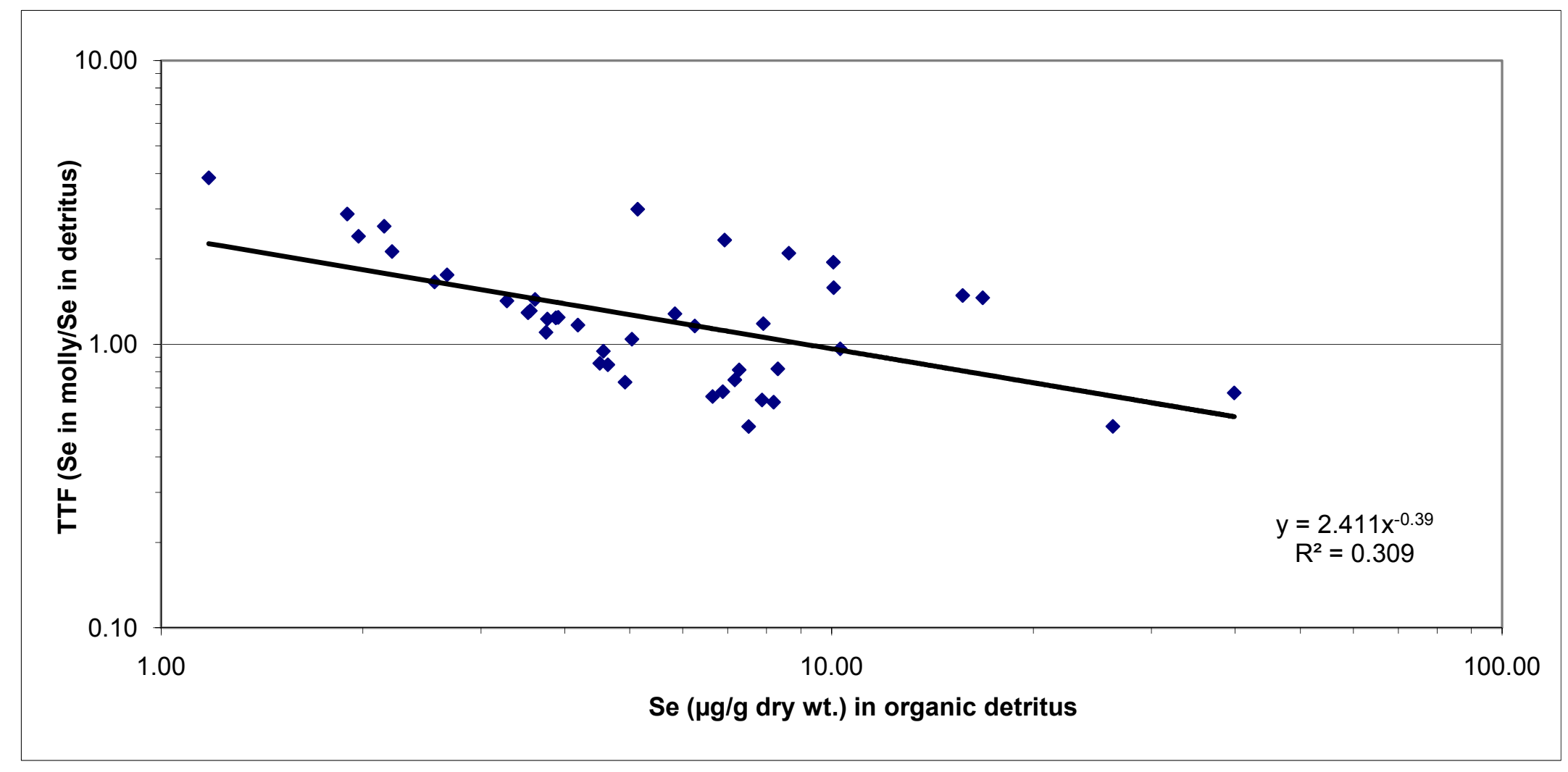

Figure 50. Graph of trophic transfer factors (TTF) for sailfin molly and selenium concentrations in particulate organic detritus. 


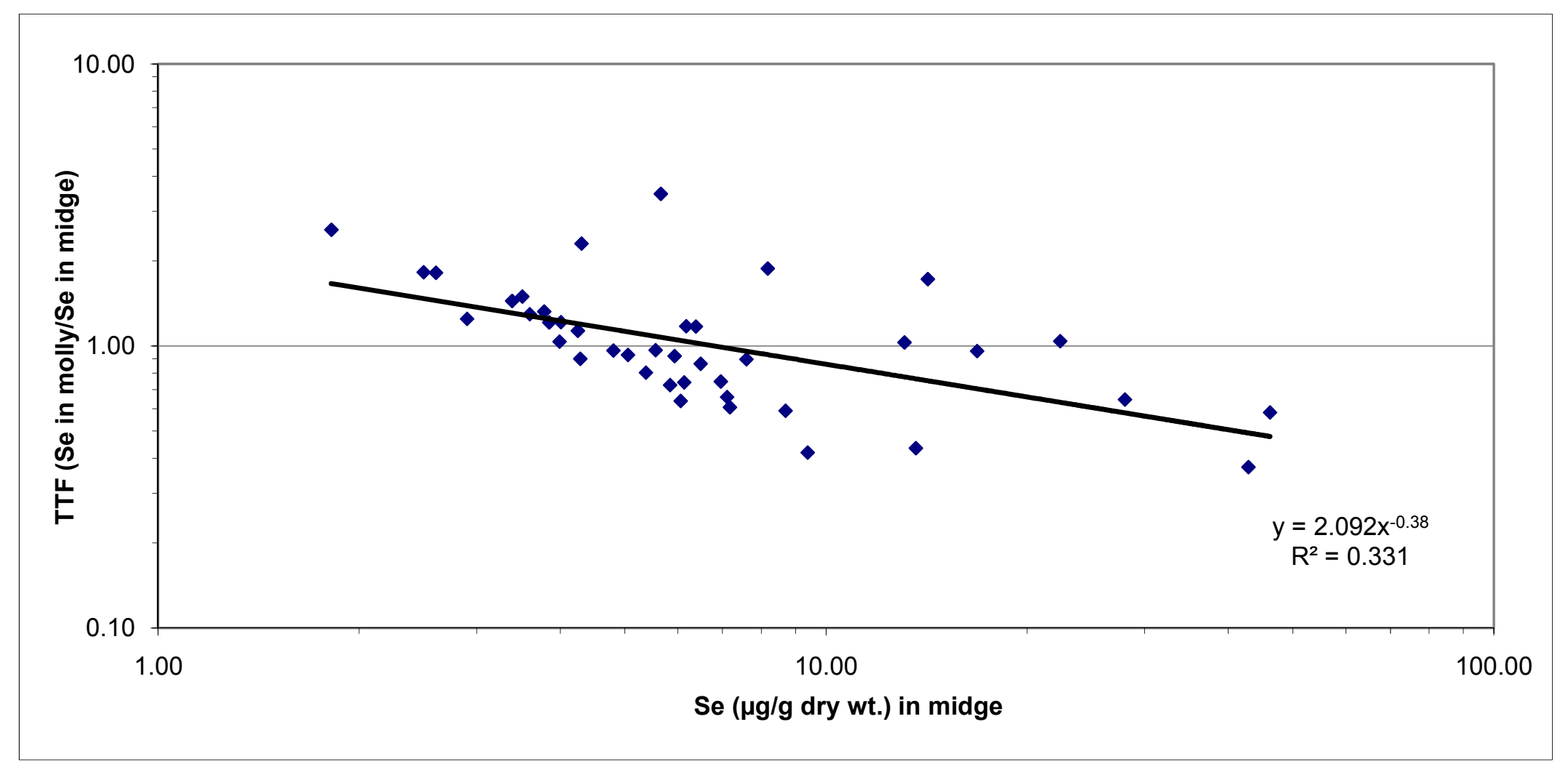

Figure 51. Graph of trophic transfer factors (TTF) for sailfin molly and selenium concentrations in midge larvae. 
Table 1. List of 29 agricultural drains and ponds selected for study as part of the baseline selenium monitoring project.

[ID, identification code; ${ }^{\circ}$, degree; ', minute; $\mathrm{N}$, north latitude; $\mathrm{W}$, west longitude]

\begin{tabular}{|c|c|c|}
\hline Drain or pond & Drain ID & $\begin{array}{l}\text { Geospatial coordinates of } \\
\text { fixed sampling stations }\end{array}$ \\
\hline Trifolium 23 & TR23 & $33^{\circ} 08.843^{\prime} \mathrm{N}, 115^{\circ} 47.626^{\prime} \mathrm{W}$ \\
\hline San Felipe Wash & SFWH & $33^{\circ} 08.380^{\prime} \mathrm{N}, 115^{\circ} 47.411^{\prime} \mathrm{W}$ \\
\hline Trifolium 22 & TR22 & $33^{\circ} 07.707^{\prime} \mathrm{N}, 115^{\circ} 46.860^{\prime} \mathrm{W}$ \\
\hline Former Trifolium $20^{1}$ & FT20 & $33^{\circ} 06.651^{\prime} \mathrm{N}, 115^{\circ} 46.204^{\prime} \mathrm{W}$ \\
\hline Trifolium $20^{2}$ & TR20 & $33^{\circ} 06.519^{\prime} \mathrm{N}, 115^{\circ} 45.927^{\prime} \mathrm{W}$ \\
\hline Trifolium 19 & TR19 & $33^{\circ} 06.281^{\prime} \mathrm{N}, 115^{\circ} 45.606^{\prime} \mathrm{W}$ \\
\hline Poe & POED & $33^{\circ} 06.053^{\prime} \mathrm{N}, 115^{\circ} 45.112^{\prime} \mathrm{W}$ \\
\hline Trifolium 18 & TR18 & $33^{\circ} 05.939^{\prime} \mathrm{N}, 115^{\circ} 44.141^{\prime} \mathrm{W}$ \\
\hline Trifolium Storm & TRST & $33^{\circ} 05.829^{\prime} \mathrm{N}, 115^{\circ} 43.607^{\prime} \mathrm{W}$ \\
\hline Trifolium 1 & TR01 & $33^{\circ} 05.258^{\prime} \mathrm{N}, 115^{\circ} 43.088^{\prime} \mathrm{W}$ \\
\hline Trifolium 14A & TR14 & $33^{\circ} 05.445^{\prime} \mathrm{N}, 115^{\circ} 42.046^{\prime} \mathrm{W}$ \\
\hline Trifolium 13 & TR13 & $33^{\circ} 05.793^{\prime} \mathrm{N}, 115^{\circ} 41.528^{\prime} \mathrm{W}$ \\
\hline Trifolium 12 & TR12 & $33^{\circ} 06.172^{\prime} \mathrm{N}, 115^{\circ} 41.107^{\prime} \mathrm{W}$ \\
\hline Lack \& Lindsey Pond & LKLN & $33^{\circ} 08.845^{\prime} \mathrm{N}, 115^{\circ} 39.080^{\prime} \mathrm{W}$ \\
\hline Vail 5 Pond $^{3}$ & VL05 & $33^{\circ} 10.264^{\prime} \mathrm{N}, 115^{\circ} 37.802^{\prime} \mathrm{W}$ \\
\hline Pumice Pond & PUMC & $33^{\circ} 10.596^{\prime} \mathrm{N}, 115^{\circ} 37.448^{\prime} \mathrm{W}$ \\
\hline $\mathrm{O}$ & OOOO & $33^{\circ} 12.353^{\prime} \mathrm{N}, 115^{\circ} 35.234^{\prime} \mathrm{W}$ \\
\hline $\mathrm{P}$ & РPРP & $33^{\circ} 12.785^{\prime} \mathrm{N}, 115^{\circ} 35.078^{\prime} \mathrm{W}$ \\
\hline $\mathrm{Q}$ & QQQQ & $33^{\circ} 13.398^{\prime} \mathrm{N}, 115^{\circ} 35.087^{\prime} \mathrm{W}$ \\
\hline $\mathrm{R}$ & RRRR & $33^{\circ} 13.645^{\prime} \mathrm{N}, 115^{\circ} 35.180^{\prime} \mathrm{W}$ \\
\hline S & SSSS & $33^{\circ} 14.079^{\prime} \mathrm{N}, 115^{\circ} 35.205^{\prime} \mathrm{W}$ \\
\hline $\mathrm{T}$ & TTTT & $33^{\circ} 14.511^{\prime} \mathrm{N}, 115^{\circ} 35.056^{\prime} \mathrm{W}$ \\
\hline $\mathrm{U}$ & UUUU & $33^{\circ} 14.949^{\prime} \mathrm{N}, 115^{\circ} 35.418^{\prime} \mathrm{W}$ \\
\hline $\mathrm{W}$ & WWWW & $33^{\circ} 15.829^{\prime} \mathrm{N}, 115^{\circ} 35.607^{\prime} \mathrm{W}$ \\
\hline Z Spill & ZSPL & $33^{\circ} 16.688^{\prime} \mathrm{N}, 115^{\circ} 36.135^{\prime} \mathrm{W}$ \\
\hline Niland 1 & NLD1 & $33^{\circ} 17.073^{\prime} \mathrm{N}, 115^{\circ} 36.249^{\prime} \mathrm{W}$ \\
\hline Niland 2 & NLD2 & $33^{\circ} 17.563^{\prime} \mathrm{N}, 115^{\circ} 36.530^{\prime} \mathrm{W}$ \\
\hline Niland 3 & NLD3 & $33^{\circ} 17.972^{\prime} \mathrm{N}, 115^{\circ} 36.713^{\prime} \mathrm{W}$ \\
\hline Niland 4 & NLD4 & $33^{\circ} 18.428^{\prime} \mathrm{N}, 115^{\circ} 37.098^{\prime} \mathrm{W}$ \\
\hline
\end{tabular}

${ }^{1}$ Former Trifolium 20 Drain is occasionally referred to as "Trifolium 20 Drain."

${ }^{2}$ Trifolium 20 Drain is occasionally referred to as "Trifolium 20A Drain."

${ }^{3}$ Vail 5 Pond also is referred to as "McKendry Pond." 
Table 2. Pearson product-moment correlation coefficients and $P$ values for selected water quality variables measured at 29 agricultural drains and ponds on a quarterly basis from July 2005 through April 2009.

[Sample size is 463. Variable: Temp, temperature; DO, dissolved oxygen; TSS, total suspended solids; selenium, total selenium; $P$, level of significance; *, significant according to an adjusted Bonferroni $P=$ 0.0024 for 21 simultaneous comparisons. $<$, less than]

\begin{tabular}{|c|c|c|c|c|c|c|c|}
\hline Variable & Temp & DO & $\mathrm{pH}$ & Salinity & Turbidity & TSS & Selenium \\
\hline Temp & 1.00 & $\begin{array}{r}-0.36 \\
P<0.0001^{*}\end{array}$ & $\begin{array}{r}0.02 \\
P=0.6783\end{array}$ & $\begin{array}{r}0.09 \\
P=0.0529\end{array}$ & $\begin{array}{r}0.03 \\
P=0.4561\end{array}$ & $\begin{array}{r}0.07 \\
P=0.1546\end{array}$ & $\begin{array}{r}0.09 \\
P=0.0497\end{array}$ \\
\hline DO & & 1.00 & $\begin{array}{r}0.18 \\
P<0.0001^{*}\end{array}$ & $\begin{array}{r}-0.18 \\
P<0.0001^{*}\end{array}$ & $\begin{array}{r}0.05 \\
P=0.2503\end{array}$ & $\begin{array}{r}-0.06 \\
P=0.1861\end{array}$ & $\begin{array}{r}-0.01 \\
P=0.8871\end{array}$ \\
\hline $\mathrm{pH}$ & & & 1.00 & $\begin{array}{r}-0.12 \\
P=0.0075\end{array}$ & $\begin{array}{r}0.10 \\
P=0.0297\end{array}$ & $\begin{array}{r}0.17 \\
P=0.0002^{*}\end{array}$ & $\begin{array}{r}-0.22 \\
P<0.0001^{*}\end{array}$ \\
\hline Salinity & & & & 1.00 & $\begin{array}{r}-0.20 \\
P<0.0001^{*}\end{array}$ & $\begin{array}{r}-0.31 \\
P<0.0001^{*}\end{array}$ & $\begin{array}{r}0.51 \\
P<0.0001^{*}\end{array}$ \\
\hline Turbidity & & & & & 1.00 & $\begin{array}{r}0.35 \\
P<0.0001^{*}\end{array}$ & $\begin{array}{r}-0.13 \\
P=0.0071\end{array}$ \\
\hline TSS & & & & & & 1.00 & $\begin{array}{r}-0.15 \\
P=0.0016^{*}\end{array}$ \\
\hline Selenium & & & & & & & 1.00 \\
\hline
\end{tabular}


Table 3. Pearson product-moment correlation coefficients and $P$ values for selected sedimentquality variables measured either annually (during April 2006-09) or semi-annually (during April and October 2006-08) from as many as 29 agricultural drains and ponds.

[Sample size is 137. Variable: Temp, temperature; ORP, oxidation-reduction potential; TOC, total organic carbon; Schoklitsch $\boldsymbol{s}$, Schoklitsch sediment factor; selenium, total selenium; $P$, level of significance; *, significant according to an adjusted Bonferroni $P=0.0024$ for 21 simultaneous comparisons. $<$, less than]

\begin{tabular}{|c|c|c|c|c|c|c|}
\hline Variable & Temp & ORP & $\mathrm{pH}$ & TOC & Schoklitsch s & Selenium \\
\hline Temp & 1.00 & $\begin{array}{r}-0.05 \\
P=0.5384\end{array}$ & $\begin{array}{r}-0.08 \\
P=0.3458\end{array}$ & $\begin{array}{r}-0.02 \\
P=0.8299\end{array}$ & $\begin{array}{r}0.01 \\
P=0.8806\end{array}$ & $\begin{array}{r}-0.01 \\
P=0.8818\end{array}$ \\
\hline ORP & & 1.00 & $\begin{array}{r}0.33 \\
P=0.0001^{*}\end{array}$ & $\begin{array}{r}-0.43 \\
P<0.0001^{*}\end{array}$ & $\begin{array}{r}0.15 \\
P=0.0796\end{array}$ & $\begin{array}{r}-0.64 \\
P<0.0001^{*}\end{array}$ \\
\hline $\mathrm{pH}$ & & & 1.00 & $\begin{array}{r}-0.02 \\
P=0.8371\end{array}$ & $\begin{array}{r}0.32 \\
P=0.0002^{*}\end{array}$ & $\begin{array}{r}-0.17 \\
P=0.0435\end{array}$ \\
\hline TOC & & & & 1.00 & $\begin{array}{r}0.16 \\
P=0.0582\end{array}$ & $\begin{array}{r}0.55 \\
P<0.0001^{*}\end{array}$ \\
\hline Schoklitsch $s$ & & & & & 1.00 & $\begin{array}{r}-0.03 \\
P=0.7492\end{array}$ \\
\hline Selenium & & & & & & 1.00 \\
\hline
\end{tabular}


Table 4. Cumulative numbers of nine fish species captured with baited minnow traps from 29 agricultural drains and ponds (values are not adjusted for variable fishing effort), and number of sampling trips.

[Fish were not sampled in July 2007; see text section "Fish Species Composition and Abundance." Names of drains and ponds are shown in table 1. Number of sampling trips $(\mathrm{N})$ during which as many as 10 baited minnow traps were fished for approximately 1 hour. Fish species: GMB, western mosquitofish; SLM, sailfin molly; RT, redbelly tilapia; MT, hybrid Mozambique tilapia; RSH, red shiner; DP, desert pupfish; BG, bluegill; $\mathrm{CP}$, common carp; and GF, goldfish]

\begin{tabular}{|c|c|c|c|c|c|c|c|c|c|c|c|}
\hline \multirow{2}{*}{$\begin{array}{c}\text { Drain or } \\
\text { pond }\end{array}$} & \multirow{2}{*}{$\mathbf{N}$} & \multicolumn{10}{|c|}{ Fish species, in number of fish caught } \\
\hline & & GMB & SLM & RT & MT & RSH & $\mathrm{DP}$ & BG & $\mathrm{CP}$ & GF & Total \\
\hline TR23 & 15 & 330 & 28 & 2 & 18 & 1,637 & 2 & 1 & 0 & 10 & $\overline{2,028}$ \\
\hline SFWH & 15 & 214 & 238 & 3 & 7 & 32 & 1 & 4 & 0 & 0 & 499 \\
\hline TR22 & 15 & 102 & 39 & 0 & 9 & 108 & 16 & 0 & 0 & 0 & 274 \\
\hline FT20 & 14 & 461 & 61 & 2 & 53 & 9 & 48 & 0 & 0 & 0 & 634 \\
\hline TR20 & 15 & 1,455 & 265 & 3 & 76 & 15 & 4 & 0 & 0 & 0 & 1,818 \\
\hline TR19 & 15 & 9,617 & 2,001 & 0 & 0 & 0 & 0 & 0 & 0 & 0 & 11,618 \\
\hline POED & 15 & 1,066 & 716 & 0 & 185 & 222 & 16 & 1 & 0 & 0 & 2,206 \\
\hline TR18 & 15 & 1,414 & 2,972 & 13 & 61 & 0 & 116 & 0 & 0 & 0 & 4,576 \\
\hline TRST & 8 & 90 & 80 & 0 & 0 & 0 & 357 & 0 & 0 & 0 & 527 \\
\hline TR01 & 14 & 111 & 17 & 0 & 0 & 124 & 0 & 0 & 0 & 1 & 253 \\
\hline TR14 & 15 & 307 & 451 & 0 & 9 & 0 & 163 & 0 & 0 & 0 & 930 \\
\hline TR13 & 15 & 671 & 108 & 1 & 16 & 152 & 26 & 0 & 0 & 0 & 974 \\
\hline TR12 & 12 & 277 & 20 & 1 & 0 & 19 & 1 & 1 & 0 & 0 & 319 \\
\hline VL05 & 15 & 26 & 0 & 0 & 2 & 33 & 1 & 5 & 0 & 0 & 67 \\
\hline LKLN & 14 & 11 & 559 & 1 & 16 & 0 & 7 & 0 & 0 & 0 & 594 \\
\hline PUMC & 15 & 73 & 323 & 0 & 5 & 1 & 2 & 0 & 0 & 0 & 404 \\
\hline 0000 & 15 & 1,458 & 170 & 2 & 18 & 8 & 7 & 0 & 1 & 0 & 1,664 \\
\hline PPPP & 15 & 234 & 3 & 0 & 8 & 361 & 0 & 0 & 0 & 0 & 606 \\
\hline $\mathrm{QQQQ}$ & 15 & 5 & 4 & 0 & 0 & 60 & 1 & 4 & 0 & 0 & 74 \\
\hline RRRR & 14 & 998 & 39 & 0 & 14 & 1 & 0 & 6 & 0 & 0 & 1,058 \\
\hline SSSS & 15 & 93 & 1 & 0 & 0 & 0 & 0 & 0 & 0 & 0 & 94 \\
\hline TTTT & 14 & 4,284 & 557 & 0 & 1 & 48 & 23 & 1 & 10 & 0 & 4,924 \\
\hline UUUU & 14 & 1,062 & 116 & 0 & 6 & 1,404 & 17 & 91 & 0 & 0 & 2,696 \\
\hline WWWW & 14 & 62 & 19 & 0 & 2 & 7 & 1 & 0 & 0 & 0 & 91 \\
\hline ZSPL & 15 & 8 & 122 & 1 & 0 & 9 & 5 & 0 & 0 & 0 & 145 \\
\hline NLD1 & 15 & 3,218 & 309 & 0 & 0 & 22 & 1 & 4 & 0 & 0 & 3,554 \\
\hline NLD2 & 15 & 497 & 21 & 0 & 0 & 35 & 0 & 0 & 1 & 1 & 555 \\
\hline NLD3 & 15 & 791 & 31 & 0 & 0 & 18 & 1 & 0 & 0 & 0 & 841 \\
\hline NLD4 & 15 & 5 & 1 & 0 & 0 & 9 & 0 & 2 & 0 & 0 & 17 \\
\hline Total & 418 & 28,940 & 9,271 & 29 & 506 & 4,334 & 816 & 120 & 12 & 12 & 44,040 \\
\hline
\end{tabular}


Table 5. Catch-per-unit-effort (mean numbers of fish per 10 minnow traps fished for 1 hour) for nine fish species captured at roughly quarterly intervals between July 2005 and April 2009.

[Names of drains and ponds are shown in table 1. Fish species: GMB, western mosquitofish; SLM, sailfin molly; RT, redbelly tilapia; MT, hybrid Mozambique tilapia; RSH, red shiner; DP, desert pupfish; BG, bluegill; $\mathrm{CP}$, common carp; and GF, goldfish]

\begin{tabular}{|c|c|c|c|c|c|c|c|c|c|c|}
\hline \multirow{2}{*}{$\begin{array}{l}\text { Drain or } \\
\text { pond }\end{array}$} & \multicolumn{10}{|c|}{ Fish species, in number of fish caught } \\
\hline & GMB & SLM & RT & MT & RSH & $\mathrm{DP}$ & BG & $\mathrm{CP}$ & GF & Total \\
\hline TR23 & 22.0 & 1.9 & 0.1 & 1.2 & 109.1 & 0.1 & 0.1 & 0.0 & 0.7 & 135.2 \\
\hline SFWH & 14.3 & 15.9 & 0.2 & 0.5 & 2.1 & 0.1 & 0.1 & 0.0 & 0.0 & 33.3 \\
\hline TR22 & 6.8 & 2.6 & 0.0 & 0.6 & 7.2 & 1.1 & 0.0 & 0.0 & 0.0 & 18.3 \\
\hline FT20 & 32.9 & 4.4 & 0.1 & 3.8 & 0.6 & 3.4 & 0.0 & 0.0 & 0.0 & 45.3 \\
\hline TR20 & 97.0 & 17.7 & 0.2 & 5.1 & 1.0 & 0.3 & 0.0 & 0.0 & 0.0 & 121.2 \\
\hline TR19 & 641.1 & 133.4 & 0.0 & 0.0 & 0.0 & 0.0 & 0.0 & 0.0 & 0.0 & 774.5 \\
\hline POED & 71.1 & 47.7 & 0.0 & 12.3 & 14.8 & 1.1 & 0.1 & 0.0 & 0.0 & 147.1 \\
\hline TR18 & 94.3 & 198.1 & 0.9 & 4.1 & 0.0 & 7.7 & 0.0 & 0.0 & 0.0 & 305.1 \\
\hline TRST & 11.3 & 10.0 & 0.0 & 0.0 & 0.0 & 44.6 & 0.0 & 0.0 & 0.0 & 65.9 \\
\hline TR01 & 9.0 & 1.4 & 0.0 & 0.0 & 10.0 & 0.0 & 0.0 & 0.0 & 0.1 & 20.5 \\
\hline TR14 & 20.5 & 30.1 & 0.0 & 0.6 & 0.0 & 10.9 & 0.0 & 0.0 & 0.0 & 62.0 \\
\hline TR13 & 44.7 & 7.2 & 0.1 & 1.1 & 10.1 & 1.7 & 0.0 & 0.0 & 0.0 & 64.9 \\
\hline TR12 & 23.1 & 1.7 & 0.1 & 0.0 & 1.6 & 0.1 & 0.1 & 0.0 & 0.0 & 26.6 \\
\hline LKLN & 1.6 & 60.1 & 0.1 & 2.3 & 0.0 & 0.5 & 0.0 & 0.0 & 0.0 & 65.0 \\
\hline VL05 & 1.7 & 0.0 & 0.0 & 0.3 & 4.4 & 0.1 & 0.7 & 0.0 & 0.0 & 7.2 \\
\hline PUMC & 9.7 & 43.1 & 0.0 & 0.7 & 0.1 & 0.1 & 0.0 & 0.0 & 0.0 & 53.9 \\
\hline OOOO & 97.2 & 11.3 & 0.1 & 1.2 & 0.5 & 0.5 & 0.0 & 0.1 & 0.0 & 110.9 \\
\hline PPPP & 15.6 & 0.2 & 0.0 & 0.5 & 24.1 & 0.0 & 0.0 & 0.0 & 0.0 & 40.4 \\
\hline QQQQ & 0.3 & 0.3 & 0.0 & 0.0 & 4.0 & 0.1 & 0.3 & 0.0 & 0.0 & 4.9 \\
\hline RRRR & 109.4 & 4.1 & 0.0 & 1.0 & 0.1 & 0.0 & 0.4 & 0.0 & 0.0 & 114.9 \\
\hline SSSS & 6.2 & 0.1 & 0.0 & 0.0 & 0.0 & 0.0 & 0.0 & 0.0 & 0.0 & 6.3 \\
\hline TTTT & 306.0 & 39.8 & 0.0 & 0.1 & 3.4 & 1.6 & 0.1 & 0.7 & 0.0 & 351.7 \\
\hline UUUU & 75.9 & 8.3 & 0.0 & 0.4 & 100.3 & 1.2 & 6.5 & 0.0 & 0.0 & 192.6 \\
\hline WWW & 4.4 & 1.4 & 0.0 & 0.1 & 0.5 & 0.1 & 0.0 & 0.0 & 0.0 & 6.5 \\
\hline ZSPL & 0.5 & 8.1 & 0.1 & 0.0 & 0.6 & 0.3 & 0.0 & 0.0 & 0.0 & 9.7 \\
\hline NLD1 & 214.5 & 20.6 & 0.0 & 0.0 & 1.5 & 0.1 & 0.3 & 0.0 & 0.0 & 236.9 \\
\hline NLD2 & 33.1 & 1.4 & 0.0 & 0.0 & 2.3 & 0.0 & 0.0 & 0.1 & 0.1 & 37.0 \\
\hline NLD3 & 52.7 & 2.1 & 0.0 & 0.0 & 1.2 & 0.1 & 0.0 & 0.0 & 0.0 & 56.1 \\
\hline NLD4 & 0.3 & 0.1 & 0.0 & 0.0 & 0.6 & 0.0 & 0.1 & 0.0 & 0.0 & 1.1 \\
\hline Total & $2,017.2$ & 672.8 & 2.0 & 35.8 & 300.2 & 75.7 & 8.6 & 0.8 & 0.8 & $3,115.0$ \\
\hline
\end{tabular}


Table 6. Spearman rank correlation coefficients and $P$ values between abundances (catch-per-uniteffort) of various fish species caught with minnow traps at 29 agricultural drains and ponds over a 4-year time period.

[Sample size is 418. Fish species: GMB, western mosquitofish; SLM, sailfin molly; RT, redbelly tilapia; MT, hybrid Mozambique tilapia; RSH, red shiner; DP, desert pupfish; BG, bluegill; CP, common carp; and GF, goldfish. $\mathrm{P}$, level of significance. *, significant according to an adjusted Bonferroni $\mathrm{P}=0.0014$ for 36 simultaneous comparison. $<$, less than]

\begin{tabular}{|c|c|c|c|c|c|c|c|c|c|}
\hline Taxa & GMB & SLM & RT & MT & RSH & DP & BG & $C P$ & GF \\
\hline GMB & 1.00 & $\begin{array}{r}0.62 \\
P<0.0001^{*}\end{array}$ & $\begin{array}{r}0.18 \\
P=0.0002^{*}\end{array}$ & $\begin{array}{r}0.31 \\
P<0.0001^{*}\end{array}$ & $\begin{array}{r}0.23 \\
P<0.0001^{*}\end{array}$ & $\begin{array}{r}0.29 \\
P<0.0001^{*}\end{array}$ & $\begin{array}{r}-0.04 \\
P=0.4790\end{array}$ & $\begin{array}{r}0.10 \\
P=0.0408\end{array}$ & $\begin{array}{r}0.03 \\
P=0.5702\end{array}$ \\
\hline SLM & & 1.00 & $\begin{array}{r}0.18 \\
P=0.0003^{*}\end{array}$ & $\begin{array}{r}0.35 \\
P<0.0001^{*}\end{array}$ & $\begin{array}{r}0.06 \\
P=0.1901\end{array}$ & $\begin{array}{r}0.39 \\
P<0.0001^{*}\end{array}$ & $\begin{array}{r}-0.05 \\
P=0.3079\end{array}$ & $\begin{array}{r}0.03 \\
P=0.4847\end{array}$ & $\begin{array}{r}-0.02 \\
P=0.6812\end{array}$ \\
\hline RT & & & 1.00 & $\begin{array}{r}0.17 \\
P=0.0004^{*}\end{array}$ & $\begin{array}{r}0.12 \\
P=0.0187\end{array}$ & $\begin{array}{r}<0.01 \\
\mathrm{P}=0.9320\end{array}$ & $P=0.3373$ & $\begin{array}{r}0.15 \\
P=0.0028\end{array}$ & $\begin{array}{r}-0.02 \\
P=0.7562\end{array}$ \\
\hline MT & & & & 1.00 & $\begin{array}{r}0.13 \\
P=0.0083\end{array}$ & $\begin{array}{r}0.28 \\
P<0.0001^{*}\end{array}$ & $\begin{array}{r}0.01 \\
P=0.8578\end{array}$ & $\begin{array}{r}0.05 \\
P=0.3116\end{array}$ & $\begin{array}{r}-0.03 \\
P=0.4924\end{array}$ \\
\hline RSH & & & & & 1.00 & $\begin{array}{r}0.07 \\
P=0.1396\end{array}$ & $\begin{array}{r}0.05 \\
P=0.3556\end{array}$ & $\begin{array}{r}0.03 \\
P=0.5187\end{array}$ & $\begin{array}{r}0.02 \\
P=0.6713\end{array}$ \\
\hline $\mathrm{DP}$ & & & & & & 1.00 & $\begin{array}{r}-0.08 \\
P=0.1221\end{array}$ & $\begin{array}{r}0.06 \\
P=0.2523\end{array}$ & $\begin{array}{r}-0.04 \\
P=0.4795\end{array}$ \\
\hline$B G$ & & & & & & & 1.00 & $\begin{array}{r}-0.02 \\
P=0.6490\end{array}$ & $\begin{array}{r}-0.02 \\
P=0.6490\end{array}$ \\
\hline $\mathrm{CP}$ & & & & & & & & 1.00 & $\begin{array}{r}-0.01 \\
P=0.8829\end{array}$ \\
\hline GF & & & & & & & & & 1.00 \\
\hline
\end{tabular}


Table 7. Spearman rank correlation coefficients and $P$ values between abundance (catch-per-uniteffort) of fish species captured with minnow traps and selected habitat variables.

[Sample size is 418 for all variables except Schoklitsch $\boldsymbol{s}$, where it is 137. Fish species: GMB, western mosquitofish; SLM, sailfin molly; RT, redbelly tilapia; MT, hybrid Mozambique tilapia; RSH, red shiner; DP, desert pupfish; BG, bluegill; CP, common carp; and GF, goldfish; Temp, temperature; ORP, oxidationreduction potential; TOC, total organic carbon; Schoklitsch $s$, Schoklitsch's sediment factor; selenium, total selenium; $\mathrm{P}$, level of significance. *, significant according to an adjusted Bonferroni $\mathrm{P}=0.0063$ for 8 simultaneous comparisons of water quality for each species. $<$, less than]

\begin{tabular}{|c|c|c|c|c|c|c|c|c|c|}
\hline Variable & MB & SLM & RT & MT & RSH & DP & BG & $\mathrm{CP}$ & GF \\
\hline Temp & $\begin{array}{r}0.39 \\
P<0.0001^{*}\end{array}$ & $\begin{array}{r}0.37 \\
P<0.0001^{*}\end{array}$ & $\begin{array}{r}0.09 \\
P=0.0668\end{array}$ & $\begin{array}{r}0.27 \\
P<0.0001^{*}\end{array}$ & $\begin{array}{r}0.15 \\
P=0.0021^{*}\end{array}$ & $\begin{array}{r}0.26 \\
P<0.0001^{*}\end{array}$ & $\begin{array}{r}0.03 \\
P=0.4869\end{array}$ & $\begin{array}{r}0.02 \\
P=0.6969\end{array}$ & $\begin{array}{r}-0.03 \\
P=0.5244\end{array}$ \\
\hline DO & $\begin{array}{r}-0.31 \\
P<0.0001^{*}\end{array}$ & $\begin{array}{r}-0.23 \\
P<0.0001^{*}\end{array}$ & $\begin{array}{r}-0.05 \\
P=0.3130\end{array}$ & $\begin{array}{r}-0.16 \\
P=0.0012^{*}\end{array}$ & $\begin{array}{r}-0.13 \\
P=0.0102\end{array}$ & $\begin{array}{r}-0.10 \\
P=0.0369\end{array}$ & $\begin{array}{r}-0.06 \\
P=0.2107\end{array}$ & $\begin{array}{r}-0.02 \\
P=0.7546\end{array}$ & $\begin{array}{r}-0.01 \\
P=0.9146\end{array}$ \\
\hline $\mathrm{pH}$ & $\begin{array}{r}-0.07 \\
P=0.1785\end{array}$ & $\begin{array}{r}-0.11 \\
P=0.0212\end{array}$ & $\begin{array}{r}-0.01 \\
P=0.8332\end{array}$ & $\begin{array}{r}-0.04 \\
P=0.3905\end{array}$ & $\begin{array}{r}0.01 \\
P=0.8487\end{array}$ & $\begin{array}{r}-0.03 \\
P=0.5202\end{array}$ & $\begin{array}{r}0.03 \\
P=0.5995\end{array}$ & $\begin{array}{r}0.02 \\
P=0.6304\end{array}$ & $\begin{array}{r}-0.07 \\
P=0.1789\end{array}$ \\
\hline Salinity & $\begin{array}{r}0.07 \\
P=0.1575\end{array}$ & $\begin{array}{r}0.27 \\
P<0.0001^{*}\end{array}$ & $\begin{array}{r}0.054 \\
P=0.2678\end{array}$ & $\begin{array}{r}0.12 \\
P=0.0165\end{array}$ & $\begin{array}{r}-0.13 \\
P=0.0089\end{array}$ & $\begin{array}{r}0.19 \\
P<0.0001^{*}\end{array}$ & $\begin{array}{r}-0.08 \\
P=0.0897\end{array}$ & $\begin{array}{r}0.02 \\
P=0.6548\end{array}$ & $\begin{array}{r}-0.05 \\
P=0.2768\end{array}$ \\
\hline Turbidity & $\begin{array}{r}0.09 \\
P=0.0741\end{array}$ & $\begin{array}{r}0.01 \\
P=0.9248\end{array}$ & $\begin{array}{r}0.07 \\
P=0.1814\end{array}$ & $\begin{array}{r}-0.02 \\
P=0.7023\end{array}$ & $\begin{array}{r}0.05 \\
P=0.3208\end{array}$ & $\begin{array}{r}-0.01 \\
P=0.9258\end{array}$ & $\begin{array}{r}0.02 \\
P=0.7546\end{array}$ & $\begin{array}{r}0.05 \\
P=0.3208\end{array}$ & $\begin{array}{r}0.02 \\
P=0.6886\end{array}$ \\
\hline TSS & $\begin{array}{r}-0.02 \\
P=0.6999\end{array}$ & $\begin{array}{r}-0.18 \\
P=0.0002^{*}\end{array}$ & $\begin{array}{r}0.01 \\
P=0.8404\end{array}$ & $\begin{array}{r}-0.20 \\
P<0.0001^{*}\end{array}$ & $\begin{array}{r}0.09 \\
P=0.0567\end{array}$ & $\begin{array}{r}-0.17 \\
P=0.0006^{*}\end{array}$ & $\begin{array}{r}-0.02 \\
P=0.7582\end{array}$ & $\begin{array}{r}0.07 \\
P=0.1459\end{array}$ & $\begin{array}{r}-0.05 \\
P=0.2753\end{array}$ \\
\hline $\begin{array}{c}\text { Schoklitsch } \\
\boldsymbol{s}\end{array}$ & $\begin{array}{r}0.05 \\
P=0.5587\end{array}$ & $\begin{array}{r}0.19 \\
P=0.0339\end{array}$ & $\begin{array}{r}0.02 \\
P=0.7990\end{array}$ & $\begin{array}{r}0.11 \\
P=0.2167\end{array}$ & $\begin{array}{r}-0.18 \\
P=0.0459\end{array}$ & $\begin{array}{r}0.07 \\
P=0.4661\end{array}$ & $\begin{array}{r}-0.01 \\
P=0.9100\end{array}$ & $\begin{array}{r}-0.05 \\
P=0.5824\end{array}$ & $\begin{array}{r}0.06 \\
P=0.5110\end{array}$ \\
\hline Selenium & $\begin{array}{r}0.01 \\
P=0.8383\end{array}$ & $\begin{array}{r}0.17 \\
P=0.0007^{*}\end{array}$ & $\begin{array}{r}0.17 \\
P=0.0175\end{array}$ & $\begin{array}{r}0.19 \\
P<0.0001^{*}\end{array}$ & $\begin{array}{r}0.06 \\
P=0.2240\end{array}$ & $\begin{array}{r}0.13 \\
P=0.0074\end{array}$ & $\begin{array}{r}-0.15 \\
P=0.0029^{*}\end{array}$ & $\begin{array}{r}-0.02 \\
P=0.7562\end{array}$ & $\begin{array}{r}-0.03 \\
P=0.5188\end{array}$ \\
\hline
\end{tabular}


Table 8. Summary of moisture and total selenium concentrations in water, sediment, aquatic foodchain organisms, and surrogate fish species from combined samples collected in seven intensively monitored drains on six sampling dates between April 2006 and October 2008.

$[\mathrm{N}$, number of samples. Se, total selenium; $\mu \mathrm{g} / \mathrm{L}$, microgram per liter; $\mu \mathrm{g} / \mathrm{g}$, microgram per gram; $\mathrm{n} / \mathrm{a}$, not applicable; ---, not measured]

\begin{tabular}{|c|c|c|c|c|c|}
\hline \multirow[b]{2}{*}{ Matrix } & \multirow[b]{2}{*}{$\mathbf{N}$} & \multicolumn{2}{|c|}{ Moisture (percent) } & \multicolumn{2}{|c|}{ Se ( $\mu g / L$ or $\mu g / g$ dry weight) } \\
\hline & & $\begin{array}{c}\text { Angular } \\
\text { transformed } \\
\text { mean }\end{array}$ & Range & $\begin{array}{c}\text { Geometric } \\
\text { mean }\end{array}$ & Range \\
\hline Filtered water & 91 & $\mathrm{n} / \mathrm{a}$ & $\mathrm{n} / \mathrm{a}$ & 5.62 & $0.700--32.8$ \\
\hline Sediment & 56 & 50.3 & $22.3-77.9$ & 1.43 & $0.330-10.0$ \\
\hline Particulate organic detritus & 126 & 79.0 & $66.8-87.9$ & 5.48 & $0.850-58.0$ \\
\hline Filamentous algae & 125 & 70.4 & $45.7-90.5$ & 2.22 & $0.750-8.26$ \\
\hline Net plankton & 126 & --- & --- & 2.42 & $0.150-19.3$ \\
\hline Midge larvae & 117 & 79.1 & $52.8-87.9$ & 6.50 & $1.39-50.6$ \\
\hline Western mosquitofish & 118 & 77.2 & 71.3-81.3 & 6.81 & $3.66-20.2$ \\
\hline Sailfin molly & 117 & 76.1 & $70.3-81.5$ & 6.89 & $3.09-30.4$ \\
\hline
\end{tabular}


Table 9. Results of two-way analysis of variance, as F-values and significance levels, for selenium concentrations in water, sediment, selected food-chain matrices, and two surrogate fish species sampled from seven intensively monitored agricultural drains on six sampling dates between April 2006 and October 2008.

\begin{tabular}{|c|c|c|c|c|c|}
\hline \multirow{2}{*}{ Matrix } & \multirow{2}{*}{ Source } & \multicolumn{4}{|c|}{ Significance levels } \\
\hline & & $\overline{D F}$ & MS & $\mathbf{F}$ & $\mathbf{P}$ \\
\hline \multirow[t]{4}{*}{ Filtered water } & Drain & 6 & 1.6029 & 5101.67 & $<0.0001$ \\
\hline & Date & 5 & 0.1063 & 338.36 & $<0.0001$ \\
\hline & Interaction & 30 & 0.1177 & 374.51 & $<0.0001$ \\
\hline & Error & 49 & 0.0003 & & \\
\hline \multirow[t]{4}{*}{ Sediment } & Drain & 6 & 0.9549 & 4970.49 & $<0.0001$ \\
\hline & Date & 5 & 0.0205 & 106.80 & $<0.0001$ \\
\hline & Interaction & 30 & 0.0227 & 118.37 & $<0.0001$ \\
\hline & Error & 14 & 0.0002 & & \\
\hline \multirow[t]{4}{*}{ Particulate ordanic detritus } & Drain & 6 & 1.3726 & 77.02 & $<0.0001$ \\
\hline & Date & 5 & 0.2460 & 13.80 & $<0.0001$ \\
\hline & Interaction & 30 & 0.0611 & 3.43 & $<0.0001$ \\
\hline & Error & 84 & 0.0178 & & \\
\hline \multirow[t]{4}{*}{ Filamentous alaae } & Drain & 6 & 0.4401 & 424.49 & $<0.0001$ \\
\hline & Date & 5 & 0.4085 & 394.02 & $<0.0001$ \\
\hline & Interaction & 30 & 0.1088 & 104.89 & $<0.0001$ \\
\hline & Error & 83 & 0.0010 & & \\
\hline \multirow[t]{4}{*}{ Net plankton } & Drain & 6 & 0.9943 & 60.36 & $<0.0001$ \\
\hline & Date & 5 & 0.2866 & 17.40 & $<0.0001$ \\
\hline & Interaction & 30 & 0.2098 & 12.74 & $<0.0001$ \\
\hline & Error & 84 & 0.0165 & & \\
\hline \multirow[t]{4}{*}{ Midae larvae } & Drain & 6 & 1.1083 & 499.15 & $<0.0001$ \\
\hline & Date & 5 & 0.2075 & 93.47 & $<0.0001$ \\
\hline & Interaction & 29 & 0.0801 & 36.08 & $<0.0001$ \\
\hline & Error & 76 & 0.0022 & & \\
\hline \multirow[t]{4}{*}{ Western mosauitofish } & Drain & 6 & 0.5172 & 228.84 & $<0.0001$ \\
\hline & Date & 5 & 0.0534 & 23.65 & $<0.0001$ \\
\hline & Interaction & 29 & 0.0212 & 9.38 & $<0.0001$ \\
\hline & Error & 77 & 0.0023 & & \\
\hline \multirow[t]{4}{*}{ Sailfin mollv } & Drain & 6 & 0.9585 & 671.89 & $<0.0001$ \\
\hline & Date & 5 & 0.1328 & 93.10 & $<0.0001$ \\
\hline & Interaction & 30 & 0.0388 & 27.18 & $<0.0001$ \\
\hline & Error & 75 & 0.0014 & & \\
\hline
\end{tabular}


Table 10. Temporal variations in total dissolved selenium concentration of filtered water samples collected on six sampling dates from seven intensively monitored drains.

Names of drains are shown in table 1. ANOVA, analysis of variance. Within a column, least squares means followed by the same capital letters are not significantly different $(\mathrm{P}>0.05)$ according to Tukey's studentized range test. ID, identification code; $\mathrm{P}$, level of significance; $<$, less than]

\begin{tabular}{|c|c|c|c|c|c|c|c|}
\hline \multirow{2}{*}{$\begin{array}{l}\text { Date or } \\
\text { ANOVA }\end{array}$} & \multicolumn{7}{|c|}{ Total dissolved selenium concentrations, in micrograms per liter, by drain } \\
\hline & TR20 & POED & TR18 & TR14 & 0000 & TTTT & ZSPL \\
\hline $\begin{array}{l}\text { April } \\
2006\end{array}$ & $5.74 \mathrm{~A}$ & $6.80 \mathrm{D}$ & $31.5 \mathrm{~A}$ & $9.35 \mathrm{~B}$ & $3.53 \mathrm{C}$ & $6.55 \mathrm{~A}$ & $4.81 \mathrm{~A}$ \\
\hline $\begin{array}{l}\text { October } \\
2006\end{array}$ & $5.02 \mathrm{~A}$ & $21.4 \mathrm{~A}$ & $19.1 \mathrm{C}$ & $6.16 \mathrm{D}$ & $3.65 \mathrm{BC}$ & $0.900 \mathrm{D}$ & $4.81 \mathrm{~A}$ \\
\hline $\begin{array}{l}\text { April } \\
2007\end{array}$ & $5.86 \mathrm{~A}$ & $9.47 \mathrm{BC}$ & $23.9 \mathrm{~B}$ & $2.17 \mathrm{~F}$ & 4.05 BC & $1.07 \mathrm{C}$ & $3.19 \mathrm{~B}$ \\
\hline $\begin{array}{l}\text { October } \\
2007\end{array}$ & $4.17 \mathrm{~B}$ & $5.45 \mathrm{E}$ & $16.7 \mathrm{CD}$ & $18.8 \mathrm{~A}$ & $9.61 \mathrm{~A}$ & $0.767 \mathrm{D}$ & $4.40 \mathrm{~A}$ \\
\hline $\begin{array}{l}\text { April } \\
2008\end{array}$ & $2.02 \mathrm{C}$ & $8.41 \mathrm{C}$ & $29.6 \mathrm{~A}$ & $3.52 \mathrm{E}$ & $4.13 \mathrm{~B}$ & $1.82 \mathrm{~B}$ & $5.15 \mathrm{~A}$ \\
\hline $\begin{array}{c}\text { October } \\
2008\end{array}$ & $2.11 \mathrm{C}$ & $10.1 \mathrm{~B}$ & $14.8 \mathrm{D}$ & $7.94 \mathrm{C}$ & $4.21 \mathrm{~B}$ & $1.56 \mathrm{~B}$ & $4.39 \mathrm{~A}$ \\
\hline ANOVA & $\begin{array}{c}F_{5,49}=304.08 \\
P<0.0001\end{array}$ & $\begin{array}{c}F_{5,49}=273.96 \\
P<0.0001\end{array}$ & $\begin{array}{c}F_{5,49}=129.31 \\
P<0.0001\end{array}$ & $\begin{array}{c}F_{5,49}=708.41 \\
P<0.0001\end{array}$ & $\begin{array}{c}F_{5,49}=175.35 \\
P<0.0001\end{array}$ & $\begin{array}{c}F_{5,49}=958.87 \\
P<0.0001\end{array}$ & $\begin{array}{c}F_{5,49}=35.42 \\
P<0.0001\end{array}$ \\
\hline
\end{tabular}


Table 11. Spatial variations in total dissolved selenium concentration of filtered water samples collected from seven intensively monitored drains on six sampling dates.

[Names of drains are shown in table 1. ANOVA, analysis of variance. Within a column, least squares means followed by the same capital letters are not significantly different $(\mathrm{P}>0.05)$ according to Tukey's studentized range test . P, level of significance; <, less than]

\begin{tabular}{|c|c|c|c|c|c|c|}
\hline \multirow{2}{*}{$\begin{array}{l}\text { Drain or } \\
\text { ANOVA }\end{array}$} & \multicolumn{6}{|c|}{ Total dissolved selenium concentrations, in micrograms per liter, by sampling dates } \\
\hline & April 2006 & October 2006 & April 2007 & October 2007 & April 2008 & October 2008 \\
\hline TR20 & $5.74 \mathrm{D}$ & $5.02 \mathrm{C}$ & $5.86 \mathrm{C}$ & $4.17 \mathrm{D}$ & $2.02 \mathrm{E}$ & $2.11 \mathrm{E}$ \\
\hline POED & $6.80 \mathrm{C}$ & $21.4 \mathrm{~A}$ & $9.47 \mathrm{~B}$ & $5.45 \mathrm{C}$ & $8.41 \mathrm{~B}$ & $10.1 \mathrm{~B}$ \\
\hline TR18 & $31.5 \mathrm{~A}$ & $19.1 \mathrm{~A}$ & $23.9 \mathrm{~A}$ & $16.7 \mathrm{~A}$ & $29.6 \mathrm{~A}$ & $14.8 \mathrm{~A}$ \\
\hline TR14 & $9.35 \mathrm{~B}$ & $6.16 \mathrm{~B}$ & $2.17 \mathrm{~F}$ & $18.8 \mathrm{~A}$ & $3.52 \mathrm{D}$ & $7.94 \mathrm{C}$ \\
\hline 0000 & $3.53 \mathrm{~F}$ & $3.65 \mathrm{D}$ & $4.05 \mathrm{D}$ & $9.61 \mathrm{~B}$ & $4.13 \mathrm{D}$ & $4.21 \mathrm{D}$ \\
\hline TTTT & $6.55 \mathrm{CD}$ & $0.900 \mathrm{E}$ & $1.07 \mathrm{G}$ & $0.767 \mathrm{E}$ & $1.82 \mathrm{E}$ & $1.56 \mathrm{~F}$ \\
\hline ZSPL & $4.81 \mathrm{E}$ & $4.81 \mathrm{C}$ & $3.19 \mathrm{E}$ & $4.40 \mathrm{D}$ & $5.15 \mathrm{C}$ & $4.39 \mathrm{D}$ \\
\hline ANOVA & $\begin{array}{c}F_{6,49}=891.82 \\
P<0.0001\end{array}$ & $\begin{array}{c}F_{6,49}=1375.46 \\
P<0.0001\end{array}$ & $\begin{array}{c}F_{6,49}=1228.18 \\
P<0.0001\end{array}$ & $\begin{array}{c}F_{6,49}=1409.02 \\
P<0.0001\end{array}$ & $\begin{array}{c}F_{6,49}=1086.99 \\
P<0.0001\end{array}$ & $\begin{array}{c}F_{6,49}=806.76 \\
P<0.0001\end{array}$ \\
\hline
\end{tabular}


Table 12. Temporal variations in total selenium concentration of sediment samples collected on six sampling dates from seven intensively monitored drains.

Names of drains are shown in table 1. ANOVA, analysis of variance. Within a column, least squares means followed by the same capital letters are not significantly different $(\mathrm{P}>0.05)$ according to Tukey's studentized range test. $\mathrm{P}$, level of significance; $>$, greater than; $<$, less than]

\begin{tabular}{|c|c|c|c|c|c|c|c|}
\hline \multirow{2}{*}{$\begin{array}{l}\text { Date or } \\
\text { ANOVA }\end{array}$} & \multicolumn{7}{|c|}{ Total selenium concentration, in micrograms per gram dry weight, by drain } \\
\hline & TR20 & POED & TR18 & TR14 & 0000 & TTTT & ZSPL \\
\hline April 2006 & $1.47 \mathrm{~B}$ & $0.450 \mathrm{~B}$ & $5.42 \mathrm{D}$ & $2.19 \mathrm{BC}$ & $1.23 \mathrm{~A}$ & $0.873 \mathrm{~B}$ & $2.63 \mathrm{~A}$ \\
\hline $\begin{array}{l}\text { October } \\
2006\end{array}$ & $1.64 \mathrm{AB}$ & $0.620 \mathrm{~A}$ & $4.67 \mathrm{D}$ & $1.91 \mathrm{C}$ & $1.02 \mathrm{~B}$ & $1.11 \mathrm{~A}$ & $2.23 \mathrm{~A}$ \\
\hline April 2007 & $2.03 \mathrm{~A}$ & $0.570 \mathrm{~A}$ & $7.02 \mathrm{C}$ & $1.33 \mathrm{D}$ & $0.870 \mathrm{~B}$ & $0.790 \mathrm{BC}$ & $1.42 \mathrm{~B}$ \\
\hline $\begin{array}{l}\text { October } \\
2007\end{array}$ & $1.39 \mathrm{~B}$ & $0.330 \mathrm{C}$ & $7.28 \mathrm{BC}$ & $2.40 \mathrm{~B}$ & $0.970 \mathrm{~B}$ & $0.470 \mathrm{D}$ & $1.44 \mathrm{~B}$ \\
\hline April 2008 & $1.35 \mathrm{BC}$ & $0.410 \mathrm{BC}$ & $8.93 \mathrm{AB}$ & $3.31 \mathrm{~A}$ & $0.970 \mathrm{~B}$ & $0.760 \mathrm{BC}$ & $0.830 \mathrm{C}$ \\
\hline $\begin{array}{l}\text { October } \\
2008\end{array}$ & $1.10 \mathrm{C}$ & $0.420 \mathrm{~B}$ & $10.0 \mathrm{~A}$ & $1.90 \mathrm{C}$ & $0.840 \mathrm{~B}$ & $0.720 \mathrm{C}$ & $0.650 \mathrm{D}$ \\
\hline ANOVA & $\begin{array}{c}F_{5,14}=41.36 \\
P<0.0001\end{array}$ & $\begin{array}{c}F_{5,14}=52.49 \\
P<0.0001\end{array}$ & $\begin{array}{c}F_{5,14}=100.85 \\
P<0.0001\end{array}$ & $\begin{array}{c}F_{5,14}=89.71 \\
P<0.0001\end{array}$ & $\begin{array}{c}F_{5,14}=33.06 \\
P<0.0001\end{array}$ & $\begin{array}{c}F_{5,14}=83.56 \\
P<0.0001\end{array}$ & $\begin{array}{c}F_{5,14}=415.98 \\
P<0.0001\end{array}$ \\
\hline
\end{tabular}


Table 13. Spatial variations in total selenium concentration of sediment samples collected from seven intensively monitored drains on six sampling dates.

[Names of drains are shown in table 1. ANOVA, analysis of variance. Within a column, least squares means followed by the same capital letters are not significantly different $(\mathrm{P}>0.05)$ according to Tukey's studentized range test. $\mathrm{P}$, level of significance; $>$, greater than; $<$, less than]

\begin{tabular}{ccccccc}
\hline & \multicolumn{5}{c}{ Total selenium concentration, in micrograms per gram dry weight, by sampling date } \\
\cline { 2 - 7 } Drain or ANOVA & April 2006 & October 2006 & April 2007 & October 2007 & April 2008 & October 2008 \\
\hline TR20 & $1.47 \mathrm{D}$ & $1.64 \mathrm{C}$ & $2.03 \mathrm{~B}$ & $1.39 \mathrm{CD}$ & $1.35 \mathrm{C}$ & $1.10 \mathrm{C}$ \\
POED & $0.450 \mathrm{G}$ & $0.620 \mathrm{E}$ & $0.570 \mathrm{E}$ & $0.330 \mathrm{G}$ & $0.410 \mathrm{~F}$ & $0.420 \mathrm{~F}$ \\
TR18 & $5.42 \mathrm{~A}$ & $4.67 \mathrm{~A}$ & $7.02 \mathrm{~A}$ & $7.28 \mathrm{~A}$ & $8.93 \mathrm{~A}$ & $10.0 \mathrm{~A}$ \\
TR14 & $2.19 \mathrm{C}$ & $1.91 \mathrm{BC}$ & $1.33 \mathrm{C}$ & $2.40 \mathrm{~B}$ & $3.31 \mathrm{~B}$ & $1.90 \mathrm{~B}$ \\
O000 & $0.816 \mathrm{~F}$ & $1.02 \mathrm{D}$ & $0.870 \mathrm{D}$ & $0.970 \mathrm{E}$ & $0.970 \mathrm{D}$ & $0.840 \mathrm{D}$ \\
TTTT & $0.873 \mathrm{E}$ & $1.11 \mathrm{D}$ & $0.790 \mathrm{D}$ & $0.470 \mathrm{~F}$ & $0.760 \mathrm{E}$ & $0.720 \mathrm{DE}$ \\
ZSPL & $2.63 \mathrm{~B}$ & $2.23 \mathrm{~B}$ & $1.42 \mathrm{C}$ & $1.44 \mathrm{C}$ & $0.830 \mathrm{DE}$ & $0.650 \mathrm{E}$ \\
\hline \multirow{2}{*}{ ANOVA } & $\mathrm{F}_{6,14}=1905.27$ & $\mathrm{~F}_{6,14}=412.53$ & $\mathrm{~F}_{6,14}=671.15$ & $\mathrm{~F}_{6,14}=1039.86$ & $\mathrm{~F}_{6,14}=1057.73$ & $\mathrm{~F}_{6,14}=1076.74$ \\
& $\mathrm{P}<0.0001$ & $\mathrm{P}<0.0001$ & $\mathrm{P}<0.0001$ & $\mathrm{P}<0.0001$ & $\mathrm{P}<0.0001$ & $\mathrm{P}<0.0001$ \\
\hline
\end{tabular}


Table 14. Temporal variations in total selenium concentration of particulate organic detritus samples collected on six sampling dates from seven intensively monitored drains.

[Names of drains are shown in table 1. ANOVA, analysis of variance. Within a column, least squares means followed by the same capital letters are not significantly different $(\mathrm{P}>0.05)$ according to Tukey's studentized range test. $\mathrm{P}$, level of significance; $>$, greater than; $<$, less than]

\begin{tabular}{|c|c|c|c|c|c|c|c|}
\hline \multirow{2}{*}{ Date or ANOVA } & \multicolumn{7}{|c|}{ Total selenium concentration, in micrograms per gram dry weight, by drain } \\
\hline & TR20 & POED & TR18 & TR14 & 0000 & TTTT & ZSPL \\
\hline April 2006 & $6.25 \mathrm{AB}$ & $7.91 \mathrm{~A}$ & $8.63 \mathrm{C}$ & $8.31 \mathrm{~A}$ & $7.17 \mathrm{~A}$ & $3.61 \mathrm{~A}$ & $3.88 \mathrm{~A}$ \\
\hline October 2006 & $5.14 \mathrm{ABC}$ & $10.1 \mathrm{~A}$ & $15.7 \mathrm{ABC}$ & $3.77 \mathrm{~A}$ & $7.87 \mathrm{~A}$ & $1.90 \mathrm{AB}$ & $3.28 \mathrm{~A}$ \\
\hline April 2007 & $8.19 \mathrm{~A}$ & $10.3 \mathrm{~A}$ & $26.2 \mathrm{AB}$ & $6.64 \mathrm{~A}$ & $7.52 \mathrm{~A}$ & $2.67 \mathrm{AB}$ & $4.18 \mathrm{~A}$ \\
\hline October 2007 & $2.21 \mathrm{C}$ & $3.91 \mathrm{~A}$ & $16.8 \mathrm{AC}$ & $4.57 \mathrm{~A}$ & $3.75 \mathrm{~A}$ & $1.18 \mathrm{~B}$ & $3.52 \mathrm{~A}$ \\
\hline April 2008 & $2.56 \mathrm{BC}$ & $7.28 \mathrm{~A}$ & $10.1 \mathrm{BC}$ & $4.64 \mathrm{~A}$ & $4.51 \mathrm{~A}$ & $1.97 \mathrm{AB}$ & $5.04 \mathrm{~A}$ \\
\hline October 2008 & $5.84 \mathrm{AB}$ & $6.92 \mathrm{~A}$ & $39.8 \mathrm{~A}$ & $6.88 \mathrm{~A}$ & $4.92 \mathrm{~A}$ & $2.15 \mathrm{AB}$ & $3.55 \mathrm{~A}$ \\
\hline ANOVA & $\begin{array}{l}F_{5,84}=8.74 \\
P<0.0001\end{array}$ & $\begin{array}{l}F_{5,84}=3.93 \\
P=0.0030\end{array}$ & $\begin{array}{c}F_{5,84}=10.50 \\
P<0.0001\end{array}$ & $\begin{array}{l}F_{5,84}=2.93 \\
P=0.0173\end{array}$ & $\begin{array}{l}F_{5,84}=3.08 \\
P=0.0133\end{array}$ & $\begin{array}{l}F_{5,84}=4.45 \\
P=0.0012\end{array}$ & $\begin{array}{l}F_{5,84}=0.76 \\
P=0.5847\end{array}$ \\
\hline
\end{tabular}


Table 15. Spatial variations in total selenium concentration of particulate organic detritus samples collected from seven intensively monitored drains on six sampling dates.

[Names of drains are shown in table 1. ANOVA, analysis of variance. Within a column, least squares means followed by the same capital letters are not significantly different $(\mathrm{P}>0.05)$ according to Tukey's studentized range test. $\mathrm{P}$, level of significance; $>$, greater than; $<$, less than]

\begin{tabular}{ccccccc}
\hline & \multicolumn{5}{c}{ Total selenium concentrations, in micrograms per gram dry weight, by sampling date } \\
\cline { 2 - 7 } Drain or ANOVA & April 2006 & October 2006 & April 2007 & October 2007 & April 2008 & October 2008 \\
\hline TR20 & $6.25 \mathrm{~A}$ & $5.14 \mathrm{BCD}$ & $8.19 \mathrm{~B}$ & $2.21 \mathrm{BC}$ & $2.56 \mathrm{~B}$ & $5.84 \mathrm{BC}$ \\
POED & $7.91 \mathrm{~A}$ & $10.1 \mathrm{AB}$ & $10.3 \mathrm{AB}$ & $3.91 \mathrm{~B}$ & $7.28 \mathrm{~A}$ & $6.92 \mathrm{~B}$ \\
TR18 & $8.63 \mathrm{~A}$ & $15.7 \mathrm{~A}$ & $26.2 \mathrm{~A}$ & $16.8 \mathrm{~A}$ & $10.1 \mathrm{~A}$ & $39.8 \mathrm{~A}$ \\
TR14 & $8.31 \mathrm{~A}$ & $3.77 \mathrm{BCD}$ & $6.64 \mathrm{BC}$ & $4.57 \mathrm{~B}$ & $4.64 \mathrm{AB}$ & $6.88 \mathrm{~B}$ \\
O000 & $7.17 \mathrm{~A}$ & $7.87 \mathrm{ABC}$ & $7.52 \mathrm{~B}$ & $3.75 \mathrm{~B}$ & $4.51 \mathrm{AB}$ & $4.92 \mathrm{BC}$ \\
TTTT & $3.61 \mathrm{~A}$ & $1.90 \mathrm{D}$ & $2.67 \mathrm{C}$ & $1.18 \mathrm{C}$ & $1.97 \mathrm{~B}$ & $2.15 \mathrm{C}$ \\
ZSPL & $3.88 \mathrm{~A}$ & $3.28 \mathrm{CD}$ & $4.18 \mathrm{BC}$ & $3.52 \mathrm{~B}$ & $5.04 \mathrm{AB}$ & $3.55 \mathrm{BC}$ \\
\hline ANOVA & $\mathrm{F}_{6,84}=4.17$ & $\mathrm{~F}_{6,84}=16.61$ & $\mathrm{~F}_{6,84}=16.40$ & $\mathrm{~F}_{6,84}=20.70$ & $\mathrm{~F}_{6,84}=10.02$ & $\mathrm{~F}_{6,84}=26.27$ \\
& $\mathrm{P}=0.0010$ & $\mathrm{P}<0.0001$ & $\mathrm{P}<0.0001$ & $\mathrm{P}<0.0001$ & $\mathrm{P}<0.0001$ & $\mathrm{P}<0.0001$ \\
\hline
\end{tabular}


Table 16. Temporal variations in total selenium concentration of filamentous algae samples collected on six sampling dates from seven intensively monitored drains.

[Names of drains are shown in table 1. ANOVA, analysis of variance. Within a column, least squares means followed by the same capital letters are not significantly different $(\mathrm{P}>0.05)$ according to Tukey's studentized range test. $\mathrm{P}$, level of significance; $>$, greater than; $<$, less than]

\begin{tabular}{|c|c|c|c|c|c|c|c|}
\hline \multirow{2}{*}{$\begin{array}{l}\text { Date or } \\
\text { ANOVA }\end{array}$} & \multicolumn{7}{|c|}{ Total selenium concentrations, in microgram per gram dry weight, by drain } \\
\hline & TR20 & POED & TR18 & TR14 & 0000 & TTTT & ZSPL \\
\hline April 2006 & $1.59 \mathrm{~B}$ & $1.37 \mathrm{C}$ & $5.91 \mathrm{BC}$ & $1.99 \mathrm{BC}$ & $1.49 \mathrm{C}$ & $2.33 \mathrm{~B}$ & $1.66 \mathrm{~B}$ \\
\hline October 2006 & $3.10 \mathrm{~A}$ & $2.96 \mathrm{~A}$ & $7.22 A B$ & $2.39 \mathrm{~B}$ & $2.36 \mathrm{~B}$ & $2.22 \mathrm{~B}$ & $1.64 \mathrm{~B}$ \\
\hline April 2007 & $1.67 \mathrm{~B}$ & $0.990 \mathrm{D}$ & $5.59 \mathrm{C}$ & $2.35 \mathrm{BC}$ & $1.73 \mathrm{C}$ & $2.35 \mathrm{~B}$ & $1.51 \mathrm{~B}$ \\
\hline October 2007 & $2.48 \mathrm{~A}$ & $1.33 \mathrm{C}$ & $5.85 \mathrm{BC}$ & $3.30 \mathrm{~A}$ & $3.18 \mathrm{~A}$ & $0.960 \mathrm{C}$ & $3.77 \mathrm{~A}$ \\
\hline April 2008 & $1.62 \mathrm{~B}$ & $0.767 \mathrm{E}$ & $0.860 \mathrm{D}$ & $0.970 \mathrm{D}$ & $3.29 \mathrm{~A}$ & $0.933 \mathrm{C}$ & $1.67 \mathrm{~B}$ \\
\hline October 2008 & $2.74 \mathrm{~A}$ & $2.29 \mathrm{~B}$ & $8.05 \mathrm{~A}$ & $1.86 \mathrm{C}$ & $3.37 \mathrm{~A}$ & $5.43 \mathrm{~A}$ & $1.65 B$ \\
\hline ANOVA & $\begin{array}{c}F_{5,83}=48.91 \\
P<0.0001\end{array}$ & $\begin{array}{c}F_{5,83}=139.85 \\
P<0.0001\end{array}$ & $\begin{array}{c}F_{5,83}=380.46 \\
P<0.0001\end{array}$ & $\begin{array}{c}F_{5,83}=91.52 \\
P<0.0001\end{array}$ & $\begin{array}{c}F_{5,83}=68.31 \\
P<0.0001\end{array}$ & $\begin{array}{c}F_{5,83}=237.65 \\
P<0.0001\end{array}$ & $\begin{array}{c}F_{5,83}=64.41 \\
P<0.0001\end{array}$ \\
\hline
\end{tabular}


Table 17. Spatial variations in total selenium concentration of filamentous algae samples collected from seven intensively monitored drains on six sampling dates.

[Names of drains are shown in table 1. ANOVA, analysis of variance. Within a column, least squares means followed by the same capital letters are not significantly different $(\mathrm{P}>0.05)$ according to Tukey's studentized range test. $\mathrm{P}$, level of significance; $>$, greater than; $<$, less than]

\begin{tabular}{|c|c|c|c|c|c|c|}
\hline \multirow{2}{*}{ Drain or ANOVA } & \multicolumn{6}{|c|}{ Total selenium concentrations, in micrograms per gram dry weight, by sampling date } \\
\hline & April 2006 & October 2006 & April 2007 & October 2007 & April 2008 & October 2008 \\
\hline TR20 & $1.59 \mathrm{CD}$ & $3.10 \mathrm{~B}$ & $1.67 \mathrm{C}$ & $2.48 \mathrm{C}$ & $1.62 \mathrm{~B}$ & $2.74 \mathrm{CD}$ \\
\hline POED & $1.37 \mathrm{D}$ & $2.96 \mathrm{BC}$ & $0.990 \mathrm{D}$ & $1.33 \mathrm{D}$ & $0.767 \mathrm{C}$ & 2.29 DE \\
\hline TR18 & $5.91 \mathrm{~A}$ & $7.22 \mathrm{~A}$ & $5.59 \mathrm{~A}$ & $5.85 \mathrm{~A}$ & $0.860 \mathrm{C}$ & $8.05 \mathrm{~A}$ \\
\hline TR14 & $1.99 \mathrm{BC}$ & $2.39 \mathrm{CD}$ & $2.35 \mathrm{~B}$ & $3.30 \mathrm{~B}$ & $0.970 \mathrm{C}$ & $1.86 \mathrm{EF}$ \\
\hline 0000 & $1.49 \mathrm{D}$ & $2.36 \mathrm{CD}$ & $1.73 \mathrm{C}$ & $3.18 \mathrm{~B}$ & $3.29 \mathrm{~A}$ & $3.37 \mathrm{C}$ \\
\hline TTTT & $2.33 \mathrm{~B}$ & $2.22 \mathrm{D}$ & $2.35 \mathrm{~B}$ & $0.960 \mathrm{E}$ & $0.933 \mathrm{C}$ & $5.43 \mathrm{~B}$ \\
\hline ZSPL & $1.66 \mathrm{CD}$ & $1.64 \mathrm{E}$ & $1.51 \mathrm{C}$ & $3.77 \mathrm{~B}$ & $1.67 \mathrm{~B}$ & $1.65 \mathrm{~F}$ \\
\hline \multirow{2}{*}{ ANOVA } & $F_{6,83}=137.54$ & $F_{6,83}=109.19$ & $F_{6,83}=157.71$ & $\mathrm{~F}_{6,83}=212.65$ & $F_{6,83}=146.92$ & $F_{6,83}=181.56$ \\
\hline & $P=0.0010$ & $P<0.0001$ & $P<0.0001$ & $P<0.0001$ & $P<0.0001$ & $P<0.0001$ \\
\hline
\end{tabular}


Table 18. Temporal variations in total selenium concentration of net plankton samples collected on six sampling dates from seven intensively monitored drains.

[Names of drains are shown in table 1. ANOVA, analysis of variance. Within a column, least squares means followed by the same capital letters are not significantly different $(\mathrm{P}>0.05)$ according to Tukey's studentized range test. $\mathrm{P}$, level of significance; $>$, greater than; $<$, less than]

\begin{tabular}{|c|c|c|c|c|c|c|c|}
\hline \multirow{2}{*}{$\begin{array}{l}\text { Date or } \\
\text { ANOVA }\end{array}$} & \multicolumn{7}{|c|}{ Total selenium concentrations, in micrograms per gram dry weight, by drain } \\
\hline & TR20 & POED & TR18 & TR14 & 0000 & TTTT & ZSPL \\
\hline April 2006 & $1.69 \mathrm{~A}$ & $0.847 \mathrm{~B}$ & $4.67 \mathrm{~B}$ & $10.0 \mathrm{~A}$ & $2.28 \mathrm{~A}$ & $2.38 \mathrm{AB}$ & $2.72 \mathrm{~A}$ \\
\hline October 2006 & $3.27 \mathrm{~A}$ & $3.49 \mathrm{~A}$ & $5.12 \mathrm{~B}$ & $2.90 \mathrm{~B}$ & $2.40 \mathrm{~A}$ & $3.36 \mathrm{~A}$ & $2.20 \mathrm{~A}$ \\
\hline April 2007 & $2.74 \mathrm{~A}$ & $1.83 \mathrm{AB}$ & $14.6 \mathrm{~A}$ & $4.33 \mathrm{AB}$ & $2.10 \mathrm{~A}$ & 2.17 AB & $2.69 \mathrm{~A}$ \\
\hline October 2007 & $1.91 \mathrm{~A}$ & $0.168 \mathrm{C}$ & $16.5 \mathrm{~A}$ & $3.75 \mathrm{~B}$ & $2.84 \mathrm{~A}$ & $0.698 \mathrm{C}$ & $0.784 \mathrm{~B}$ \\
\hline April 2008 & $2.95 \mathrm{~A}$ & $1.69 \mathrm{AB}$ & $3.53 \mathrm{~B}$ & $2.51 \mathrm{~B}$ & $1.64 \mathrm{~A}$ & $1.08 \mathrm{BC}$ & $1.85 \mathrm{AB}$ \\
\hline October 2008 & $2.02 \mathrm{~A}$ & $1.08 \mathrm{~B}$ & $2.31 \mathrm{~B}$ & $2.15 B$ & $2.75 \mathrm{~A}$ & $3.08 \mathrm{~A}$ & $2.68 \mathrm{~A}$ \\
\hline ANOVA & $\begin{array}{l}F_{5,84}=2.46 \\
P=0.0395\end{array}$ & $\begin{array}{c}F_{5,84}=36.98 \\
P<0.0001\end{array}$ & $\begin{array}{c}F_{5,84}=21.26 \\
P<0.0001\end{array}$ & $\begin{array}{c}F_{5,84}=10.42 \\
P<0.0001\end{array}$ & $\begin{array}{l}F_{5,84}=1.36 \\
P=0.2469\end{array}$ & $\begin{array}{c}F_{5,84}=13.36 \\
P<0.0001\end{array}$ & $\begin{array}{l}F_{5,84}=7.98 \\
P<0.0001\end{array}$ \\
\hline
\end{tabular}


Table 19. Spatial variations in total selenium concentration of net plankton samples collected from seven intensively monitored drains on six sampling dates.

[Names of drains are shown in table 1. ANOVA, analysis of variance. Within a column, least squares means followed by the same capital letters are not significantly different $(\mathrm{P}>0.05)$ according to Tukey's studentized range test. $\mathrm{P}$, level of significance; >, greater than; <, less than]

\begin{tabular}{|c|c|c|c|c|c|c|}
\hline \multirow{2}{*}{ Drain or ANOVA } & \multicolumn{6}{|c|}{ Total selenium concentrations, in micrograms per gram dry weight, by sampling date } \\
\hline & April 2006 & October 2006 & April 2007 & October 2007 & April 2008 & October 2008 \\
\hline TR20 & $1.69 \mathrm{CD}$ & $3.27 \mathrm{~A}$ & $2.74 \mathrm{~B}$ & $1.91 \mathrm{BC}$ & $2.95 \mathrm{~A}$ & $2.02 A B$ \\
\hline POED & $0.847 \mathrm{D}$ & $3.49 \mathrm{~A}$ & $1.83 \mathrm{~B}$ & $0.168 \mathrm{E}$ & $1.69 \mathrm{AB}$ & $1.08 \mathrm{~B}$ \\
\hline TR18 & 4.67 AB & $5.12 \mathrm{~A}$ & $14.6 \mathrm{~A}$ & $16.5 \mathrm{~A}$ & $3.53 \mathrm{~A}$ & $2.31 A B$ \\
\hline TR14 & $10.0 \mathrm{~A}$ & $2.90 \mathrm{~A}$ & $4.33 \mathrm{~B}$ & $3.75 \mathrm{~B}$ & $2.51 \mathrm{AB}$ & $2.15 A B$ \\
\hline 0000 & $2.28 \mathrm{BC}$ & $2.40 \mathrm{~A}$ & $2.10 \mathrm{~B}$ & $2.84 \mathrm{~B}$ & $1.64 \mathrm{AB}$ & $2.75 \mathrm{AB}$ \\
\hline TTTT & $2.38 \mathrm{BC}$ & $3.36 \mathrm{~A}$ & $2.17 \mathrm{~B}$ & $0.698 \mathrm{D}$ & $1.08 \mathrm{~B}$ & $3.08 \mathrm{~A}$ \\
\hline ZSPL & $2.72 \mathrm{BC}$ & $2.20 \mathrm{~A}$ & $2.69 \mathrm{~B}$ & $0.784 \mathrm{CD}$ & $1.85 \mathrm{AB}$ & $2.68 \mathrm{AB}$ \\
\hline \multirow{2}{*}{ ANOVA } & $F_{6,84}=20.73$ & $F_{6,84}=2.63$ & $F_{6,84}=17.72$ & $F_{6,84}=73.25$ & $F_{6,84}=5.61$ & $F_{6,84}=4.10$ \\
\hline & $P<0.0001$ & $P=0.0220$ & $P<0.0001$ & $P<0.0001$ & $P<0.0001$ & $P=0.0012$ \\
\hline
\end{tabular}


Table 20. Temporal variations in total selenium concentration of midge larvae samples collected on six sampling dates from seven intensively monitored drains.

[Names of drains are shown in table 1. ANOVA, analysis of variance. Within a column, least squares means followed by the same capital letters are not significantly different $(\mathrm{P}>0.05)$ according to Tukey's studentized range test. $\mathrm{P}$, level of significance; $>$, greater than; $<$, less than; ---, not measured]

\begin{tabular}{|c|c|c|c|c|c|c|c|}
\hline Date or ANOVA & TR20 & POED & TR18 & TR14 & 0000 & TTTT & ZSPL \\
\hline April 2006 & $6.17 \mathrm{AB}$ & --- & $28.0 \mathrm{AB}$ & $7.59 \mathrm{AB}$ & $5.55 \mathrm{AB}$ & $6.95 \mathrm{~A}$ & $4.25 \mathrm{~A}$ \\
\hline October 2006 & $8.17 \mathrm{AB}$ & $5.65 B$ & $22.4 \mathrm{~B}$ & $4.80 \mathrm{C}$ & $3.78 \mathrm{BC}$ & $5.93 \mathrm{~A}$ & $3.60 \mathrm{~A}$ \\
\hline April 2007 & $8.69 \mathrm{~A}$ & $4.30 \mathrm{~B}$ & $13.1 \mathrm{C}$ & 7.17 AB & $4.28 \mathrm{AB}$ & $5.05 \mathrm{~A}$ & $3.39 A B$ \\
\hline October 2007 & $1.82 \mathrm{C}$ & $4.01 \mathrm{~B}$ & $14.2 \mathrm{C}$ & $5.37 \mathrm{BC}$ & $3.99 \mathrm{BC}$ & $6.13 \mathrm{~A}$ & $2.50 \mathrm{~B}$ \\
\hline April 2008 & $5.84 \mathrm{~B}$ & $13.6 \mathrm{~A}$ & $42.9 \mathrm{~A}$ & $9.38 \mathrm{~A}$ & $6.05 \mathrm{~A}$ & $2.60 \mathrm{~B}$ & $3.51 \mathrm{AB}$ \\
\hline October 2008 & $6.38 \mathrm{AB}$ & $16.8 \mathrm{~A}$ & $46.2 \mathrm{~A}$ & $7.10 \mathrm{AB}$ & $2.90 \mathrm{C}$ & $6.49 \mathrm{~A}$ & $3.85 \mathrm{~A}$ \\
\hline ANOVA & $\begin{array}{c}F_{5,76}=82.76 \\
P<0.0001\end{array}$ & $\begin{array}{c}F_{4,76}=114.02 \\
P<0.0001\end{array}$ & $\begin{array}{c}F_{5,76}=72.30 \\
P<0.0001\end{array}$ & $\begin{array}{c}F_{5,76}=15.12 \\
P<0.0001\end{array}$ & $\begin{array}{c}F_{5,76}=18.06 \\
P<0.0001\end{array}$ & $\begin{array}{c}F_{5,76}=24.44 \\
P<0.0001\end{array}$ & $\begin{array}{l}F_{5,76}=8.26 \\
P<0.0001\end{array}$ \\
\hline
\end{tabular}


Table 21. Spatial variations in total selenium concentration of midge larvae samples collected from seven intensively monitored drains on six sampling dates.

[Names of drains are shown in table 1. ANOVA, analysis of variance. Within a column, least squares means followed by the same capital letters are not significantly different $(\mathrm{P}>0.05)$ according to Tukey's studentized range test. P, level of significance; >, greater than; <, less than: ---, not measured]

\begin{tabular}{ccccccc}
\hline & \multicolumn{5}{c}{ Total selenium concentration, in microgram per gram dry weight, by sampling date } \\
\cline { 2 - 7 } Drain or ANOVA & April 2006 & October 2006 & April 2007 & October 2007 & April 2008 & October 2008 \\
\hline TR20 & $6.17 \mathrm{BC}$ & $8.17 \mathrm{~B}$ & $8.69 \mathrm{~B}$ & $1.82 \mathrm{D}$ & $5.84 \mathrm{D}$ & $6.38 \mathrm{C}$ \\
POED & -- & $5.65 \mathrm{CD}$ & $4.30 \mathrm{DE}$ & $4.01 \mathrm{C}$ & $13.6 \mathrm{~B}$ & $16.8 \mathrm{~B}$ \\
TR18 & $28.0 \mathrm{~A}$ & $22.4 \mathrm{~A}$ & $13.1 \mathrm{~A}$ & $14.2 \mathrm{~A}$ & $42.9 \mathrm{~A}$ & $46.2 \mathrm{~A}$ \\
TR14 & $7.59 \mathrm{~B}$ & $4.80 \mathrm{CDE}$ & $7.17 \mathrm{BC}$ & $5.37 \mathrm{BC}$ & $9.38 \mathrm{C}$ & $7.10 \mathrm{C}$ \\
O000 & $5.55 \mathrm{BC}$ & $3.78 \mathrm{DE}$ & $4.28 \mathrm{DE}$ & $3.99 \mathrm{C}$ & $6.05 \mathrm{D}$ & $2.90 \mathrm{D}$ \\
TTTT & $6.95 \mathrm{~B}$ & $5.93 \mathrm{BC}$ & $5.05 \mathrm{CD}$ & $6.13 \mathrm{~B}$ & $2.60 \mathrm{E}$ & $6.49 \mathrm{C}$ \\
ZSPL & $4.25 \mathrm{C}$ & $3.60 \mathrm{E}$ & $3.39 \mathrm{E}$ & $2.50 \mathrm{D}$ & $3.51 \mathrm{E}$ & $3.85 \mathrm{D}$ \\
\hline \multirow{2}{*}{ ANOVA } & $\mathrm{F}_{5,76=48.12}$ & $\mathrm{~F}_{6,76}=95.46$ & $\mathrm{~F}_{6,76}=57.72$ & $\mathrm{~F}_{6,76}=112.27$ & $\mathrm{~F}_{6,76}=204.60$ & $\mathrm{~F}_{6,76}=224.91$ \\
& $\mathrm{P}<0.0001$ & $\mathrm{P}<0.0001$ & $\mathrm{P}<0.0001$ & $\mathrm{P}<0.0001$ & $\mathrm{P}<0.0001$ & $\mathrm{P}<0.0001$ \\
\hline
\end{tabular}


Table 22. Temporal variations in total selenium concentration of western mosquitofish samples collected on six sampling dates from seven intensively monitored drains.

[Names of drains are shown in table 1. ANOVA, analysis of variance. Within a column, least squares means followed by the same capital letters are not significantly different $(\mathrm{P}>0.05)$ according to Tukey's studentized range test. $\mathrm{P}$, level of significance; $>$, greater than; $<$, less than; ---, not measured]

\begin{tabular}{|c|c|c|c|c|c|c|c|}
\hline \multirow{2}{*}{ Date or ANOVA } & \multicolumn{7}{|c|}{ Total selenium concentration, in micrograms per gram dry weight, by drain } \\
\hline & TR20 & POED & TR18 & TR14 & 0000 & TTTT & ZSPL \\
\hline April 2006 & $6.87 \mathrm{~A}$ & $7.73 \mathrm{BC}$ & $18.3 \mathrm{~A}$ & $7.27 \mathrm{~A}$ & $6.37 \mathrm{AB}$ & $7.87 \mathrm{~A}$ & --- \\
\hline October 2006 & $4.82 \mathrm{AB}$ & $9.97 \mathrm{~B}$ & $14.2 \mathrm{~A}$ & $5.15 A B$ & $7.19 \mathrm{~A}$ & $6.77 \mathrm{~A}$ & $6.69 \mathrm{~A}$ \\
\hline April 2007 & $6.03 \mathrm{AB}$ & $8.86 \mathrm{~B}$ & $18.7 \mathrm{~A}$ & $5.58 \mathrm{AB}$ & $5.63 \mathrm{ABC}$ & $4.70 \mathrm{BC}$ & $5.54 \mathrm{~A}$ \\
\hline October 2007 & $5.07 \mathrm{AB}$ & $5.76 \mathrm{C}$ & $14.1 \mathrm{~A}$ & $5.83 A B$ & $4.46 \mathrm{BC}$ & $3.91 \mathrm{C}$ & $5.76 \mathrm{~A}$ \\
\hline April 2008 & $4.64 \mathrm{~B}$ & $10.4 \mathrm{~B}$ & $16.4 \mathrm{~A}$ & $4.17 \mathrm{~B}$ & $4.21 \mathrm{C}$ & $3.69 \mathrm{C}$ & $5.76 \mathrm{~A}$ \\
\hline October 2008 & $5.80 \mathrm{AB}$ & $14.9 \mathrm{~A}$ & $18.1 \mathrm{~A}$ & $4.30 \mathrm{~B}$ & $4.40 \mathrm{C}$ & $6.13 \mathrm{AB}$ & $6.52 \mathrm{~A}$ \\
\hline ANOVA & $\begin{array}{l}F_{5,77}=5.71 \\
P=0.0002\end{array}$ & $\begin{array}{c}F_{5,77}=25.33 \\
P<0.0001\end{array}$ & $\begin{array}{l}F_{5,77}=3.72 \\
P=0.0045\end{array}$ & $\begin{array}{l}F_{5,77}=6.91 \\
P<0.0001\end{array}$ & $\begin{array}{c}F_{5,77}=12.40 \\
P<0.0001\end{array}$ & $\begin{array}{c}F_{5,77}=23.71 \\
P<0.0001\end{array}$ & $\begin{array}{l}F_{4,77}=1.59 \\
P=0.1852\end{array}$ \\
\hline
\end{tabular}


Table 23. Spatial variations in total selenium concentration of western mosquitofish samples collected from seven intensively monitored drains on six sampling dates.

[Names of drains are shown in table 1. ANOVA, analysis of variance. Within a column, least squares means followed by the same capital letters are not significantly different $(\mathrm{P}>0.05)$ according to Tukey's studentized range test. P, level of significance; >, greater than; <, less than; ---, not measured]

\begin{tabular}{|c|c|c|c|c|c|c|}
\hline \multirow{2}{*}{ Drain or ANOVA } & \multicolumn{6}{|c|}{ Total selenium concentrations, in micrograms per gram dry weight, by sampling date } \\
\hline & April 2006 & October 2006 & April 2007 & October 2007 & April 2008 & October 2008 \\
\hline TR20 & $6.87 \mathrm{~B}$ & $4.82 \mathrm{D}$ & $6.03 \mathrm{C}$ & $5.07 \mathrm{BC}$ & $4.64 \mathrm{CD}$ & $5.80 \mathrm{BC}$ \\
\hline POED & $7.73 \mathrm{~B}$ & $9.97 \mathrm{AB}$ & $8.86 \mathrm{~B}$ & $5.76 \mathrm{~B}$ & $10.4 B$ & $14.9 \mathrm{~A}$ \\
\hline TR18 & $18.3 \mathrm{~A}$ & $14.2 \mathrm{~A}$ & $18.7 \mathrm{~A}$ & $14.1 \mathrm{~A}$ & $16.4 \mathrm{~A}$ & $18.1 \mathrm{~A}$ \\
\hline TR14 & $7.27 \mathrm{~B}$ & $5.15 \mathrm{CD}$ & $5.58 \mathrm{C}$ & $5.83 \mathrm{~B}$ & $4.17 \mathrm{CD}$ & $4.30 \mathrm{C}$ \\
\hline 0000 & $6.37 \mathrm{~B}$ & $7.19 \mathrm{BC}$ & $5.63 \mathrm{C}$ & $4.46 \mathrm{BC}$ & 4.21 CD & $4.40 \mathrm{C}$ \\
\hline TTTT & $7.87 \mathrm{~B}$ & $6.77 \mathrm{CD}$ & $4.70 \mathrm{C}$ & $3.91 \mathrm{C}$ & $3.69 \mathrm{D}$ & $6.13 \mathrm{BC}$ \\
\hline ZSPL & --- & $6.69 \mathrm{CD}$ & $5.54 \mathrm{C}$ & $5.76 \mathrm{~B}$ & $5.76 \mathrm{C}$ & $6.52 \mathrm{~B}$ \\
\hline \multirow{2}{*}{ ANOVA } & $F_{5,77}=15.02$ & $F_{6,77}=35.35$ & $F_{6,77}=55.84$ & $F_{6,77}=43.08$ & $F_{6,77}=78.18$ & $F_{6,77}=82.28$ \\
\hline & $P<0.0001$ & $P<0.0001$ & $P<0.0001$ & $P<0.0001$ & $P<0.0001$ & $P<0.0001$ \\
\hline
\end{tabular}


Table 24. Temporal variations in total selenium concentration of sailfin molly samples collected on six sampling dates from seven intensively monitored drains.

[Names of drains are shown in table 1. ANOVA, analysis of variance. Within a column, least squares means followed by the same capital letters are not significantly different $(\mathrm{P}>0.05)$ according to Tukey's studentized range test. $\mathrm{P}$, level of significance; $>$, greater than; $<$, less than]

\begin{tabular}{|c|c|c|c|c|c|c|c|}
\hline \multirow{2}{*}{ Date or ANOVA } & \multicolumn{7}{|c|}{ Total selenium concentrations, in micrograms per gram dry weight, by drain } \\
\hline & TR20 & POED & TR18 & TR14 & 0000 & TTTT & ZSPL \\
\hline April 2006 & $7.24 \mathrm{~B}$ & $9.34 \mathrm{~B}$ & 18.1 BC & $6.80 \mathrm{~A}$ & $5.36 \mathrm{AB}$ & $5.19 \mathrm{~A}$ & $4.80 \mathrm{~A}$ \\
\hline October 2006 & $15.4 \mathrm{~A}$ & $19.5 \mathrm{~A}$ & $23.3 \mathrm{AB}$ & $4.62 \mathrm{~B}$ & $5.00 \mathrm{~A}$ & $5.45 \mathrm{~A}$ & $4.66 \mathrm{~A}$ \\
\hline April 2007 & $5.11 \mathrm{C}$ & $9.91 \mathrm{~B}$ & $13.5 \mathrm{D}$ & $4.34 \mathrm{~B}$ & $3.85 \mathrm{AB}$ & $4.68 \mathrm{~A}$ & $4.88 \mathrm{~A}$ \\
\hline October 2007 & $4.69 \mathrm{C}$ & $4.86 \mathrm{C}$ & $24.5 \mathrm{~A}$ & $4.31 \mathrm{~B}$ & $4.13 \mathrm{AB}$ & $4.55 \mathrm{~A}$ & $4.55 \mathrm{~A}$ \\
\hline April 2008 & $4.24 \mathrm{C}$ & $5.90 \mathrm{C}$ & $15.9 \mathrm{CD}$ & $3.92 \mathrm{~B}$ & $3.86 \mathrm{AB}$ & $4.73 \mathrm{~A}$ & $5.24 \mathrm{~A}$ \\
\hline October 2008 & $7.47 \mathrm{~B}$ & $16.1 \mathrm{~A}$ & $26.8 \mathrm{~A}$ & $4.68 \mathrm{~B}$ & $3.61 \mathrm{~B}$ & $5.60 \mathrm{~A}$ & $4.66 \mathrm{~A}$ \\
\hline ANOVA & $\begin{array}{c}F_{5,75}=86.64 \\
P<0.0001\end{array}$ & $\begin{array}{c}F_{5,75}=116.99 \\
P<0.0001\end{array}$ & $\begin{array}{c}F_{5,75}=19.13 \\
P<0.0001\end{array}$ & $\begin{array}{c}F_{5,75}=14.53 \\
P<0.0001\end{array}$ & $\begin{array}{l}F_{5,75}=6.58 \\
P<0.0001\end{array}$ & $\begin{array}{l}F_{5,75}=2.89 \\
P=0.0192\end{array}$ & $\begin{array}{l}F_{5,75}=1.00 \\
P=0.4232\end{array}$ \\
\hline
\end{tabular}


Table 25. Spatial variations in total selenium concentration of sailfin molly samples collected from seven intensively monitored drains on six sampling dates.

[Names of drains are shown in table 1. ANOVA, analysis of variance. Within a column, least squares means followed by the same capital letters are not significantly different $(\mathrm{P}>0.05)$ according to Tukey's studentized range test. $\mathrm{P}$, level of significance; >, greater than; <, less than]

\begin{tabular}{|c|c|c|c|c|c|c|}
\hline \multirow{2}{*}{ Drain or ANOVA } & \multicolumn{6}{|c|}{ Total selenium concentrations, in micrograms per gram dry weight, by sampling date } \\
\hline & April 2006 & October 2006 & April 2007 & October 2007 & April 2008 & October 2008 \\
\hline TR20 & $7.24 \mathrm{BC}$ & $15.4 \mathrm{~B}$ & $5.11 \mathrm{C}$ & $4.69 \mathrm{~B}$ & 4.24 BCD & $7.47 \mathrm{C}$ \\
\hline POED & $9.34 \mathrm{~B}$ & $19.5 \mathrm{AB}$ & $9.91 \mathrm{~B}$ & $4.86 \mathrm{~B}$ & $5.90 \mathrm{~B}$ & $16.1 \mathrm{~B}$ \\
\hline TR18 & $18.1 \mathrm{~A}$ & $23.3 \mathrm{~A}$ & $13.5 \mathrm{~A}$ & $24.5 \mathrm{~A}$ & $15.9 \mathrm{~A}$ & $26.8 \mathrm{~A}$ \\
\hline TR14 & $6.80 \mathrm{CD}$ & $4.62 \mathrm{C}$ & $4.34 \mathrm{C}$ & $4.31 \mathrm{~B}$ & $3.92 \mathrm{D}$ & 4.68 DE \\
\hline 0000 & $5.36 \mathrm{CD}$ & $5.00 \mathrm{C}$ & $3.85 \mathrm{C}$ & $4.13 \mathrm{~B}$ & $3.86 \mathrm{D}$ & $3.61 \mathrm{E}$ \\
\hline TTTT & $5.19 \mathrm{D}$ & $5.45 \mathrm{C}$ & $4.68 \mathrm{C}$ & $4.55 \mathrm{~B}$ & $4.73 \mathrm{BCD}$ & $5.60 \mathrm{CD}$ \\
\hline ZSPL & $4.80 \mathrm{D}$ & $4.66 \mathrm{C}$ & $4.88 \mathrm{C}$ & $4.55 \mathrm{~B}$ & $5.24 \mathrm{BC}$ & $4.66 \mathrm{DE}$ \\
\hline \multirow{2}{*}{ ANOVA } & $F_{6,75}=69.42$ & $F_{6,75}=215.59$ & $F_{6,75}=74.45$ & $F_{6,75}=163.25$ & $F_{6,75}=97.03$ & $F_{6,75}=216.46$ \\
\hline & $P<0.0001$ & $P<0.0001$ & $P<0.0001$ & $P<0.0001$ & $P<0.0001$ & $P<0.0001$ \\
\hline
\end{tabular}


Table 26. Pearson product-moment correlation coefficients and $P$ values for total selenium concentrations measured in water, sediment, selected food-chain taxa, and surrogate fish species.

[P values are excluded from autocorrelations (only correlation coefficients are shown). Sample size is 41 for midge larvae and western mosquitofish and 42 for other matrices. P, level of significance]

\begin{tabular}{|c|c|c|c|c|c|c|c|c|}
\hline Variable & $\begin{array}{l}\text { Filtered } \\
\text { water }\end{array}$ & Sediment & Detritus & $\begin{array}{l}\text { Filamentous } \\
\text { algae }\end{array}$ & $\begin{array}{c}\text { Net } \\
\text { plankton }\end{array}$ & $\begin{array}{l}\text { Midge } \\
\text { larvae }\end{array}$ & $\begin{array}{c}\text { Western } \\
\text { mosquitofish }\end{array}$ & $\begin{array}{l}\text { Sailfin } \\
\text { molly }\end{array}$ \\
\hline $\begin{array}{l}\text { Filtered } \\
\text { water }\end{array}$ & 1.00 & $\begin{array}{r}0.51 \\
P=0.0005^{*}\end{array}$ & $\begin{array}{r}0.75 \\
P<0.0001^{*}\end{array}$ & $\begin{array}{r}0.33 \\
P=0.0306\end{array}$ & $\begin{array}{r}0.38 \\
P=0.0143\end{array}$ & $\begin{array}{r}0.55 \\
P=0.0002^{*}\end{array}$ & $\begin{array}{r}0.73 \\
P<0.0001^{*}\end{array}$ & $\begin{array}{r}0.65 \\
P<0.0001^{*}\end{array}$ \\
\hline Sediment & & 1.00 & $\begin{array}{r}0.54 \\
P=0.0002^{*}\end{array}$ & $\begin{array}{r}0.46 \\
P=0.0023\end{array}$ & $\begin{array}{r}0.65 \\
P<0.0001^{*}\end{array}$ & $\begin{array}{r}0.59 \\
P<0.0001^{*}\end{array}$ & $\begin{array}{r}0.50 \\
P=0.0009^{*}\end{array}$ & $\begin{array}{r}0.47 \\
P=0.0018^{*}\end{array}$ \\
\hline Detritus & & & 1.00 & $\begin{array}{r}0.39 \\
P=0.0097\end{array}$ & $\begin{array}{r}0.44 \\
P=0.0036\end{array}$ & $\begin{array}{r}0.65 \\
P<0.0001^{*}\end{array}$ & $\begin{array}{r}0.75 \\
P<0.0001^{*}\end{array}$ & $\begin{array}{r}0.71 \\
P<0.0001^{*}\end{array}$ \\
\hline $\begin{array}{l}\text { Filamentous } \\
\text { algae }\end{array}$ & & & & 1.00 & $\begin{array}{r}0.47 \\
P=0.0017^{\star}\end{array}$ & $\begin{array}{r}0.30 \\
P=0.0590\end{array}$ & $\begin{array}{r}0.39 \\
P=0.0117\end{array}$ & $\begin{array}{r}0.46 \\
P=0.0024\end{array}$ \\
\hline Net plankton & & & & & 1.00 & $\begin{array}{r}0.36 \\
P=0.0196\end{array}$ & $\begin{array}{r}0.39 \\
\mathrm{P}=0.0114\end{array}$ & $\begin{array}{r}0.36 \\
P=0.0195\end{array}$ \\
\hline $\begin{array}{l}\text { Midge } \\
\text { larvae }\end{array}$ & & & & & & 1.00 & $\begin{array}{r}0.77 \\
P<0.0001^{*}\end{array}$ & $\begin{array}{r}0.75 \\
P<0.0001^{*}\end{array}$ \\
\hline $\begin{array}{l}\text { Western } \\
\text { mosquitofish }\end{array}$ & & & & & & & 1.00 & $\begin{array}{r}0.84 \\
P<0.0001^{*}\end{array}$ \\
\hline Sailfin molly & & & & & & & & 1.00 \\
\hline
\end{tabular}


Table 27. Pearson product-moment correlation coefficients and $P$ values for total selenium concentrations in sediments normalized for total organic carbon content ( $\mu \mathrm{g} \mathrm{Se/g} \mathrm{TOC)} \mathrm{and} \mathrm{total} \mathrm{selenium} \mathrm{concentrations} \mathrm{in} \mathrm{filtered}$ water $(\mu \mathrm{g} \mathrm{Se} / \mathrm{L})$, selected food-chain taxa ( $\mu \mathrm{g} \mathrm{Se} / \mathrm{g})$, and surrogate fish species $(\mu \mathrm{g} \mathrm{Se} / \mathrm{g})$.

[Sample size is 41 for midge larvae and western mosquitofish and 42 for other matrices. P, level of significance. TOCnormalized sediment: None of the correlation coefficients are significant according to an adjusted Bonferroni $\mathrm{P}=0.0071$ for 7 simultaneous comparisons]

\begin{tabular}{lr}
\hline Variable & $\begin{array}{c}\text { TOC- } \\
\text { normalized } \\
\text { sediment }\end{array}$ \\
\hline Filtered water & 0.29 \\
Detritus & $\mathrm{P}=0.0667$ \\
& 0.25 \\
Filamentous algae & $\mathrm{P}=0.1155$ \\
& 0.38 \\
Net plankton & $\mathrm{P}=0.0125$ \\
Midge larvae & 0.15 \\
& $\mathrm{P}=0.3463$ \\
Western mosquitofish & 0.24 \\
& $\mathrm{P}=0.1299$ \\
Sailfin molly & 0.16 \\
& $\mathrm{P}=0.3090$ \\
& 0.17 \\
& $\mathrm{P}=0.2772$ \\
\hline
\end{tabular}


Publishing support provided by the U.S. Geological Survey Publishing Network, Tacoma Publishing Service Center

For more information concerning the research in this report, contact the Director, Western Fisheries Research Center

U.S. Geological Survey, 6505 NE 65th Street

Seattle, Washington 98115

http://wfrc.usgs.gov/ 

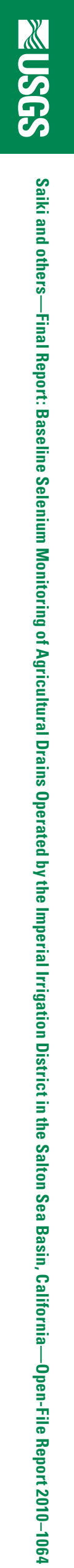